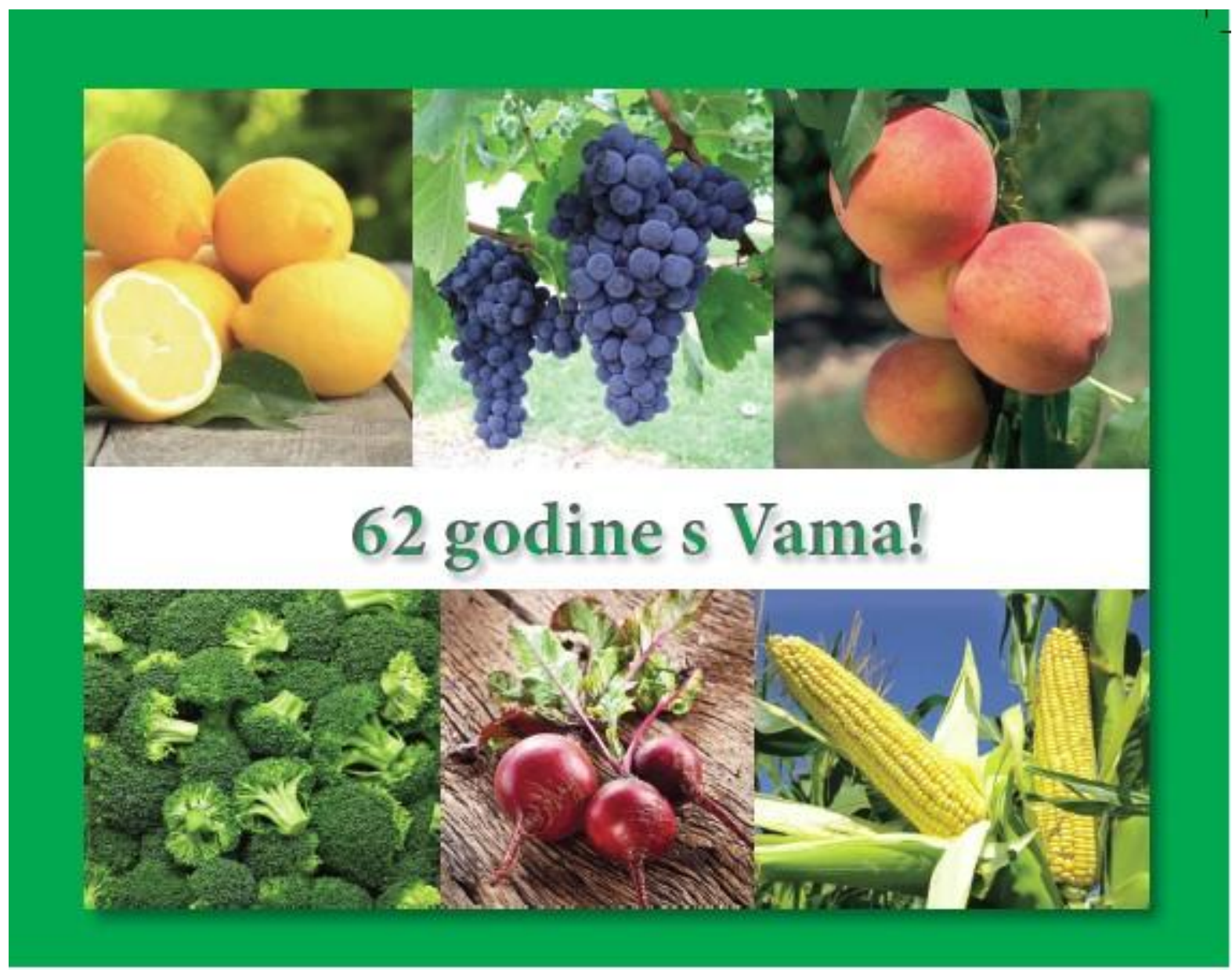

Godina 41 • broj 1-2 • Zagreb 2018.

\title{
UDK 632
}

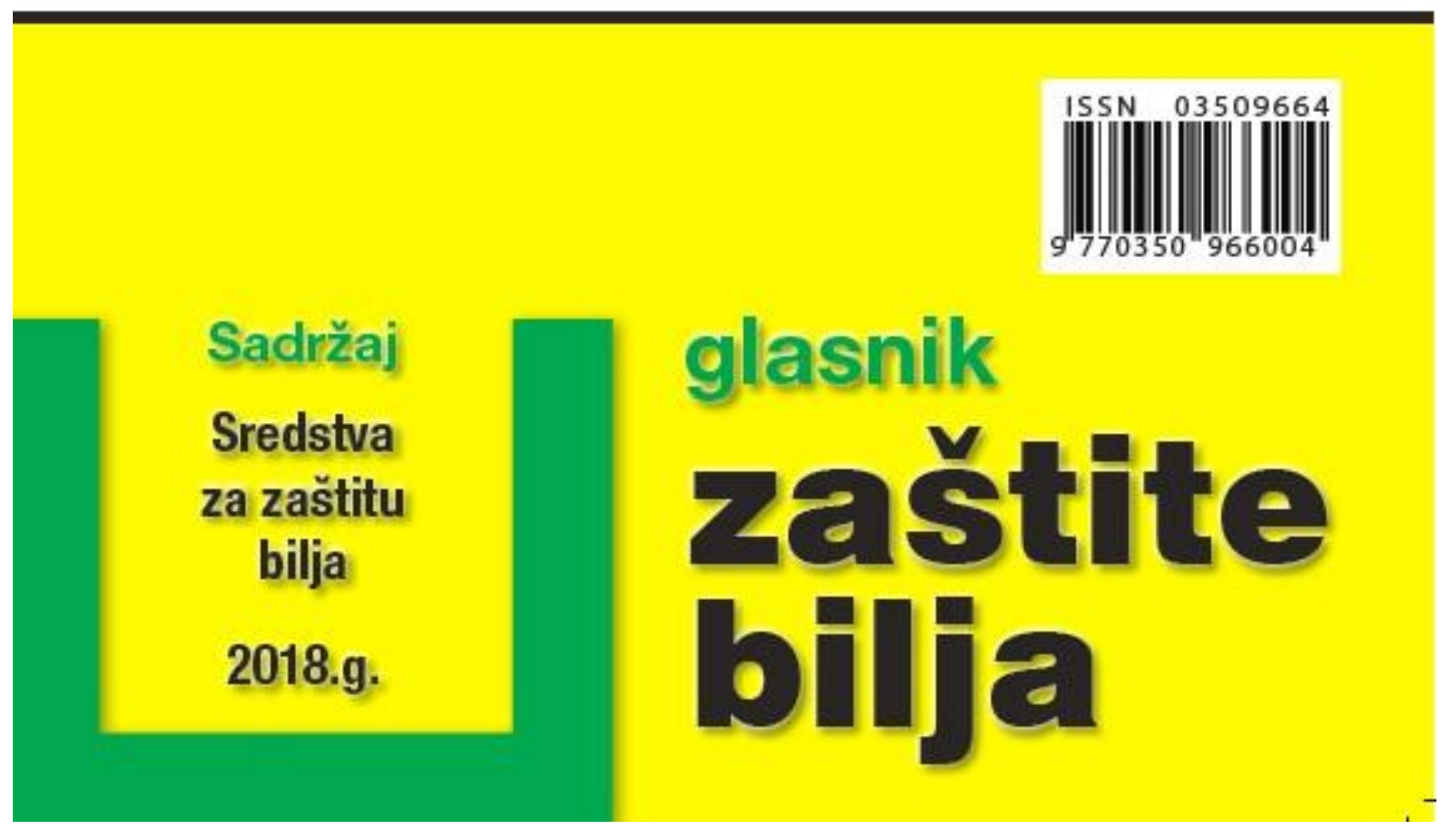





\title{
GLASNIK ZAŠTITE BILJA
}

\author{
Glavni urednik: \\ Katarina Lučić, mag. ekonomije \\ Izvršni urednik: \\ dr. sc. Magdalena Zrakić \\ Stručni urednik: \\ prof. dr. sc. Stjepan Sito
}

Stručno uredništvo:

\author{
prof. dr. sc. Đani Benčić - Zagreb, R. Hrvatska \\ doc. dr. sc. Sanja Fabek Uher - Zagreb, R. Hrvatska \\ dr. sc. David Gluhić, znanstveni suradnik - Poreč, R. Hrvatska \\ prof. dr. sc. Ivo Grgić - Zagreb, R. Hrvatska \\ prof. dr. sc. Ana Jeromel - Zagreb, R. Hrvatska \\ prof. dr. sc. Risto Kukutanov - Štip, Makedonija \\ prof. dr. sc. Tihomir Moslavac - Osijek, R. Hrvatska \\ Mirjana Perica, dipl. ing. agr. - - Split, R. Hrvatska \\ izv.prof.dr.sc. Vlatka Petravić Tominac - Zagreb, R. Hrvatska \\ mag. Tomaž Poje - L Ljubljana, R. Slovenija \\ mag. ing. agr. Valerija Pokos - Varaždin, R. Hrvatska \\ prof. dr. sc. Milan Pospišil - Zagreb, R. Hrvatska \\ dr. sc. Željko Prgomet - Rovinj, R. Hrvatska \\ mr. sc. Nino Rotim - Mostar, BiH \\ prof. dr. Denis Stajnko - Maribor, R. Slovenija \\ Prof. dr. sc. Dragan Škorić, akademik - Novi Sad, R. Srbija \\ prof. dr. Tanas Trajčevski - Skoplje, R. Makedonija \\ prof. dr. Vojislav Trkulja - Banja Luka, BiH \\ izv. prof. dr. sc. Karolina Vrandečić - Osijek, R. Hrvatska \\ dr. sc. Zvonimir Zdunić - Osijek, R. Hrvatska \\ Lektor za hrvatski jezik: \\ Zrinka Sabadoš, prof. \\ Lektor za engleski jezik: \\ Srđan Bohucki, prof. \\ Izdavač:"Zadružna štampa”, d.d. \\ Direktor: \\ Katarina Lučić, mag. ekonomije \\ Dizajn i grefižka priprema: Dario Jelusić • Pro-contra d.o.o., Zagreb \\ Tisak: TISKARA ZELINA d.o.o., Sv. I. Zelina
}

Radovi objavljeni u časopisu , GLASNIK ZAŠTITE BIUA“ referirani su u svjetskim referalnim časopisima:

CAB Abstracts (CAB INTERNATIONAL), FSTA (Food Science and Technology Abstracts),

ZOOR (Zoological Record), Urlichsweb.

GLASNIK ZAŠTITE BILJA, pune 62 godine prati razvoj poljoprivrede kod nas i u svijetu, te pod istim naslovom izlazi 41 godinu. Putem razmjene i citiranja GLASNIK ZAŠTITE BILJA dostupan je čitateljima diljem svijeta. GZB izlazi dvomjesečno - 6 brojeva godišnje.

Pretplata za 2018. godinu iznosi $452,00 \mathrm{kn}$, a za inozemstvo 80 eura

Zagreb, Maksimirska 132, tel./fax: 01/ 2316-060, 2316-050, 2911258

E-mail:zadruzna-stampa@inet.hr ili info@zastitabilja.com.hr www.zastitabilja.com.hr $\cdot$ www.zadruzna.hr 


\section{Sadržaj}

Pregled pripremila:

Andrea Lipovski, mag. ing. agr.

1. HERBICID 16

1.1. Ariloksifenoksi- propionati

1.1.1. Fluazifop-P

1.1.2. Kizalofop-P-etil

1.1.3. Propakizafop

1.1.4. Klodinafop

1.1.5. Fenoksaprop

1.2.1. Cikloksidim

1.2.2. Kletodim

1.3. Fenilpirazolini..

1.3.1. Pinoksaden

1.4. Sulfonilurea herbicidi.

1.4.1. Amidosulfuron

1.4.2. Flazasulfuron

1.4.3. Foramsulfuron

1.4.4. Jodosulfuron

1.4.5. Metasulfuron- metil

1.5. Imidazolinoni

1.5.1. Imazamoks

1.6. Triazolopirimidini.

1.6.1. Florasulam

1.7. Triazoloni

1.7.1. Tienkarbazon-metil

1.8. Triazini.

1.7.1. Terbutilazin

1.9. Triazinoni

1.9.1. Metamitron

1.10. Piridazinoni

1.10.1. Kloridazon

1.11. Fenil- karbamati

1.11.1. Desmedifam

1.12. Uree

1.4.7. Oksasulfuron

1.4.8. Prosulfuron

1.4.9. Rimsulfuron

1.4.10. Tifensulfuron-metil

1.6.2. Piroksulam

1.12.1. Klortoluron

1.11.2. Fenmedifa

1.11.2. Fenmedifam

1.13. Nitrili (benzonitrili)

1.12.2. Linuron

1.4.11. Tribenuron

1.4.12. Triflusulfuron

Tritosulfuron

1.4.14. Mesosulfuron

1.13.1. Bromoksinil

1.14. Benzotiadiazinoni

1.14.1. Bentazon

1.15. Dipiridili.

1.9.2. Metribuzin

1.15.1. Dikvat

1.16. Difenileteri

1.16.1. Oksifluorfen

1.17. $\mathrm{N}$ - fenilftalimidi

1.17.1. Flumioksazin

1.18. Piridinkarboksiamidi.

1.18.1. Diflufenikan

1.19. Triketoni.

1.12.3. Metobromuron 
glasnik zaštite bilja $\underset{\text { godine }}{62}$

1.19.1. Mezotrion $\quad$ 1.19.2. Tembotrion

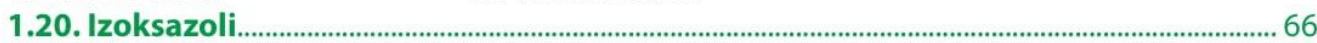

1.20.1. Izoksaflutol

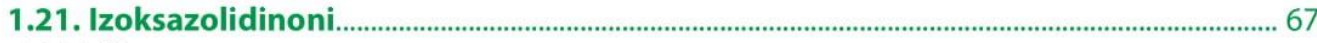

1.21.1. Klomazon

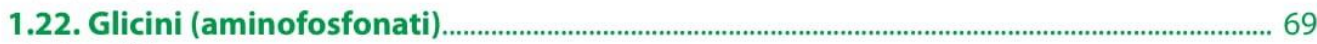

1.22.1. Glifosat

1.23. Fosfinska kiselina (aminofosfonati).................................................................................. 79

1.23.1.Glufosinat

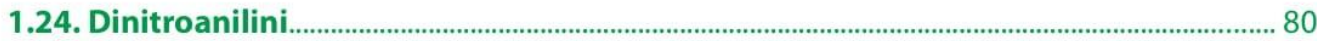

1.24.1. Pendimetalin

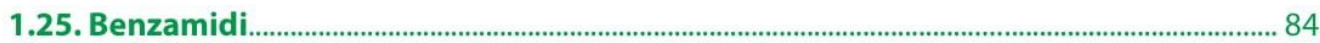

1.25.1. Propizamid

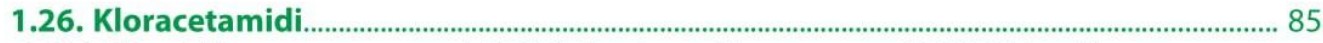

1.26.1. Dimetaklor $\quad$ 1.26.2. S-dimetenamid $\quad$ 1.26.3. Metazaklor

1.26.4. S-metolaklor $\quad$ 1.26.5. Petoksamid

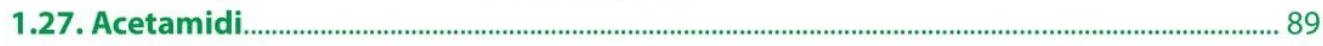

1.27.1. Napropamid

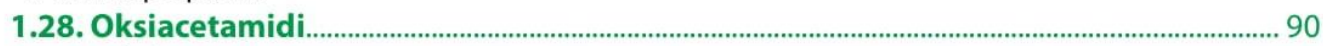

1.28.1. Flufenacet

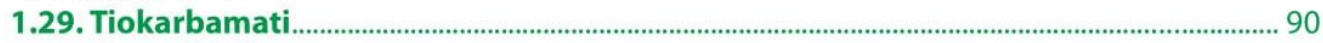

1.29.1. Prosulfokarb

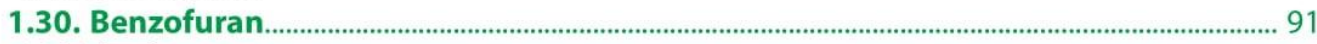

1.30.1. Etofumesat

1.31. Derivati fenoksi-karboksilnih kiselina......................................................................................... 92

1.31.1.2,4- D 1.31.2. Diklorprop-P $=2,4$ DP-P $\quad$ 1.31.3. MCPA 1.31.4. Mekoprop-P

1.32. Derivati benzojeve kiseline ................................................................................................... 95

1.32.1. Dikamba

1.33. Derivati piridin karboksilne kiseline........................................................................................... 97

1.33.1. Fluroksipir 1.33.2. Klopiralid 1.33.3. Pikloram

1.34. Različitog kemijskog podrijetla............................................................................................. 102

1.35.1. Aminopiralid 1.35.2. Flurokloridon

Herbicidni pripravci i kulture u kojima se rabe..............................................................................103

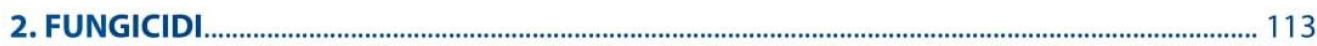

A) ORGANSKI FUNGICIDI

2.1. Acilalanini.

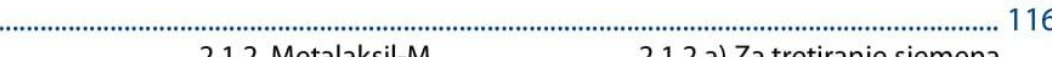

2.1.2.a) Za tretiranje sjemena

2.2. Hidroksi-2-amino-pirimidini..................................................................................................... 121

2.2.1. Bupirimat

2.3. Benzimidazoli..

2.3.1. Tiofanat metil

2.3.2. Tiabendazol

2.4. Toluamidi..

2.4.1. Zoksamid

2.5. Fenilurea..

2.6. Piridinilmetil- benzamidi.

2.6.1. Fluopikolid 
2.7. Piridinil etil benzamid

2.7.1. Fluopiram

2.8. Oksatin karboksamidi.

2.8.1. Karboksin

126

2.9. Piridin karboksamidi.

2.8.1.a) Za tretiranje sjemena

2.9.1. Boskalid

2.10. Metoksi-akrilati ("Strobilurini")

2.10.1. Azoksistrobin

2.11. Pirazol-karboksamidi

2.11.1. Fluksapiroksad

$$
\begin{array}{ll}
\text { 2.11.2. Izopirazam } & \text { 2.11.3. Benzovindiflupir } \\
\text { 2.11.4. Biksafen } & \text { 2.11.5. Sedaksan }
\end{array}
$$

2.12. Metoksi-karbamati ("Strobilurini")

2.12.1. Piraklostrobin

2.13. Oksimino acetati ("Strobilurini"). 138

2.13.1. Krezoksim-metil 2.13.2. Trifloksistrobin

2.14. Oksimino-acetamidi ("Strobilurini")

2.14.1. Dimoksistrobin

2.15. Oksazolidindioni

2.15.1. Famoksadon

2.16. Imidazolinoni. 143

2.16.1. Fenamidon

2.17. Cianoimidazoli.

2.17.1. Ciazofamid

2.18. Sulfamoil-triazoli. 144

2.18.1. Amisulbrom

2.19. Dinitrofenil krotonati. 144

2.19.1. Meptil dinokap

2.20. 2,6-dinitroanilini. 145

2.20.1. Fluazinam

2.21. Triazolo-pirimidilamini.

2.21.1. Ametoktradin

2.22. Anilino-pirimidini. 146

2.22.1. Ciprodinil 2.22.2. Pirimetanil

2.23. Kinolini.

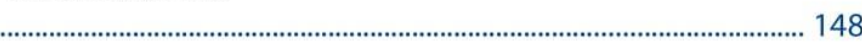

2.23.1. Kinoksifen 2.23.2. 8-hidroksikinolin

2.24. Fenilpiroli 2.24.1. Fludioksonil 2.24.1.a) Za tretiranje sjemena 150

2.25. Dikarboksimidi 2.25.1. Iprodion

2.26. Karbamati. 151

2.26.1. Propamokarb-hidroklorid

2.27. Amidi karboksilne kiseline. 2.27.1. Dimetomorf

2.27.2. Iprovalikarb 2.27.4. Bentiavalikarb

2.28. Imidazoli

ola (grupa I)

2.28.1. Imazalil

2.28.2. Prokloraz 
glasnik zaštite bilja $\underset{\text { godine }}{62}$

2.29. Triazoli

Inhibitori biosinteze ergosterola (grupa I)

$\begin{array}{lll}\text { 2.29.1. Ciprokonazol } & 2.29 .6 \text {. Metkonazol } & 2.29 .11 \text {. Tebukonazol } \\ \text { 2.29.2. Difenkonazol } & 2.29 .7 \text {. Miklobutanil } & 2.29 .11 \text {. a) Za tretiranje sjemena } \\ \text { 2.29.2. a) Za tretiranje sjemena } & 2.29 .8 \text {. Penkonazol } & 2.29 .12 \text {. Tetrakonazol } \\ \text { 2.29.3. Epoksikonazol } & 2.29 .9 \text {. Propikonazol } & 2.29 .13 \text {. Triadimenol } \\ \text { 2.29.4. Fenbukonazol } & 2.29 .10 \text {. Protiokonazol } & \\ \text { 2.29.5. Flutriafol } & 2.29 .10 \text {. a) Za tretiranje sjemena } & \end{array}$

2.30. Morfolini.

Inhibitori biosinteze ergosterola (grupa II)

2.30.1. Fenpropimorf

2.31. Piperidini.

Inhibitori biosinteze ergosterola (grupa II)

2.31.1. Fenpropidin

2.32. Spiroketalamini

Inhibitori biosinteze ergosterola (grupa II)

2.32.1. Spiroksamin

2.33. Hidroksianilidi

Inhibitori biosinteze ergosterola (grupa III)

2.33.1. Fenheksamid

2.34. Ditiokarbamati.

2.34.1. Ciram

2.34.2. Mankozeb

2.34.3. Metiram

2.34.4. Propineb

2.34.5. Tiram

2.35. Ftalimidi

2.35.2. Kaptan

2.34.5. a) Za tretiranje sjemena

2.35.1. Folpet

2.35.2. a) Za tretiranje sjemena

2.36. Kloronitrili.

2.36.1. Klortalonil

2.37. Guanidini

2.37.1. Dodin

2.38. Kinoni.

2.38.1. Ditianon

2.39. Cianoacetamid-oksimi

2.39.1. Cimoksanil

2.40. Etil fosfonati.

2.40.1. Fosetil- aluminij

2.41. Kinazolinoni.

2.41.1. Prokinazid

2.42. Benzofenoni.

2.42.1. Metrafenon

2.43. Benzoilpiridini.

2.43.1. Piriofenon

2.44. Fenil-acetamidi.

2.44.1. Ciflufenamid

\section{B) ANORGANSKI FUNGICIDI}

2.45. Fungicidi na osnovi bakra (Cu)

2.45.1. Bakarni (I) oksid

2.45.4. Bakar hidroksid - kalcij sulfat kompleks
2.45.2. Bakarni oksiklorid

2.45.5. Kombinacije bakra i organskih fungicida
2.45.3. Bakarni hidroksid

2.45.6. Kombinacije bakra i mineralnih ulja 
2.46. Fungicidi na osnovi sumpora (S) ............................................................................................ 200

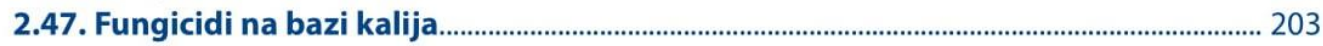

2.47.1. Kalijevi fosfonati 2.47.2. Kalijev hidrogen karbonat

2.48. Mikrobiološki fungicidi/inokulanti......................................................................................... 204

2.48.1. Pseudomonas sp. $\quad$ 2.48.2. Pepino mosaic virus

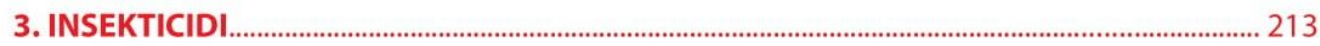

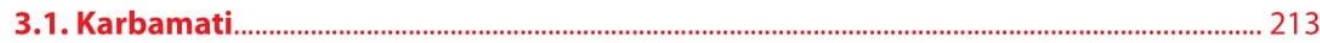

3.1.1. Metiokarb 3.1.2. Pirimikarb 3.1.1. a) Za tretiranje tla i/ili sjemena

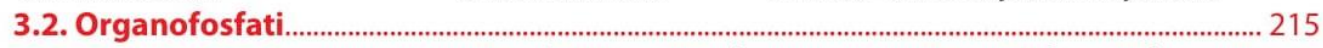

$\begin{array}{lll}\text { 3.2.1. Dimetoat } & \text { 3.2.2. a) Za tretiranje tla } & \text { 3.2.3. Pirimifos-metil } \\ \text { 3.2.2. Klorpirifos } & \text { 3.2.4. Fosmet } & 3.2 .3 \text {. a) Za dezinsekciju žitarica }\end{array}$

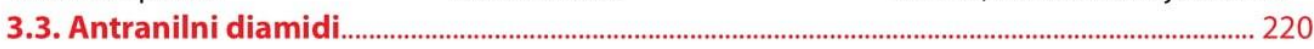

3.3.1 Klorantraniliprol

3.4. Sintetski piretroidi.......................................................................................................................... 221

3.4.1. Alfa-cipermetrin 3.4.3. a) Za dezinsekciju 3.4.6. Tau-fluvalinat

3.4.2. Cipermetrin 3.4.4. Esfenvalerat 3.4.7. Teflutrin

3.4.3. Deltametrin 3.4.5. Gama i lambda cihalotrin 3.4.7. a) Za tretiranje tla i/ili sjemena

3.5. Neonikotinoidi.

............................................. 239

3.5.1. Acetamiprid

3.5.2. Imidakloprid

3.5.2.a) Za tretiranje sjemena, gomolja i lučica

3.6. Avermektini.

$$
\begin{aligned}
& \text { 3.5.3. Klotianidin } \\
& \text { 3.5.4. Tiakloprid } \\
& \text { 3.5.4.a) Za tretiranje sjemena, } \\
& \text { gomolja i lučica }
\end{aligned}
$$

3.5.5. Tiametoksam

3.5.4. Tiakloprid 3.5.5. a) Za tretiranje sjemena

3.6.1 Abamektin 3.6.2. Emamektin benzoat

3.7. Milbemicini.

3.7.1. Milbemektin

3.8. Spinosini.

3.8.1. Spinosad

3.9. Pimetrozin (Piridini)

3.9.1. Pimetrozin

3.10. Derivati benzoiluree - (Regulatori razvoja insekata) .

3.10.1. Diflubenzuron 3.10.2. Lufenuron

3.8.1. Spinetoram

3.11. Diacilhidrazini.

3.11.2. Tebufenozid

3.12. Keto-enoli.

3.12.1. Spirodiklofen

.....................................

3.13. Insekticidi različitog kemijskog podrijetla

3.13.1. Fenoksikarb 3.13.3. Fostiazat

3.13.2. Flonikamid

3.13.4. Indoksakarb

3.14. Mineralna ulja.

3.14.1. Parafinska ulja

3.15. Pripravci za fumigaciju..

3.15.1. Aluminijev fosfid

3.14.2. Kombinirani pripravci bakra i mineralnog ulja

3.13.5. Metaflumizon

3.16. Mikrobiološki insekticidi

3.16.1. Bacillus thuringiensis

3.17. Dijatomejska zemlja.

3.15.2. Magnezijev fosfid

3.10.3. Teflubenzuron

3.15.2. Cydia pomonella granulovirus 
glasnik zaštite bilja $\underset{\text { godine }}{62}$

4. AKARICIDI

4.1. Abamektin

4.2. Heksitiazoks

4.4. Fenazakin

4.7. Tebufenpirad

4.5. Klofentezin

4.8. Piriproksifen

4.3. Etoksazol

4.6. Spirodiklofen

4.9. Ciflumetofen

5. NEMATOCIDI.

5.1. Dazomet

5.2. Fostiazat

5.3. Oksamil

5.4. Fluopiram

6. LIMACIDI

6.1. Metaldehid

6.2. Željezo (III) pirofosfat

7. KORVIFUGI

7.1. Metiokarb

7.2. Ciram

8. REGULATORI RASTA | FIZIOTROP|

8.1. Etefon

8.2. Klormekvat

8.3. Klorprofam

8.4. Maleinski hidrazid

9. OSTALA SREDSTVA

9.1. Benzojeva kiselina

10. OKVAŠIVAČ
8.5. Proheksadion

8.6. Trineksapak

8.7. Indolilbutanska kiselina

8.8. 1-dekanol
11. ATRAKTANTI

Indeks pripravaka

Indeks djelatnih tvari

Tablica razrjeđivanja
8.9. 1-metilciklopropen

8.10. Giberelini

8.11 Etilen

8.12. Natrijevi nitrofenolati

\subsection{Vapno}

98 


\section{Sredstva za zaštitu bilja 2018.}

\section{Sažetak}

Sredstva za zaštitu bilja 2018. sadrži pregled sredstava za zaštitu bilja dozvoljenih za uporabu u Republici Hrvatskoj u 2018. godini. Sva sredstva koja se stavljaju u promet u Republici Hrvatskoj moraju biti registrirana pri nadležnoj upravi Ministarstva poljoprivrede. Informacije o sredstvima za zaštitu bilja mogu se pronaći i na web stranicama Ministarstva poljoprivrede (FIS Web Portal).

Sredstva su podijeljena prema namjeni u najznačajnije skupine: herbicidi, fungicidi i zoocidi. Svaka skupina sadrži pregled sredstava prema aktivnim tvarima. O svakom sredstvu navedeni su slijedeći podaci: trgovački naziv, formulacija, količina djelatne tvari, proizvođač i distributer, te koncentracija ili doza za suzbijanje uz popis štetočina i kultura za koje sredstvo ima dozvolu za primjenu. Također, navedene su i karence za kulture u kojima je primjena dozvoljena.

Zbog brojnih izmjena te dopuna rješenja i registracija, sredstva za zaštitu bilja se smiju koristiti isključivo prema uputama za uporabu koje se nalaze na ambalaži proizvoda. Svaka primjena sredstava za zaštitu bilja na bilo koji drugi način od navedenog u uputi za korištenje i na etiketi obavlja se isključivo na vlastitu odgovornost.

Ključne riječi: sredstva za zaštitu bilja, herbicidi, fungicidi, zoocidi.

Review

\section{Plant Protection Products 2018.}

\section{Summary}

The document Plant Protection Products 2018 gives an overview of plant protection products permitted for use in the Republic of Croatia in 2018. All plant protection products that are put in distribution in the Republic of Croatia must be registered with the competent authority of the Ministry of Agriculture. Information on registered plant protection products can be found on the website of the Ministry of Agriculture (the FIS Web Portal).

Plant protection products are, according to their application, divided into three major groups: herbicides, fungicides and zoocides. Each group offers an overview of products according to active substances. Each plant protection product, along with a list of pests and crops for which a permit for application was obtained, includes the following information: trade name, formulation, amount of active ingredients, manufacturer and distributor, and suppression concentration or dosage. Also listed are due pre-harvest intervals of crops for which the application is allowed.

Due to the numerous amendments to relevant decisions and registration procedures, plant protection products may only be used according to the instructions for use indicated on the packaging. Any application of plant protection products in any manner other than specified in the instructions for use and on the label shall be considered performed exclusively at one's own risk.

Key words: plant protection products, herbicides, fungicides, zoocides. 


\section{HERBICIDI}

\subsection{Ariloksifenoksi-propionati}

(engl. Aryloxyphenoxy-propionate 'FOPs')

Herbicidi iz skupine ariloksifenoksi-propionata (derivata fenoksipropionata) inhibiraju enzim acetilkoenzim A karboksilazu (ACCase) koji je odgovoran za sintezu malonil koenzima A i masnih kiselina zbog čega dolazi do spriječavanja tvorbe lipida koji su biljci neophodni za izgradnju staničnih membrana. Na osnovu navedenog mehanizma djelovanja ovi herbicidi su razvrstani u HRAC grupu A. Predstavljaju važnu skupinu visoko selektivnih herbicida za suzbijanje jednogodišnjih i višegodišnjih travnih korova u širokolisnim kulturama (“graminicidi"). Pretpostavlja se da je tolerantnost širokolisnih biljaka na ovu grupu herbicida rezultat neznatnih razlika u samoj strukturi navedenog enzima.

Herbicidi iz ove skupine se primjenjuju nakon nicanja biljke i korova. Rabe se u relativno niskim količinama po jedinici površine. Visoko su selektivni i vrlo male toksičnosti. Svojom pojavom znatno su unaprijedili kemijsku borbu protiv travnih korova u dikotilednim kulturama.

\subsubsection{Fluazifop - $\mathbf{P}$}

Djelatna tvar izaziva inhibiciju enzima ACCase, odgovornog za sinteze lipida neophodnih u izgradnji staničnih membrana, i to isključivo kod trava. Stanične membrane određuju što može ući ili izaći iz stanice. Ne suzbija: Festuca ovina, Festuca rubra i Poa annua.

Ne primjenjuje se u kombinaciji s drugim herbicidima.

Potpuno selektivan na širokolisne usjeve. I u dvostruko višim dozama od preporučenih, nanesen na listove uzgojenih biljaka ne izaziva oštećenja. Apsorbira se preko lista, prodire ksilemom i floemom u točke rasta. Prvi simptomi su vidljivi nakon 7-14 dana od prskanja, a do konačnog sušenja dolazi nakon 3-4 tjedna. Sušenje se postupno prenosi s najmlađih k starijim dijelovima biljke. Suzbija jednogodišnje i višegodišnje travne korove u dikotiledonim kulturama. Jednogodišnje trave trebaju u vrijeme tretiranja biti s 2-4 lista, a višegodišnje od 15-20 cm.

$\mathrm{LD}_{50}$ 2925. S.O. = III.

\subsubsection{Kizalofop-P-etil (kizalofop-P-tefuril)}

Djelatna tvar izaziva inhibiciju enzima ACCase odgovornog za sinteze lipida neophodnih u izgradnji staničnih membrana i to isključivo kod trava. Stanične membrane određuju što može ući ili izaći iz stanice.

Primjenjuje se kao graminicid u usjevima/nasadima: šećerne i stočne repe, soje (samo prije cvatnje), suncokreta, uljane repice, krumpira, vinove loze i jabuka; u fazi 3-6 listova travnih korova. Za bolje djelovanje može se dodati okvašivač. Osjetljive kulture na zanošenje: žitarice i kukuruz. Ne koristiti u mladom krumpiru i povrću.

LD $_{50}$ 1480. S.O. = III. K - 77 dana krumpir, šećerna repa, soja, suncokret; 49 dana vinova loza. 


\subsubsection{Propakizafop}

Djelatna tvar izaziva inhibiciju enzima ACCase odgovornog za sinteze lipida neophodnih u izgradnji staničnih membrana i to isključivo kod trava. Stanične membrane određuju što može ući ili izaći iz stanice.

Biljka ga apsorbira putem lista. Brzo se translocira u sve dijelove biljke. Za manje od 1 sata $u$ cjelosti je u biljci i nema mogućnosti ispiranja padalinama i smanjenja herbicidnog djelovanja.

$\mathrm{LD}_{50}$ 5000. S.O. = III.

\subsubsection{Klodinafop}

Djelatna tvar koja se koristi u pripravcima za suzbijanje jednogodišnjih travnih korova. Sistemičnog je djelovanja. Primjenjuje se u vrijeme aktivnog porasta korova, kod ljuljeva ne kasnije od stadija busanja korova.

$\mathrm{LD}_{50}$ - S.O. = III. K - OVP.

\subsubsection{Fenoksaprop}

Djelatna tvar izaziva inhibiciju enzima ACCase odgovornog za sinteze lipida neophodnih u izgradnji staničnih membrana i to isključivo kod trava. Stanične membrane određuju što može ući ili izaći iz stanice. Pripravak je namijenjen za suzbijanje jednogodišnjih trava u usjevima: pšenice i ječma: Phalaris paradoxa, Poa trivialis, Avena fatua, Apera spica-venti... Ne suzbija: Agropyron repens, Bromus spp., Cynodon dactylon, Festuca spp., Lolium multiflorum, Lolium perenne, Poa annua i Poa pratensis. Biljka usvaja preparat već 1-3 sata nakon prskanja, tako da ga kiša ne može isprati.

LD $_{50}$ 2260. S.O. = III. K - OVP.

\subsection{Cikloheksandioni}

\section{(engl. Cyclohexanedione 'DIMs')}

Cikloheksandioni imaju isti mehanizam djelovanja kao i ariloksifenoksi-propionati, odnosno i oni inhibiraju enzim acetilkoenzim A karboksilazu (ACCase) koji je odgovoran za sintezu malonil koenzima A i masnih kiselina zbog čega dolazi do inhibicije biokemijskih procesa sinteze lipida kod trava, na temelju čega su i oni razvrstani u HRAC grupu A. Biljka ih apsorbira preko lista i translocira do meristema.

Cikloheksandioni su relativno mala, ali vrlo značajna skupina translokacijski visokoselektivnih herbicida koji su kao i derivati fenoksipropionata namijenjeni suzbijanju travnih vrsta korova u širokolisnim kulturama ("graminicidi"). U tlu se relativno brzo razgrade. Skloni su ispiranju. Vrlo su niske toksičnosti. Selekcijom kulture stanica u SAD-u i nekim europskim zemljama su uzgojeni hibridi kukuruza rezistentni prema predstavnicima ove skupine herbicida. Svojom pojavom znatno su unaprijedili borbu protiv travnih korova u dikotiledonim kulturama. 


\subsubsection{Cikloksidim}

Djelatna tvar izaziva inhibiciju enzima ACCase odgovornog za sinteze lipida neophodnih u izgradnji staničnih membrana i to isključivo kod trava. Stanične membrane određuju što može ući ili izaći iz stanice. Ne suzbija Poa annua. U krumpiru se ne koristi u kombinaciji s drugim pripravcima. Pripravak za suzbijanje jednogodišnjih i višegodišnjih travnih korova u svim širokolisnim usjevima. Djelatna tvar translocira kroz cijelu biljku i zaustavlja rast meristemskog tkiva. Za tri tjedna korovne biljke potpuno propadaju. Povoljni uvjeti za rast biljke tj. toplo i vlažno vrijeme ubrzavaju herbicidni učinak. Jednogodišnje trave trebaju imati od 2 do 5 listova (do konca busanja), a višegodišnje trave trebaju u vrijeme prskanja biti 10-15 cm visine s izuzetkom sirka iz rizoma koji treba biti od 20-40 cm. Već dva sata nakon primjene u cijelosti je u biljci i nema opasnosti od ispiranja i smanjenog djelovanja.

\section{$\mathrm{LD}_{50}$ 3940. S.O. = III.}

\subsubsection{Kletodim}

Djelatna tvar izaziva inhibiciju enzima ACCase odgovornog za sinteze lipida neophodnih u izgradnji staničnih membrana i to isključivo kod trava. Stanične membrane određuju što može ući ili izaći iz stanice.

Vrlo se brzo apsorbira putem lista i translocira cijelom biljkom te ubrzano nakuplja u meristemskim tkivima. Već jedan sat nakon primjene sav je u biljci i nema opasnosti od ispiranja kišom. Zbog svoje niske toksičnosti i brze razgradnje u tlu minimalni su rizici od mogućnosti trovanja ljudi koji ga primjenjuju te riba, kao i podzemnih voda. Pripada inhibitorima rasta meristema i biosinteze lipida. U osjetljivim biljkama kletodim se veže na enzim acetil koenzim A karboksilazu odgovoran za sintezu lipida. Prvi simptomi koji se na osjetljivim biljkama mogu uočiti jesu: zaustavljanje rasta (sedam dana nakon primjene), tkiva u blizini meristema postaju smeđa i trunu, novo formirani listovi postaju žuti (klorotični) i postupno odumiru. Kako stariji listovi odumiru, pokazuju promjenu u boji od narančaste, crvene do ljubičaste. Kletodim učinkovito suzbija podzemne i nadzemne dijelove trava čime spriječava njihov novi rast. Kod nas se primjenjuje u usjevima šećerne repe, soje, suncokreta, uljane repice, luka, češnjaka i krumpira. U usjevu šećerne repe se preporučuje split aplikacija. Najučinkovitiji je u vrijeme aktivnog rasta korova kada su u mlađem razvojnom stadiju ( jednog. trave 3-5 listova, višegodišnje trave $-25 \mathrm{~cm}$, pirika $-25 \mathrm{~cm}$ i trska oko $50 \mathrm{~cm}$ ili $4-5$ listova).

S.O. = III. K - 35 dana rajčica, 42 dana grah (ne za vrlo rane sorte), 49 dana šećerna repa i krumpir, OVP ostalo.

\subsection{Fenilpirazolini}

(engl. Phenylpyrazoline'DEN')

Fenilpirazolini imaju isti mehanizam djelovanja kao i ariloksifenoksi - propionati i cikloheksandioni, odnosno i oni inhibiraju enzim acetilkoenzim A karboksilazu (ACCase) koji je odgovoran za sintezu malonil koenzima A i masnih kiselina zbog čega dolazi do inhibicije biokemijskih procesa sinteze lipida kod trava, na temelju čega su i oni razvrstani u 


\section{HRAC grupu A.}

Njihov, za sada, jedini predstavnik pinoksaden je namijenjen za suzbijanje travnih vrsta korova u usjevu strnih žita. Prema svojoj strukturi ovaj herbicid nije sličan postojećim "fop" ili "dim" herbicidima za suzbijanje travnih korova. Nema ograničenja u plodosmjeni.

\subsubsection{Pinoksaden}

Djelatna tvar izaziva inhibiciju enzima ACCase, odgovornog za sinteze lipida neophodnih u izgradnji staničnih membrana i to isključivo kod trava. Stanične membrane određuju što može ući ili izaći iz stanice. Rabi se uz pomoćno sredstvo specijalno razvijeno za ovaj pripravak.

Kompatibilan i široke mogućnosti glede izbora vremena primjene. Nema ograničenja u plodosmjeni.

$\mathrm{LD}_{50}$ - 5000, S.O.=III, K - OVP.

\subsection{Sulfonilurea herbicidi}

(engl. Sulfonylurea)

Herbicidi iz grupe sulfonilurea kod osjetljivih biljaka inhibiraju rad enzima acetolaktat sintetaze (ALS) zbog čega u biljci izostaje biosinteza esencijalnih aminokiselina: valina, leucina i izoleucina, na temelju čega su razvrstani u HRAC grupu B. Izostanak biosinteze navedenih aminokiselina rezultira brzim prestankom rasta, a potom i ugibanjem tretiranih biljaka. Ove herbicide biljke prvenstveno usvajaju preko lista, zbog čega ih isključivo primjenjujemo nakon nicanja korova. Sulfoniluree karakterizira i visoka biološka učinkovitost na veliki broj važnih jednogodišnjih uskolisnih i širokolisnih korova, kratko vrijeme poluraspada (degradacija se odvija brže u tlima s nižom pH vrijednosti), mala toksičnost za životinje i ljude (čovjek i životinje ne posjeduju ALS enzim i ne mogu sintetizirati ove aminokiseline). Za sve predstavnike sulfonilurea grupe karakteristično je da su vrlo djelotvorni u niskim dozama. Skloni su ispiranju, no kako se rabe u niskim dozama, ekološki su prihvatljiviji od klasičnih herbicida.

Herbicidi iz grupe sulfonilurea su relativno nova skupina herbicida koja je sve više zastupljena u gotovo svim značajnijim kulturama. Međutim, sve veći problem ove perspektivne grupe herbicida je sve masovnija pojava rezistentnosti na pojedine pripravke. Također, treba izbjegavati aplikaciju herbicida iz grupe sulfonilurea u slučajevima kada se na tlu nalaze površinske vode ili ako je tlo zasićeno vodom, a zbog moguće fitotoksičnosti potrebno je posebno voditi brigu o ispiranju prskalice i opreme. Pri primjeni se treba točno pridržavati uputa proizvođača te poštivati ograničenja i plodored jer su pojedini (stariji spojevi) vrlo perzistentni pa ograničavaju plodored.

\subsubsection{Amidosulfuron}

Pripravci na bazi amidosulfurona su selektivni sistemični herbicidi namijenjeni za suzbijanje jednogodišnjih i manjeg broja višegodišnjih širokolisnih korova u usjevima ozime i jare pšenice i ječma (ljepljiva broćika - Galium aparine, ptičji dvornik - Polygonum aviculare, slakasti dvornik - Polygonum convulvulus, veliki dvornik - Polygonum persicaria, kamilica - Matricaria chamomilla, ambrozija - Ambrosia elatior i dr.). Korovna biljka ga apsorbira putem lista, a 
neznatnim dijelom i preko tla. Učinak na korove vidljiv je nakon 3 do 5 tjedana od primjene. Primjena: od tri lista do pojave drugog koljenca pšenice i ječma. Za suzbijanje, Galium spp. može se primijeniti i u busanju. Rabi se i za suzbijanje korova na travnjacima, pašnjacima i golf igralištima. Nakon prskanja, dovoljan je jedan sat bez padalina da se u potpunosti usvoji. Nakon usvajanja zaustavlja se rast korova, a nakon 7 - 14 dana pojavljuju se crvenkasto-plavo-ljubičaste mrlje kao prvi znak letalnih promjena u biljci. Vrlo dobro ga podnose sve vrste žitarica: ozima i jara pšenica, ozimi i jari ječam, ozima raž i pšenoraž.

Može se rabiti u usjevu zobi i pri niskim temperaturama $\left(\mathrm{od}+5^{\circ} \mathrm{C}\right)$.

$\mathrm{LD}_{50}$ 5000. T - 0,05. S.O. = III. K - OVP, na travnjacima i pašnjacima: 21 dan.

\subsubsection{Flazasulfuron}

Pripravak na bazi flazasulfurona je kontaktno-sistemično-rezidualni herbicid namijenjen za suzbijanje većine jednogodišnjih i nekih višegodišnjih korova u vinogradima i oko željezničkih pruga. Dobro se nadopunjava s pripravcima na osnovi glifosata i sulfosata.

Primjenjuje se u nasadima vinove loze starijim od 4 god. Treba spriječiti dodir s lisnom masom i izbojcima loze. Primjenjuje se u pre-em. (sam) i post-em. (sam ili u kombinaciji s gore navedenim herbicidima). Najbolje učinke postiže u vrijeme intezivnog rasta korova.

$\mathrm{LD}_{50} 4700$. O - III. T - 0,01 grožđe. $\mathrm{K}$ - 63 dana vinova loza.

\subsubsection{Foramsulfuron}

Pripravci na bazi foramsulfurona su noviji sistemični selektivni post-em. Herbicidi iz grupe sulfonilurea namijenjeni za suzbijanje jednogodišnjih uskolisnih (koštan, muharike, svračica) i širokolisnih korova (europski mračnjak, šćir, pelinolisna ambrozija, lobode), te za smanjenje zakorovljenosti s višegodišnjim uskolisnim korovima (sirak, pirika) u usjevu merkantilnog kukuruza. Korovna biljka usvaja foramsulfuron preko lista, a neznatno i preko tla. Izoksadifen etil koji se kao herbicidni zaštitnik nalazi u pripravku ubrzava razgradnju foramsulfurona u kukuruzu, a usporava u korovnim biljkama. Ravnomjerno se raspoređuje unutar biljke i izaziva inhibiciju biosinteze lančanih aminokiselina. Kukuruz treba biti u fazi od 2-6 lista, a korovi od 1 do najviše 5 kod uskolisnih i 2 do 4 lista kada se radi o širokolisnim. Može se kombinirati s djelatnim tvarima kao što su: dikamba, bromoksinil, piridat, 2,4-D, terbutilazin i dimetenamid u ranom postu. Dva sata nakon prskanja u cijelosti je usvojen i padaline nakon tog vremena nemaju utjecaja na njegovu učinkovitost.

$\mathrm{LD}_{50}>$ 5000. S.O. = III. T - 0,05.

\subsubsection{Jodosulfuron}

Pripravci na bazi jodosulfurona su sistemični selektivni herbicidi namijenjeni za suzbijanje jednogodišnjih širokolisnih i nekih uskolisnih korova u usjevu pšenice i ječma. Kao i druge djelatne tvari iz ove skupine, u korovnim biljkama izaziva inhibiciju sinteze aminokiselina. Unutar biljke širi se floemom i ksilemom, a herbicidni učinak vidljiv je nakon 4-6 tjedana od tretiranja. Dva sata nakon prskanja pripravci su u cijelosti u biljci i naknadne oborine nemaju utjecaja na učinkovitost. 
Kontaktno-sistemični herbicid za suzbijanje: uskolisnih korova (Apera spica venti, Lolium spp. Phalaris spp., Poa annua, Poa trivialis) i širokolisnih korova (Amaranthus retroflexus, Anagalis arvensis, Anthemis spp., Atriplex spp., Bifora radians, Capsella bursa pastoris, Centaurea cyanus, Chenopodium album, Cirsium arvense, Galeopsisi spp., Galinsoga ciliata, Galium aparine, Lamium spp., Matricaria spp., Myosotis arvensis, Papaver rhoeas, Polygonum spp., Ranunculus arvensis, Raphanus raphanistrum, Rumex spp., Senecio vulgaris, Sinapis arvensis, Sonchus spp., Stellaria media, Trifolium spp., Vicia spp., Viola spp., kao i samonikle uljane repice).

$\mathrm{LD}_{50}$ 2678. S.O. = III. K - OVP.

\subsubsection{Metsulfuron-metil}

Pripravci na bazi metsufuron-metila su sistemični selektivni herbicidi namjenjeni za suzbijanje jednogodišnjih i višegodišnjih širokolisnih korova u usjevima ozime pšenice i jarog ječma. Biljka ovu djelatnu tvar usvaja korijenom i listom, poslije čega se ona sistemično translocira bazipetalno i akropetalno. Za poboljšanje djelovanja na Gallium spp. preporučuje se dodatak najniže doze fluroksipir estera.

$\mathrm{LD}_{50}$ 5000. T - 0,05. O - ISO, K - OVP.

\subsubsection{Nikosulfuron}

Pripravci na bazi nikosulfurona su sistemični selektivni folijarni herbicidi namijenjeni za suzbijanje jednogodišnjih i višegodišnjih travnih (sirak iz rizoma, pirika i drugi), kao i nekih širokolisnih korova u usjevu kukuruza. Biljka ovu djelatnu tvar usvaja preko lista, zbog čega kukuruz u vrijeme tretiranja treba imati od 3-6 listova. Ozime žitarice sijati najmanje 4, a jare 8 mjeseci nakon primjene. 10 mjeseci nakon primjene siju se soja i grah, a sve ostale kulture nakon 12 mjeseci.

LD ${ }_{50}$ 6000. S.O. - III. K - 63 dana.

\subsubsection{Oksasulfuron}

Pripravci na bazi oksasulfurona su sistemični selektivni translokacijski herbicidi namijenjeni za suzbijanje brojnih jednogodišnjih širokolisnih i nekih uskolisnih korova u usjevu soje. Biljka ovu djelatnu tvar usvaja putem lista, a u vlažnom tlu i putem korijena. Kod neujednačenog rasta korova može se primijeniti i u dvije polovične doze $(2 \times 50 \mathrm{~g} / \mathrm{ha}) \mathrm{u}$ razmaku od jednog do dva tjedna. Prskati treba kada je soja od prva tri lista do četiri trolista, a korovi od 2-6 lista. Do ugibanja korova dolazi približno tri tjedna nakon primjene.

$\mathrm{LD}_{50}>$ 5000. S.O. - III. K - OVP.

\subsubsection{Prosulfuron}

Pripravci na bazi prosulfurona su sistemični folijarni herbicidi namijenjeni za suzbijanje najvažnijih jednogodišnjih širokolisnih korova (hrapavog šćira, pelinolisne ambrozije, bijele lobode, običnog malog čička, europskog mračnjaka, velikog dvornika, slatkastog dvornika, poljske gorušice, i dr.) u usjevu kukuruza bez podusjeva.

$\mathrm{LD}_{50} 546, \mathrm{~T}-0,05 \mathrm{mg} / \mathrm{kg}$. S.O. III. 


\subsubsection{Rimsulfuron}

Pripravci na bazi rimsulfurona su sistemični folijarni herbicidi namijenjeni za suzbijanje jednogodišnjih i višegodišnjih travnih, kao i jednogodišnjih i nekih višegodišnjih širokolisnih korova u usjevu kukuruza i krumpira. Djelatna tvar se translocira u cijelu biljku i koncentrira u točkama rasta. Kukuruz u vrijeme prskanja mora imati od 2-7 listova. Može se kombinirati s pripravcima na bazi: bentazona, dikambe, metribuzina, tifensulfurona i dr. (za širokolisne korove koje rimsulfuron slabije suzbija). Učinkovit na jednogodišnje (koštan, svračica, muharike, proso) i višegodišnje uskolisne (divlji sirak iz rizoma, pirika) i neke širokolisne korove. Kao i kod nikosulfurona jednogodišnje trave ne smiju imati više od 5 listova! Za razliku od nikosulfurona ima određeno djelovanje i preko tla. Preporučuje se dodavanje neionskih okvašivača: Trend 90, Citowett i sličnih u škropivo (u spremnik prksalice idu zadnji).

$\mathrm{LD}_{50}>$ 5000. S.O. = III.

\subsubsection{Tifensulfuron-metil}

Pripravci na bazi tifensulfuron-metila su selektivni post-em. herbicidi namijenjeni za suzbijanje širokolisnih korova u usjevu kukuruza od 2-5 lista i soji od 1-3 troliske dok su korovi u fazi od 2-4 lista. Rabi se za suzbijanje širokolisnih korova, i nekih prema atrazine rezistentnih korova (Amaranthus retroflexus, Chenopodium album, Ambrosia artemisiifolia,Abutilon theophrasti) u kukuruzu i soji.

$$
\mathrm{LD}_{50} \text { 5000. S.O. = III. K - OVP. }
$$

\subsubsection{Tribenuron}

Pripravci na bazi tribenurona su selektivni herbicidi namijenjeni za suzbijanje širokolisnih korova u usjevima strnih žitarica. Kratke su perzistentnosti i ne ograničavaju plodosmjenu niti nakon proljetne primjene. Mogu se koristiti i u kraškim područjima. Proizvođač preporučuje kombinaciju Granstar 15-20 g/ha i Starane 250 EC 0,4-0,5 1/ha sve do pojave drugog koljenca $\mathrm{u}$ pšenici. Već 1 sat nakon prskanja cjelokupna količina pripravka je u biljci i nema mogućnosti ispiranja padalinama.

$\mathrm{LD}_{50}$ 5000. S.O. = III.

\subsubsection{Triflusulfuron}

Pripravci na bazi triflusulfurona su selektivni post-em. herbicidi namijenjeni za suzbijanje jednogodišnjih širokolisnih korova u usjevu šećerne i stočne repe.

Suzbijaju i Abutilon theophrasti. Kratkog su rezidualnog djelovanja. Treba ih primijeniti više puta tijekom vegetacije u kombinaciji s mineralnim uljem ili Herbovit 90 / Trend 90.

Zbog proširenja spektra rabe se s pripravcima na osnovi: fenmedifama, etofumesata, desmedifama, klopiralida, metamitrona i kvizalofop. Dozu je potrebno prilagoditi vrsti, broju i stadiju razvoja korova. Već 3 sata nakon prskanja djelatna tvar je u cijelosti u biljci i nema mogućnosti ispiranja padalinama. Neučinkoviti su na Chenopodium spp.

$\mathrm{LD}_{50}>$ 5000. S.O. = III. K - OVP. Korovi trebaju biti u fazi od kotiledona do 2 prava lista! 


\subsubsection{Tritosulfuron}

Pripravak na bazi tritosulfurona je selektivni herbicid namijenjen za suzbijanje velikog broja jednogodišnjih i višegodišnjih širokolisnih korova u usjevu ozimih i jarih žitarica. Pri primjeni je potrebno dodati okvašivač.

S.O. = III. K - OVP osim 70 dana kukuruz za silažu (Callam).

\subsubsection{Mesosulfuron}

Sistemični herbicid za suzbijanje jednogodišnjih travnih i jednogodišnjih širokolisnih korova u žitaricama.

Pripravci: Alister grande, Alister new, Atlantis star.

\subsection{Imidazolinoni}

Imidazolinoni imaju isti mehanizam djelovanja kao i herbicidi iz grupe sulfonilurea, odnosno i oni kod osjetljivih biljaka inhibiraju rad enzima acetolaktat sintetaze (ALS) zbog čega u biljci izostaje biosinteza esencijalnih aminokiselina: valina, leucina i izoleucina, na temelju čega su razvrstani u HRAC grupu B. Biljka ih usvaja preko korijena i preko lista. Iako se primjenjuju u vrlo niskim dozama, mnogi od njih su vrlo perzistentni zbog čega se u tlu njihove biološki aktivne rezidue mogu pronaći i nekoliko godina nakon tretiranja. Upravo zbog perzistentnosti i posljedica koje proizlaze zbog perzistentnosti, mnogi herbicidi iz ove skupine u mnogim zemljama svijeta su od nedavno zabranjeni.

Jedini herbicid iz ove skupine koji ima široko područje primjene je imazamoks koji se koristi za suzbijanje jednogodišnjih uskolisnih i širokolisnih korova nakon nicanja usjeva i korova u usjevima soje, graha, graška i lucerne. Imidazolinoni nisu pretjerano toksični za toplokrvne organizme zbog čega su razvrstani u treću skupinu otrova. U SAD-u i nekim zemljama Europe su selekcijom kulture stanica uzgojeni hibridi suncokreta i sorte soje tolerantni na imidazolinon herbicide.

\subsubsection{Imazamoks}

Djelatna tvar izaziva inhibiciju enzima acetolaktat sintaze (ALS) odgovornog za sintezu esencijalnih aminokiselina: valina, leucina i izoleucina. Zaštitu obaviti kada su soja, grah i grašak u fazi od 1-3 troliske, a lucerna u fazi tri troliske. Manje perzistentan od drugih djelatnih tvari iz ove grupe. Spektar suzbijanja: jednogodišnji širokolisni korovi, višegodišnji širokolisni korovi, trave.

$\mathrm{LD}_{50}$ 5000. S.O. = III.

\subsection{Triazolopirimidini}

(engl. Triazolopyrimidine)

Triazolopirimidini imaju isti mehanizam djelovanja kao i herbicidi iz grupe sulfonilurea $i$ imidazolinona, odnosno i oni kod osjetljivih biljaka inhibiraju rad enzima acetolaktat sintetaze (ALS) zbog čega u biljci izostaje biosinteza esencijalnih aminokiselina: valina, leucina i 
izoleucina, na temelju čega su razvrstani u HRAC grupu B.

Triazolopirimidini su novija skupina herbicida koji se koristi za suzbijanje širokolisnih korova u usjevu strnih žitarica u vrlo niskim količinama po jedinici površine. Biljka ih usvaja preko korijena i preko lista. Perzistentni su u tlu te u određenoj mjeri ograničavaju plodored.

\subsubsection{Florasulam}

Djelatna tvar izaziva inhibiciju enzima acetolaktat sintaze (ALS/AHAS) odgovornog za sintezu lančanih aminokiselina: valina, leucina i izoleucina. Pripravak namijenjen suzbijanju širokolisnih korova u svim usjevima ozimih i jarih žitarica.

$\mathrm{LD}_{50}>6000$. S.O. $=$ III. K - OVP.

\subsubsection{Piroksulam}

Piroksulam je post-em herbicid namijenjen suzbijanju širokog spektra jednogodišnjih uskolisnih i širokolisnih korova u žitaricama.

$\mathrm{LD}_{50}>2000$.

\subsection{Triazoloni}

(engl. Triazolone)

\subsubsection{Tienkarbazon-metil}

Djelatna tvar izaziva inhibiciju enzima acetolaktat sintaze (ALS/AHAS) odgovornog za sintezu lančanih aminokiselina: valina, leucina i izoleucina. Biljka ga apsorbira korijenom i listom, ima kontaktno i rezidualno djelovanje. Pripravak namijenjen suzbijanju jednogodišnjih korova u žitaricama.

$\mathrm{LD}_{50}>2000$. S.O. $=$ III.

\subsection{Triazini}

(engl. Triazine)

Triazini kod osjetljivih biljaka inhibiraju fotosintezu u fotosistemu II, u kloroplastima tilakoidnih membrana, što dovodi do blokiranja transporta elektrona od QA do QB, a što rezultira zaustavljanjem fiksacije $\mathrm{CO} 2$ i produkcije ATP i NADPH2 potrebnih za normalni porast biljke. Na osnovu navedenog mehanizma djelovanja triazini su razvrstani u HRAC grupu C1. Ove herbicide biljka apsorbira iz tla preko korijena, poslije čega se oni transportiraju ksilemom u zelene dijelove gdje djeluju u kloroplastima ometajući normalni tok fotosinteze. Simptomi toksičnog djelovanja triazina vidljivi su u vidu intervenoznih kloroza i žutila na rubu lista, poslije čega se kod osjetljivih biljaka pojavljuje kloroza i nekroza.

Triazini su relativno stara, ali vrlo značajna i relativno jeftina grupa herbicida širokog spektra djelovanja na dikotiledone korove. Općenito, triazini su skloni adsorpciji zbog čega su mnogi od njih u tlu perzistentni. Prosječne doze razgrade se za 4-6 mjeseci. Daleko najznačajniji predstavnik ove grupe bio je atrazin koji se masovno rabio u zaštiti kukuruza od korova. Ipak, posljednjih godina zbog pooštrenih propisa (maksimalno dopuštena količina u pitkoj vodi iznosi 
$0,1 \mathrm{ppb})$ i zbog široke primjene, pojedini triazini, a naročito atrazin, mogu se naći u pitkoj vodi u količinama većim od dopuštenih propisom. Upravo zbog tog razloga u mnogim zemljama svijeta mnogi triazini, a naročito atrazin, su zabranjeni ili im je ograničena uporaba i doze.

U svijetu je veliki broj korovnih vrsta razvio rezistentne biotipove na ovu skupinu herbicida.

\subsubsection{Terbutilazin}

Djelatna tvar izaziva inhibiciju procesa fotosinteze. Rabi se u suzbijanju jednogodišnjih šrokolisnih korova u usjevu kukuruza bez podusjeva (za zrno i silažu) poslije sjetve, a prije nicanja, ranom postu i u nasadima voćaka i vinove loze starijim od 2 godine u proljeće $u$ suzbijanju sjemenskih korova. U tlu je manje ispirljiv od atrazina i služi kao alternativa u izboru zemljišnih pripravaka u kukuruzu. Mehanizam djelovanja i ciljana mjesta djelovanja istovjetna su atrazinu. U ranom postu (do 2-3 lista kukuruza) učinkovitost poboljšava dodatak 1-2 1/ha bijelog ulja. Nakon berbe kukuruza ne smije se sijati uljana repica, lucerna i djetelina.

$\mathrm{LD}_{50} 2100$. S.O. = III. K - OVP za kukuruz za zrno i mliječna zrioba za kukuruz za zrno.

\section{9 . Triazinoni}

(engl. Triazinone)

Triazinoni imaju isti mehanizam djelovanja kao i herbicidi iz grupe triazina, uracila, piridazinona ifenil-karbamata odnosno i oni kod osjetljivih biljaka inhibiraju proces fotosinteze $\mathrm{u}$ fotosistemu II, zbog čega u tretiranoj osjetljivoj biljci izostaje fiksacija CO2 i produkcija ATP i NADPH2, a koji su neophodni za normalni porast biljke, na temelju čega je i ova grupa herbicida razvrstana u HRAC grupu C1.

Triazinoni su vrlo učinkoviti pre-em. i post-em. herbicidi. Suzbijaju širokolisne, ali i neke uskolisne korove, dok su na višegodišnje korove neučinkoviti. Redovito se rabe u kombinaciji s herbicidima djelotvornim za suzbijanje travnih korova. Triazinoni su nesimetrični triazini, kod kojih je perzistentnost u tlu nešto kraća od većine simetričnih triazina i iznosi 3-6 mjeseci.

Pripravci na osnovi metribuzina se koriste u soji, krumpiru, rajčici, lucerni i suncokretu, dok se pripravci na osnovi metamitrona rabe u usjevu šećerne i stočne repe. Određene sorte krumpira i soje pokazuju sortnu osjetljivost prema metribuzinu.

\subsubsection{Metamitron}

Djelatna tvar izaziva inhibiciju procesa fotosinteze. Zemljišni (rezidualni) i folijarni (kontaktni) pripravak za suzbijanje jednogodišnjih širokolisnih korova, izrazite selektivnosti za kulturu. Uporaba: pre-em. ili višekratno u post-em. u usjevu šećerne i stočne repe.

$\mathrm{Na}$ varijantu prskanja poslije sjetve, a prije nicanja treba se odlučiti kada očekujemo jaču pojavu korova prije nicanja repe i u dovoljno vlažnim tlima. Dozu odrediti prema sadržaju humusa te spektru i uzrastu korova. Izvanredno selektivan jer i nekoliko puta veće doze od preporučenih ne ostavljaju nikakve štete na repi. Suzbija većinu jednogodišnjih širokolisnih korova, osim Galium aparine, Polygonum convolvulus, Mercurielis annua i nekih jednogodišnjih travnih korova. U postu prskanja obaviti u kotiledonskom stadiju korova kada zadovoljavaju i niže doze metamitrona uz dodatak ulja. $\quad \mathrm{LD}_{50} 3300$. S.O. $=$ III. $\mathrm{K}-$ OVP. 


\subsubsection{Metribuzin}

Djelatna tvar izaziva inhibiciju procesa fotosinteze. Selektivni pripravak za suzbijanje velikog broja jednogodišnjih širokolisnih i nekih uskolisnih korova. Usvaja se korijenom (pre-em.) i listom (post-em.). U usjevu krumpira se primjenjuje nakon sadnje i formiranja humaka ili tijekom vegetacije. U usjevu rajčice iz direktne sjetve se koristi u dozi od $0,3 \mathrm{~kg} / \mathrm{ha}$ prije nicanja i 0,4-0,7 kg/ha u fazi 4-6 lista rajčice. U lucerni se koristi u vrijeme mirovanja ili prije kretanja vegetacije. Doze je potrebno prilagoditi sadržaju humusa u tlu, pri čemu se niže doze rabe na srednje teškim, a veće na teškim, humusom bogatijim tlima. U sušnom periodu učinkovitost metribuzina je znatno manja.

$\mathrm{LD}_{50}$ 2200. S.O. $=$ III.

\subsection{Piridazinoni}

(engl. Pyridazinone)

Piridazinoni imaju isti mehanizam djelovanja kao i herbicidi iz grupe triazina, triazinona, uracila ifenil-karbamata, odnosno i oni kod osjetljivih biljaka inhibiraju proces fotosinteze u fotosistemu II, zbog čega u biljci izostaje fiksacija $\mathrm{CO} 2$ i produkcija ATP i NADPH2, koji su neophodni za normalni porast biljke, na temelju čega su i oni razvrstani u HRAC grupu C1.

Piridazinoni su relativno stara skupina herbicida koja se odlikuje dobrom efikasnošću za suzbijanje jednogodišnjih sjemenskih širokolisnih korova. Na korove djeluju u nicanju preko korijenovog sustava ili preko lista kod primjene u vegetaciji. Iz ove skupine na tržištu su prisutni kloridazon koji se već dugo godina rabi za suzbijanje korova u usjevu šećerne i stočne repe i blitve te piridat. Selektivan je u sva tri roka primjene. Redovito se rabi u kombinaciji s drugim herbicidima. Pogodan je pripravak za višekratnu primjenu sa umanjenim količinama. Iskazuje osrednju perzistentnost (4-8 tjedana).

\subsubsection{Kloridazon}

Djelatna tvar izaziva inhibiciju procesa fotosinteze svojstvenu svim zelenim biljkama kojim svjetlosnu energiju sunca pretvara u šećere. Selektivni, zemljišni rezidualnokontaktni pripravak za suzbijanje jednogodišnjih sjemenskih širokolisnih korova u usjevu repe u pre- i post-em.-u. Učinak u velikoj mjeri ovisi o vlazi u tlu. Na korove djeluje u nicanju preko korijenovog sustava ili preko lista kod primjene u vegetaciji. Korovi su najosjetljiviji u fazi nicanja. Dozu prilagoditi sadržaju humusa u tlu. S više od 2 para pravih listova učinkovitost kloridazona se bitno smanjuje. Najbolje prskanje obaviti 3-5 dana prije nicanja repe na dobro pripremljenom tlu. Proizvođač ga preporučuje i u luku u više odvojenih rokova primjene u smanjenim dozama.

LD $_{50} 3300$. S.O. = III. K - OVP osim za ciklu - 93 dana.

Lišće stočne repe smije se koristiti 70 dana poslije tretiranja.

\subsubsection{Piridat}

Djelatna tvar se koristi za suzbijanje jednogodišnjih širokolisnih korova u ratarskim kulturama te povrtnicama nakon nicanja/presađivanja kulture. Bolji rezultati postižu se kod višekratne primjene. 


\subsection{Fenil-karbamati \\ (engl. Phenyl-carbamate)}

Fenil-karbamati imaju isti mehanizam djelovanja kao i herbicidi iz grupe triazina, triazinona, uracila i piridazinona, odnosno i oni kod osjetljivih biljaka inhibiraju proces fotosinteze u fotosistemu II, zbog čega u biljci izostaje fiksacija CO2 i produkcija ATP i NADPH2, koji su neophodni za normalni porast biljke, na temelju čega su i oni razvrstani u HRAC grupu C1. Iz ove skupine na tržištu su prisutne djelatne tvari dezmedifam i fenmedifam koji se rabe u usjevima šećerne repe i blitve za suzbijanje jednogodišnjih širokolisnih korova. Slabo su perzistentni. Budući da su jedni od vodećih herbicida za suzbijanje korova u usjevu šećerne repe, na njihovoj osnovi i u kombinaciji s drugim herbicidima (etofumesat), na tržištu postoji veći broj registriranih pripravaka.

\subsubsection{Desmedifam}

Djelatna tvar izaziva inhibiciju procesa fotosinteze. Kontaktnog je djelovanja, učinkovita na korove iz fam. Amaranthaceae i veliki broj drugih širokolisnih korova. Ako je šećerna repa u fazi kotiledona, primijenjene količine pripravaka ne smiju biti veće od 1 1/ha. Prvi tretman protiv korova se obavlja kada je većina korova u fazi kotiledona uz uvijet da repa ima dva prava lista, ali se to u praksi često provodi i znatno ranije. Nakon 5-10 dana tretman se ponavlja kada je većina korova u fazi kotiledona.

\section{LD $50>$ 5000. S.O. = III.}

\subsubsection{Fenmedifam}

Djelatna tvar izaziva inhibiciju fotosinteze svojstvenu svim zelenim biljkama kojim svjetlosnu energiju sunca pretvara u šećere. Kontaktni herbicid za uporabu u kombinaciji s drugim djelatnim tvarima u suzbijanju jednogodišnjih širokolisnih korova u mlađem razvojnom stadiju. Za učinkovito djelovanje pripravaka potrebno je da 3-4 sata nakon prskanja ne bude padalina. Kod OF pripravka to vrijeme je 1-2 sata, a za Betanal AM-11 New najmanje 6 sati!

$\mathrm{LD}_{50}$ 8000. S.O. $=$ III.

\subsection{Uree (supstituirani derivati fenilurea) (engl. Urea)}

Herbicidi iz grupe urea kod osjetljivih biljaka inhibiraju proces fotosinteze u fotosistemu II, zbog čega su razvrstani u HRAC grupu C2. Ovi herbicidi primarno djeluju preko korijena, odakle se putem vode translociraju sve do listova gdje se vežu na kloroplast i ometaju proces fotosinteze zbog čega dolazi do ugibanja osjetljivih korovnih biljaka. Primjenjuju se nakon sjetve, ali i nakon nicanja. Čvrsto se vežu na čestice tla. Slabo podliježu ispiranju zbog čega su relativno perzistentni. Razgrade se u toku 3-6 mjeseci. Maksimalna koncentracija sredstva zadržava se u površinskom sloju tla odakle ga biljka apsorbira korijenom. Selektivnost im se zasniva na prostornoj razlici između na površinu tla nanijetog filma herbicida i dubine položenog sjemena kulture (prostorna selektivnost). 
Herbicidi iz grupe urea su relativno starija, ali vrlo značajna skupina herbicida. Širokog su spektra djelovanja na veliki broj korova, ali ne djeluju na višegodišnje korove. Male su otrovnosti zbog čega su svi razvrstani u treću skupinu otrova. Klortoluron i izoproturon su već duži niz godina vodeći herbicidi na području suzbijanja travnih korova u strnim žitaricama. Radi proširenja spektra na neke širokolisne korove, rabe se zajedno s herbicidima iz drugih skupina. Linuron se sam ili u kombinaciji s drugim herbicidima rabi u kukuruzu, krumpiru, suncokretu, soji i mrkvi.

\subsubsection{Klortoluron}

Djelatna tvar izaziva inhibiciju procesa fotosinteze svojstvenu svim zelenim biljkama kojim svjetlosnu energiju sunca pretvara u šećere. Rabi se za suzbijanje jednogodišnjih travnih i nekih širokolisnih korova. Primjenjuje se prije ili poslije nicanja ozimih usjeva tijekom jeseni ili u proljeće sve do konca busanja. Prskanje jarih žitarica se ne preporučuje kao ni kasno posijanih ozimina, u vrijeme jakih mrazeva i na lakim tlima s manje od 1,2\% humusa. Korovna biljka ga usvaja korijenom i listom. Najčešće u kombinaciji s djelatnim tvarima za suzbijanje širokolisnih korova.

LD $_{50}$ 10000. S.O. = III. K - OVP.

\subsubsection{Linuron}

Djelatna tvar izaziva inhibiciju procesa fotosinteze. U slučaju većih padalina nakon primjene moguće su fitotoksične pojave na klijancima budući da je samo "prostorno" selektivan. Zemljišni i folijarni (u manjoj mjeri) pripravak za suzbijanje širokolisnih korova u velikom broju kultura. Korovna biljka ga usvaja i korijenom i listom. Za dobar učinak potrebna je dobra predsjetvena priprema i vlaga u tlu. Do odumiranja korova dolazi tijekom 8-14 dana. U biljci se kreće akropetalno. Nije za uporabu na tlima s manje od 1,5\% i više od $6 \%$ humusa. Ne rabiti u mladoj mrkvi namijenjenoj prodaji.

$$
\text { LD }_{50} 1500 \text { - 4000. S.O. = III. }
$$

\subsubsection{Metobromuron}

Djelatna tvar za suzbijanje jednogodišnjih širokolisnih i travnih korova. Ima dozvolu za suzbijanje korova u pre-em roku primjene u krumpiru. U slučaju propadanja usjeva, na tlu na kojem je primijenjeno sredstvo, uz zaoravanje na dubinu $15-20 \mathrm{~cm}$ smiju se sijati ili saditi korjenasto i/ili lisnato povrće, nakon mjesec dana kukuruz, mrkva, grah, mahune, grašak i suncokret; nakon 6 mjeseci: žitarice; nakon $12 \mathrm{mj}$. ostale kulture.

$\mathrm{LD}_{50}>10000, \mathrm{~K}-\mathrm{OVP}$

\subsection{Nitrili (benzonitrili)}

(engl. Nitrile)

Nitrili predstavljaju heterogenu i relativno stariju skupinu kontaktnih herbicida s izvjesnim translokacijskim djelovanjem. Bromoksinil kod osjetljivih biljaka inhibira proces fotosinteze u fotosistemu II, zbog čega je on razvrstan u HRAC grupu C3. 
Suzbija isključivo širokolisne korove, naročito kad se nalaze u mlađem razvojnom stadiju. Selektivan je u kukuruzu i strnim žitaricama.

Iako je građom jako sličan bromoksinilu, diklobenil se po svojim biološkim karakteristikama bitno razlikuje od njega pošto kod osjetljivih biljaka inhibira građu staničnih stijenki, a ima utjecaj i na sintezu enzima celuloze, zbog čega je razvrstan u HRAC grupu L. Hlapiv je pa na tržište dolazi isključivo u formi granulata. Diklobenil biljka apsorbira korijenom i preko lista. Herbicid je širokog spektra. Perzistentan je 6-12 mjeseci (ovisno o dozi). Rabi se kao selektivni herbicid u vinovoj lozi, kruški, breskvi, malinama i ribizu, te kao totalni herbicid u ukrasnom šiblju, grmlju, živicama, na putovima, grobljima i slično.

\subsubsection{Bromoksinil}

Djelatna tvar izaziva inhibiciju fotosinteze svojstvenu svim zelenim biljkama kojim svjetlosnu energiju sunca pretvara u šećere. Fitotoksičan kada se primjenjuje s uljem i na višim temperaturama od $22^{\circ} \mathrm{C}$ ili u vlažnim uvjetima. Relativno nizak $\mathrm{LD}_{50}$ ! Selektivni kontaktni pripravak za suzbijanje jednogodišnjih širokolisnih korova u usjevu kukuruza. Kukuruz u vrijeme primjene treba biti od 2-4 lista, a korovi od 4-6. Kompatibilan s većinom pripravaka. Ne prskati po hladnom, vjetrovitom i kišovitom vremenu. Potrebno 6 sati od tretiranja bez padalina da bi se pripravak u cijelosti usvojio.

$\mathrm{LD}_{50}$ 190. S.O. = II. K - 60 dana kukuruz za zrno i silažu, 45 dana kukuruz šećerac, OVP za luk.

\subsection{Benzotiadiazinoni}

(engl. Benzothiadiazinone)

Benzotiadiazinoni su nešto starija skupina herbicida koja kod osjetljivih biljaka inhibira proces fotosinteze u fotosistemu II, zbog čega su razvrstani u HRAC grupu C3. Koriste se za suzbijanje jednogodišnjih širokolisnih korova, a njihov jedini predstavnik je bentazon. Ovaj herbicid je kontaktnog djelovanja. Apsorbira se lišcem i minimalno se bazipetalno translocira poslije folijarne primjene. Maksimalna količina se apsorbira 4 sata poslije upotrebe ili za još kraće vrijeme ako se upotrebi sa adjuvantom. Kod razvijenih biljaka bentazon se apsorbira i korijenom iz hranjivog medija i transportira u nadzemene dijelove biljke. Kloroza se pojavljuje 3-5 dana poslije primjene, poslije čega dolazi do nekroze i otpadanja osušenih listova. U tlu se bentazon razgrađuje relativno brzo. Polovični vijek raspada iznosi mu 20 dana. Tolerantne biljke ga brzo metaboliziraju formirajući glukozil konjugate koji su manje pokretljivi i toksični za tretiranu biljku. Selektivan je u kukuruzu i mahunarkama (soji, grahu, grašku i lucerni). Rezidue bentazona u biljnom materijalu razgrade se unutar 6 tjedana. Rabi se sam, ali i u kombinaciji s drugim herbicidima.

\subsubsection{Bentazon}

Djelatna tvar izaziva inhibiciju fotosinteze svojstvenu svim zelenim biljkama kojim svjetlosnu energiju sunca pretvara u šećere. Djeluje isključivo preko zelenih (živih) biljnih dijelova. Ugrađuje se u klorofil i remeti proces fotosinteze. Zeleni dijelovi korova postupno žute i nakon nekoliko dana potpuno se osuše. Nekroza nastaje u neposrednoj zoni kontakta kapljice 
škropiva i površine lista. Translokacija djelatne tvari kroz biljku je minimalna, zbog čega svi biljni dijelovi moraju biti dobro poprskani škropivom. Viša relativna vlaga zraka i temperatura pojačavaju učinkovitost pripravka. Kukuruz i sirak su potpuno tolerantni na bentazon u svim fenofazama razvoja. Učinkovit je na korove u fazama od 2-6 listova. Nakon prskanja ne smije padati kiša barem 6 sati. Ne prskati pri jakim rosama, zbog mogućnosti ispiranja. Može se primijeniti i u split aplikaciji u intervalu od 10-15 dana. Suncokret u vrijeme suzbijanja ne bi smio imati više od 4 lista. Za soju je potpuno selektivan ako se primjenjuje nakon prve troliske do pred cvatnju soje, a u krumpiru po obavljenom zagrtanju kada je $10-15 \mathrm{~cm}$ visine na nikle korove. Ne u kombinaciji s folijarnim graminicidima! Proizvođač ga preporučuje i u luku u više odvojenih rokova primjene u smanjenim dozama tijekom vegetacije. $U$ tlu se razgradi uz pomoć mikroorganizama nakon mjesec dana. Ne veže se na čestice tla. Brza razgradnja onemogućava njegovu akumulaciju u površinskim i podzemnim vodama. Slabo hlapljiv i neznatno opasan po susjedne osjetljive usjeve. Opasnost se povećava dodatkom okvašivača škropivu. Neznatne akutne toksičnosti za životinje. Prvi simptomi na tretiranim korovima vidljivi su nakon 2-7 dana od primjene.

$$
\mathrm{LD}_{50} 6000, \text { S.O. }=\text { III. }
$$

\title{
1.15. Dipiridili
}

\author{
(engl. Bipyridylium)
}

Dipiridili su mala, ali vrlo važna skupina post-em. kontaktnih neselektivnih herbicida koji kod osjetljivih biljaka inhibiraju proces fotosinteze preusmjeravajući elektrone iz fotosistema I pri čemu se formiraju superoksidi, koji oštećuju stanične membrane i citoplazmu, zbog čega su razvrstani u HRAC grupu D. Ovi herbicidi pri dodiru uništavaju sve zelene dijelove biljke sa kojima dođu u kontakt, zbog čega se često rabe kao desikanti. Vrlo brzo se folijarno apsorbiraju, tako da kiša već 30 minuta poslije primjene ne izaziva ispiranje preparata. Transportiraju se skoro isključivo ksilemom. Folijarna apsorpcija se poboljšava dodavanjem neionskih okvašivača.

Glavna osobina ove grupe je njihova brza inaktivacija u kontaktu s tlom, zbog čega je neposredno nakon njihove primjene moguće sijati bilo koju kulturu bez ikakva ograničenja. Zbog potpune inaktivacije u tlu i širokog spektra djelovanja na korove ovi herbicidi su bili sinonim pripravaka za „kemijsko oranje“ ili zamjena klasičnoj obradi oranjem i pripremi tla prije sjetve, zbog čega su u svijetu znatno pripomogli uvođenju minimalne i reducirane obradbe tla. Osim kao totalni, usmjerenom aplikacijom pod list širom svijeta se koristi u vinogradima i voćnjacima kao selektivni herbicidi. Zbog pozitivnih karakteristika, već duži niz godina vodeći su herbicidi u svijetu. Međutim, dipiridili su vrlo opasna sredstva. Za parakvat (Gramoxone) do danas nije pronađen protuotrov. Širom svijeta zabilježena su namjerna i slučajna trovanja, sva sa smrtnim posljedicama. 


\subsubsection{Dikvat}

Djelatna tvar izaziva brzo razaranje staničnih stijenki stvaranjem vrlo toksičnih spojeva usko povezanih s fotosintezom. Vrlo topljiv u vodi. Snažno se veže na čestice glinasto ilovastih tala. Vrlo toksičan za sisavce. Razgradnja se najvećim dijelom odvija uz pomoć ultraljubičastog zračenja, a utjecaj mikroorganizama neznatan. Pripravak za uporabu u suzbijanju velikog broja jednogodišnjih uskolisnih i širokolisnih korova; za desikaciju sjemenskog i merkantilnog krumpira, soje (14 dana prije berbe), suncokreta, uljane repice (najkasnije 14 dana prije žetve), lucerne i djeteline (u zriobi). Djeluje kontaktno i vrlo brzo. Desikaciju obaviti u vrijeme biološke zrelosti usjeva.

$\mathrm{LD}_{50}$ 231. S.O. = II (preko 20\% djelatne tvari); inače III.

\subsection{Difenileteri}

(engl. Diphenylether)

Herbicidi iz grupe difeniletera kod osjetljivih biljaka uzrokuju inhibiciju enzima protoporfirinogen oksidaze (PPO) odgovornog za biosintezu klorofila koji katalizira oksidaciju protoporfirenogena (PPGIX) u protoporfirin (PPIX), što izaziva oštećenja stanične membrane i na kraju ugibanje osjetljive biljke, zbog čega su razvrstani u HRAC grupu E. Predstavljaju grupu herbicida širokog spektra djelovanja na jednogodišnje širokolisne korove. Kontaktnog su učinka, zbog čega ih dominantno primjenjujemo nakon nicanja korova. Vrlo brzo se apsorbiraju lišćem biljaka pa minimalni gubici nastaju poslije kiše 1 sat poslije primjene. Primarno se trasnportiraju ksilemom. Bolje djeluju na širokolisne korove, iako iskazuju izvjesne učinke i na klijance trava. Djeluju i preko korijena, no tad ih je potrebno primijeniti u višim dozama.

Jedini predstavnik ove grupe je selektivni kontaktni herbicid oksifluorfen koji je namijenjen suzbijanju korova u usjevu suncokreta, luka, kupusa i cvjetače, te voćnjacima i vinogradima. Difenil eteri se vrlo čvrsto vežu na adsorpcijski kompleks tla te se gotovo ne pomiču s površine tla. Perzistentnost u tlu im je različita. Rezidue oksifluorfena mogu osjetljivim kulturama štetiti i naredne sezone.

\subsubsection{Oksifluorfen}

Djelatna tvar izaziva inhibiciju enzima protoporfirinogen oksidaze (PPO) i kidanje stanične stijenke korovne biljke. Kontaktni, selektivni i rezidualni zemljišni pripravak za suzbijanje širokolisnih korova. Obično se rabi u kombinaciji s drugim djelatnim tvarima. Dobra predsjetvena priprema i kvalitetna aplikacija stvara herbicidni "film" koji uništava klijajuće korove. Ne ulazi u biljku i ne translocira u njoj. Na suncokretu izaziva prolazne fitotoksične simptome. Dopuštena jedna primjena godišnje.

$$
\mathrm{LD}_{50} \text { 5000. S.O. = III. }
$$




\subsection{7. $N$-fenilftalimidi}

(engl. N-phenylphthalimide)

$\mathrm{N}$-fenilftalimidi imaju isti mehanizam djelovanja kao i herbicidi iz grupe difeniletera i oksadiazola, odnosno i oni kod osjetljivih biljaka izazivaju inhibiciju enzima protoporfirinogen oksidaze (PPO, odgovornog za biosintezu klorofila, koji katalizira oksidaciju protoporfirenogena (PPGIX) u protoporfirin (PPIX), što izaziva oštećenja stanične membrane i na kraju ugibanje osjetljive biljke, zbog čega su i oni razvrstani u HRAC grupu E.

$\mathrm{N}$-fenilftalimidi su nešto novija skupina herbicida koji se koriste za suzbijanje širokolisnih korova. Vrlo brzo se apsorbiraju lišćem biljaka mada mogu biti apsorbirani i korijenovim sustavom. Primarno se transportiraju ksilemom. Listovi osjetljivih biljaka poslije tretiranja u početku postaju klorotični, poslije čega nekrotiziraju i opadaju za 1-3 dana.

\subsubsection{Flumioksazin}

Djelatna tvar izaziva inhibiciju enzima protoporfirinogen oksidaze (PPO), odgovornog za sintezu jednog od međuproizvoda klorofila. Pripravak namijenjen suzbijanju jednogodišnjih širokolisnih korova u usjevima sucokreta i kukuruza nakon sjetve, a prije nicanja te u vinogradima starijima od 4 godine.

Smije se primijeniti najkasnije 48 sati nakon sjetve. Za proširenje spektra djelovanja na jednogodišnje travne korove kombinira se pripravcima učinkovitim na iste.

Djeluje kao inhibitor protoporfirinogen oksidaze.

$\mathrm{LD}_{50}>$ 5000. S.O. $=$ III. K - OVP.

\subsection{Piridinkarboksamidi}

(engl. Pyridinecarboxamide)

Herbicidi iz grupe piridinkarboksamida kod osjetljivih biljaka inhibiraju biosintezu karotenoida blokiranjem aktivnosti enzima fiton desaturaze (PDS), zbog čega su razvrstani u HRAC grupu F1. Bez karotenoida koji imaju zaštitnu ulogu, molekule klorofila se vrlo brzo razgrade usljed čega novi listovi dobijaju bijelu ili svijetlo žutu boju ("Bleaching”), zbog čega osjetljive biljke na kraju ugibaju.

Piridinkarboksamidi se odlikuju kontaktnim i rezidualnim djelovanjem, a namijenjeni su suzbijanju širokolisnih i nekih uskolisnih korova u usjevu pšenice i ječma. Djelatna tvar se zadržava na površini tla tvoreći nevidljivi herbicidni film koji uništava klijance korova u nicanju.

\subsubsection{Diflufenikan}

Djelatna tvar izaziva inhibiciju enzima fiton desaturaze (PDS) odgovornog za sintezu karotenoida. Selektivni pripravak kontaktnog i rezidualnog djelovanja, namijenjen suzbijanju širokolisnih i nekih uskolisnih korova u usjevima pšenice i ječma. Može se rabiti poslije sjetve, a prije nicanja ili u postu od 2-3 lista do konca busanja. Listovi klijanaca koji su se razvili iz sjemena koje se u vrijeme prskanja ovim pripravcima nalazilo na površini tla prolazno mijenjaju boju u bijelu ili crvenu. Najčešće se rabi u kombinaciji s drugim djelatnim tvarima. 
LD $_{50}$ 2000. S.O. = III. T - 0,1 žitarice. K - OVP.

Pripravak: Alister Grande, Alister New, Tornado forte.

\subsection{Triketoni}

(engl. Triketone)

Herbicidi iz grupe triketona kod osjetljivih biljaka inhibiraju biosintezu karotenoida blokiranjem aktivnosti enzima 4-hidroksifenil-piruvat dioksigenaze (4-HPPD), zbog čega su razvrstani u HRAC grupu F2. Bez karotenoida koji imaju zaštitnu ulogu, molekule klorofila se vrlo brzo razgrade usljed čega novi listovi dobijaju bijelu ili svijetlo žutu boju ("Bleaching"), zbog čega osjetljive biljke na kraju ugibaju.

Triketoni su novija grupa herbicida vrlo dobre djelovanja za suzbijanje mnogih širokolisnih i nekih uskolisnih korova. U biljci su izrazito pokretljivi u oba smjera. U zemljištu su relativno perzistentni zbog čega za osjetljive biljke mogu predstavljati problem u plodoredu.

\subsubsection{Mezotrion}

Djelatna tvar izaziva inhibiciju enzima 4-hidroksifenil-piruvat dioksigenaze (4-HPPD) odgovornog za sintezu karotenoida. Bez karotenoida, koji imaju zaštitnu ulogu molekula klorofila, on se vrlo brzo razgradi te su novi listovi bijele ili svijetlo žute boje. Mezotrion je dobiven istraživanjem leptospermona, tvari izolirane iz ukrasne biljke Callistemon citrinus.

U biljci vrlo brzo kola u oba smjera. Nakon primjene na listovima se može pojaviti blijeđenje prolaznog karaktera i bez utjecaja na daljnji razvoj i prirod kukuruza.

Nakon primjene ne smiju se sijati dvije godine: šećerna i stočna repa, špinat, grah i grašak. Sjetva soje može se obaviti 12 mjeseci nakon primjene ovog pripravka. Na jesen iste godine smiju se sijati: pšenica, pšenoraž i ozimi ječam, a dublje preoravanje potrebno je obaviti prije sjetve uljane repice, lucerne ili djeteline. Učinkovit je u suzbijanju širokolisnih i malog broja uskolisnih korova. Za suzbijanje travnih korova treba koristiti neki od pre-em. graminicida. Kod primjene u postu obavezno dodati okvašivač. Nakon 3 lista kukuruza može se kombinirati s nikosulfuronom ili rimsulfuronom. Za 14 dana dolazi do ugibanjan tretiranih biljaka, a rast $\mathrm{i}$ razvoj korova nastupa odmah nakon prskanja. Omjer usvajanje listom i korijenom je $80: 20 \%$.

$\mathrm{LD}_{50}>5000$, S.O. III.

\subsubsection{Tembotrion}

Tembotrion izaziva inhibiciju enzima 4-hidroksifenil-piruvat dioksigenaze (4-HPPD) odgovornog za sintezu karotenoida. Bez karotenoida, koji imaju zaštitnu ulogu molekula klorofila, on se vrlo brzo razgradi te su novi listovi bijele ili svijetlo žute boje ("Bleaching"), zbog čega osjetljive biljke na kraju ugibaju.

Tembotrion je sistemični herbicid za suzbijanje jednogodišnjih travnih i jednogodišnjih širokolisnih korova u merkantilnom kukuruzu. Za poboljšanje učinka na širokolisne korove može se kombinirati sa herbicidima na temelju foramsulfurona. 


\subsection{Izoksazoli}

(engl. Isoxazole)

Izoksazoli imaju isti mehanizam djelovanja kao i herbicidi iz grupe triketona, odnosno i oni kod osjetljivih biljaka inhibiraju biosintezu karotenoida blokiranjem aktivnosti enzima 4hidroksifenil-piruvat dioksigenaze (4-HPPD), zbog čega su razvrstani u HRAC grupu F2. Bez karotenoida koji imaju zaštitnu ulogu, molekule klorofila se vrlo brzo razgrade usljed čega novi listovi dobivaju bijelu ili svijetlo žutu boju (blijeđenje), zbog čega osjetljive biljke na kraju ugibaju.

Izoksazoli predstavljaju noviju skupinu herbicida koji djeluju na jednogodišnje širokolisne korove, a slabije na jednogodišnje travne korove. Biljka ih apsorbira preko korijena. Izvjesni učinak iskazuju i na tek izniklim korovima. Umjerene su perzistentnosti. Trenutno jedini predstavnik ove grupe je izoksaflutol, koji se rabi u kukuruzu. Na tržište je plasiran kao zamjena za atrazin.

\subsubsection{Izoksaflutol}

Djelatna tvar izaziva inhibiciju enzima hidroksi fenil piruvat dioksigenaze (HPPD) odgovornog za sintezu karotenoida. Bez karotenoida, koja ima zaštitnu ulogu molekula klorofila se vrlo brzo razgradi te su novi listovi bijele ili svijetlo žute boje. Zemljišni pripravak namijenjen suzbijanju jednogodišnjih širokolisnih i (nekih) uskolisnih korova. Nakon usvajanja ksilemom i floemom translocira cijelom biljkom. Uporaba: poslije sjetve, a prije nicanja ili rani post-em. Najbolji rezultati postižu se primjenom na mlade korove u aktivnom rastu (od nicanja do 2 lista), a slabiji su u suši. Najbrže se očituje u meristemu zbog blockade sinteze pigmenata i bijeloj boji listova. U nekim zemljama registriran i za rani post-em. (do 3 lista kukuruza). Najčešće u kombinaciji s nekim od acetanilida. Učinkovit i u sušnim proljećima.

$\mathrm{LD}_{50}$ 5000. S.O. = III. K - OVP.

\subsection{Izoksazolidinoni}

(engl. Isoxazolidinone)

Herbicidi iz grupe izoksazolidinona kod osjetljivih biljaka inhibiraju biosintezu karotenoida blokiranjem aktivnosti enzima u putu biosinteze izoprenoida, mada im mehanizam djelovanja još uvijek nije u potpunosti razjašnjen, zbog čega su razvrstani u HRAC grupu F3. Bez karotenoida koji imaju zaštitnu ulogu, molekule klorofila se vrlo brzo razgrade usljed čega novi listovi dobijaju bijelu ili svijetlo žutu boju (“Bleaching”), zbog čega osjetljive biljke na kraju ugibaju.

Izoksazolidinoni predstavljaju relativno noviju skupinu herbicida koji djeluju na jednogodišnje travne i širokolisne korove. Trenutno jedini predstavnik ove grupe je klomazon, koji se primjenjuje prije sjetve soje ili sadnje duhana, dok se u usjevu uljane repice rabi nakon nicanja u relativno niskim dozama. U značajnijem stupnju klomazon se apsorbira korijenom i stabljikom klijanaca korova (koleoptilom kod travnih korova i hipokotilom i epikotilom kod širokolisnih korova). Slabo se apsorbiraju kada se folijarno primjeni. Poslije apsorpcije korijenom u nadzemne dijelove biljke se prenosi ksilemom. Također se slabo translocira 
floemom poslije folijarne primjene. Poslije nicanja mlade biljke su obično osjetljive prema ovom herbicidu, kada postaju bjeličaste i nekrotične. Drift (zanošenje) parama može izazvati blijeđenje listova obližnjih stabala, zeljastih kultura i općenito vegetacije.

\subsubsection{Klomazon}

Djelatna tvar izaziva inhibiciju više enzima sličnih (HPPD) odgovornih za sintezu karotenoida. Bez karotenoida, koja ima zaštitnu ulogu molekula klorofila se vrlo brzo razgradi te su novi listovi bijele ili svijetlo žute boje. Zanošenjem ili parama može izazvati na listovima prolazno bijeljenje ili žućenje susjednih kultura. Zemljišni pripravak za suzbijanje uskolisnih i nekih širokolisnih korova. Primjena poslije sjetve ili sadnje, a prije nicanja ili prije sjetve ili sadnje uz inkorporaciju. U biljkama izaziva inhibiciju sinteze pigmenata koji čuvaju molekulu klorofila od razornog djelovanja sunčanih zraka. Usvaja se korijenom i premješta ksilemom k vrhu biljke i difuzijom dospijeva u listove. Ne pokazuje sposobnost kretanja u suprotnom smjeru ili iz lista u list. Radi proširenja spektra koristi se u kombinaciji s drugim djelatnim tvarima. Perzistentan - voditi računa o plodosmjeni! Nakon 9 mjeseci od primjene dopuštena sjetva: kukuruza, graha, graška i sadnja rajčice; nakon 16 mjeseci: zobi, prosa, lucerne i rajčice iz sjemena; nakon 18 mjeseci: šećerne i stočne repe i nakon 12 mjeseci svih ostalih usjeva.

S.O. $=$ III. LD $_{50}$ 1406. K - OVP.

\subsection{Glicini (aminofosfonati)}

(engl. Glycine)

Herbicidi iz grupe glicina kod osjetljivih biljaka inhibiraju aktivnost enzima 5enolpiruvilšikimat-3-fosfat (EPSP)sintetaze koja producira EPSP iz šikimat-3-fosfata i fosfoenolpiruvata u metaboličkom putu šikimske kiseline. EPSP inhibira korištenje aromatičnih aminokiselina triptofana, tirozina i fenilalanina koje su neophodne za sintezu proteina ili za biosintetski put rasta, zbog čega su razvrstani u HRAC grupu G. Dodavanjem ovih aminokiselina egzogeno potpuno se zaustavlja toksičnost glifosata na više biljke što ukazuje da je inhibicija sinteze proteina involvirana u ove efekte. Sisavci nemaju EPSP enzim i svoje potrebe za ovim aminokiselinama zadovoljavaju drugim izvorima hrane.

Jedini predstavnik ove grupe je totalni herbicid glifosat, koji je izraziti sistemik, sa translokacijskim djelovanjem na jednogodišnje i višegodišnje korove. Ekotoksikološke karakteristike su mu vrlo povoljne. Ne ostavlja rezidue u tlu. Ne kontaminira vode, plodine. U procesu metabolizma glifosat se u biljkama polako metabolizira do aminometilfosfonske kiseline. Rabi se širom svijeta za totalno suzbijanje korova, zatim u višegodišnjim nasadima, vodotocima, na željezničkim prugama, putovima u naseljenim mjestima i sl. Masovno se rabi u genetski modificiranim biljkama. 


\subsubsection{Glifosat}

Djelatna tvar izaziva inhibiciju enzima 5-enolpiruvilšikimat-3-fosfat (EPSP)sintetaze odgovornog za sintezu aromatskih aminokiselina: fenilalanina, tirozina i triptofana. Ne selektivni izrazito sistemični-translokacijski pripravci za suzbijanje velikog broja jednogodišnjih travnih i širokolisnih korova te višegodišnjih korova s dubokim korijenom, rizomima i gomoljima. Najčešće se rabi u formi izopropilamino soli. Primjenjuje se na listove korova.

Snažno se veže na koloide tla u tolikoj mjeri da više nije pristupačan biljkama. U tlu se razgradnja najvećim dijelom odvija uz pomoć mikroorganizama, a manjim, kemijskim putem hidrolizom, oksidacijom i fotodegradacijom. Potrebno je šest sati iza primjene glifosata da bude suho jer u protivnom djelotvornost može biti smanjena.

$\mathrm{LD}_{50}$ 4320. S.O. = III. Neznatno toksičan za sisavce.

\section{Primjena uz utrošak vode na bazi 200-400 l/ha.}

Na strništima za suzbijanje: Agropyron repens, Sorghum halepense, Cynodon dactylon, Cyperus rotundus i sličnih u dozi 8-10 1/ha kada ovi korovi razviju lisnu masu i dostignu visinu 15-40 cm, pred cvatnju i u cvatnji kada je silazno kolanje asimilata najintenzivnije. Površine na kojima je primijenjeno sredstvo ne smiju se obrađivati najmanje 7 dana, a kod suzbijanja otpornih višegodišnjih korova 2-3 tjedna.

U vinogradima i voćnjacima ( jabuka, kruška, marelica, šljiva, višnja, maslina) u količini:

- 2-4 1/ha za suzbijanje jednogodišnjih korova

- 4-8 1/ha za suzbijanje višegodišnjih korova

- 8-12 1/ha za suzbijanje višegodišnjih korova s osobito dubokim korijenom ili rizomima u punoj vegetaciji.

U nasadu vinove loze se primjenjuje do završetka cvatnje, a u voćnjacima najkasnije u roku od 90 dana od početka cvatnje kada korovi imaju dobro razvijenu lisnu masu; tj. kod visine korova $15-40 \mathrm{~cm}$.

Smije se koristiti samo u nasadima starijim od 2 godine, odnosno ne smije se koristiti u voćnjacima i vinogradima dok je kora još zelena.

Za pred žetveno suzbijanje korova u žitaricama i za desikaciju uljane repice, tretiranjem najkasnije 14 dana prije žetve u dozi 2-4 1/ha. Slama s tretiranih površina ne smije se koristiti za kompost u proizvodnji povrća, gljiva i silažu.

Za obnovu livada i pašnjaka, tretiranjem u vrijeme intenzivnog rasta korova i livadnih trava $u$ dozi 2-4 1/ha za suzbijanje jednogodišnjih korova i 4-10 1/ha za suzbijanje višegodišnjih korova.

U suhim kanalima (III i IV reda) ili u povremeno plavljenim kanalima i močvarama koje se nakon odvodnje privode kulturi u dozi 4-8 1/ha uz napomenu da djelovanje pripravka traje od 1421 dan te se u tom periodu ne smiju kositi ili obrađivati. Voda se smije puštati u kanale najranije 7 dana nakon primjene.

$\mathrm{Na}$ neobrađenim površinama primjenom u vrijeme pune vegetacije u dozi 4-12 1/ha. Na željezničkim prugama za suzbijanje zeljastih i drvenastih korova u dozi 8-12 1/ha. 
U šumskim nasadima iz zrakoplova radi suzbijanja drvenastih korova: divljeg kestena, lijeske, gloga, topole, johe, bagrema, divlje ruže, kupine, borovnice, bazge, vrijesa, bukve, hrasta, graba, breze, vrbe i sl. u količini:

- 5-6 1/ha u nasadima bijelog i crnog bora uz utrošak vode od 75-100 1/ha.

- 6-7 1/ha u nasadima smreke uz utrošak vode od 75 1/ha.

- 7-8 1/ha kod pripreme površina za pošumljavanje uz utrošak vode od 75 1/ha.

- U šumskim rasadnicima tretiranjem između redova u vegetaciji uz obavezno korištenje štitnika u dozi 4,5 1/ha. Za primjenu koristiti uređaje niskog pritiska.

- U sadnicama smreke i bora u dozi 6 1/ha tretiranjem po cijeloj površini u vrijeme potpunog mirovanja četinjača, a rasta korova.

- U mladim nasadima četinjača za suzbijanje drvenastih korova:

- tretiranjem drvenastih korova tijekom vegetacije uz uporabu štitnika u koncentraciji od 2\%,

- tretiranjem po cijeloj površini početkom jeseni kada su sadnice u fazi završnog rasta u koncentraciji $1 \%$.

- Za suzbijanje izdanaka i izbojaka tretiranjem panjeva odmah nakon sječe stabala (svibanjprosinac) $15 \%$ otopinom.

- Poslije čiste sječe šume u pripremi površina za sadnju:

- tretiranjem izdanaka i izbojaka u punoj vegetaciji u period intenzivnog rasta u $1 \%$ koncentraciji.

- tretiranjem svježe posječenih panjeva u periodu kolovoz-rujan u $2 \%$ koncentraciji.

Količina pripravka ovisi o stupnju zakorovljenosti i vrsti korova. Za najvažnije vrste iznosi:

- 4 1/ha za Agropyron repens

- 4-5 1/ha za Sorghum halepense, Cirsium arvense, Rumex crispus, Rumex

obtusifolius,Artemisia vulgaris, Taraxacum officinale, Aegopodium podagraria

- 6-8 1/ha za Rubus spp., Cyperus rotundus

- 8-10 1/ha za Cynodon dactylon

Primjenjuju se pred cvatnju i u doba cvatnje korova kada je silazno kolanje asimilata najintenzivnije.

Primjena uz utrošak vode na bazi 100-200 1/ha:

Prije pripreme za sjetvu kukuruza, suncokreta, krumpira i šećerne repe, za suzbijanje:

- jednogodišnjih travnih i širokolisnih korova kada su 5-10 cm visoki u dozi 1,5-2 1/ha, pirike - kada je visine 10-25 $\mathrm{cm}$ u dozi 2-3 1/ha

- Cirsium arvense u stadiju razvoja pune rozete (15-25 cm visine) u dozi 3-4 1/ha.

Obrada tla i sjetva mogu se obaviti 5 dana nakon primjene.

Nije dopuštena uporaba glifosata prije sjetve šećerne repe na laganim pjeskovitim tlima.

Nakon žetve/berbe kultura (strništa, površine iza povrtnih kultura...), za suzbijanje:

- pirike-kada je visine 10-25 cm u dozi 2-3 1/ha, Cirsium arvense u stadiju razvoja pune rozete (15-25 cm visine) u dozi 3-5 1/ha, divljeg sirka kada je visine $15-30 \mathrm{~cm}$ i poljskog slaka (Convolvulus arvensis) kada je visok 20-40 cm u dozi 5-6 1/ha. 
U vinogradima, voćnjacima (visokih uzgojnih oblika): jabuke, kruške, marelice, masline, za suzbijanje:

- jednogodišnjih travnih i širokolisnih korova kada su 5-10 cm visoki u dozi 1,5-2 1/ha:

- pirike-kada je visine 10-25 $\mathrm{cm}$ u dozi 2-3 1/ha, Cirsium arvense u stadiju razvoja pune rozete (15-25 cm visine) u dozi 3-4 1/ha, divljeg sirka kada je visine $15-30 \mathrm{~cm}$ i poljskog slaka (Convolvulus arvensis) kada je visok 20-40 cm u dozi 5-6 1/ha, troskota (Cynodon dactylon) kada je visine 10-25 cm razdvojenom (split) pri-mjenom 2 x 2,5 l/ha.

Ne smije se koristiti u mladom voćnjaku i vinogradu (do 2 godine) dok je kora zelena, odnosno sve dok još nije formirana prava kora voćaka i vinove loze. Primjenom pripravaka na bazi glifosata sa smanjenim količinama vode može se uštedjeti, a za to je potrebna ispravna prskalica, sapnice kojima se može precizno primijeniti 100-200 1 vode po hektaru, podešen radni tlak i prilagođena brzina traktora.

Za tretiranje manjih površina (okućnice, oko gospodarskih objekata, kanala, rubova cesta, ograda, oko dalekovoda, groblja i dr.) leđnim prskalicama za suzbijanje jednogodišnjih korova rabi se 1\% koncentracija; za suzbijanje višegodišnjih korova $2 \%$ (100 odnosno $200 \mathrm{ml}$ pripravka u 101 vode).

\subsection{Fosfinska kiselina(aminofosfonati)}

(engl. Phosphinic acid)

Herbicidi iz grupe fosfinske kiseline kod osjetljivih biljaka inhibiraju aktivnost enzima glutamin sintetaze, odgovornog za sintezu glutamina iz glutamata, čija inhibicija izaziva nagomilavanje organskog amonijaka u biljnim stanicama koji na kraju postaje koban za biljku, zbog čega su razvrstani u HRAC grupu H.

Jedini predstavnik ove grupe je kontaktni neselektivni herbicid glufosinat-amonij koji je namijenjen suzbijanju svih zeljastih biljnih vrsta. Međutim, glufosinat-amonij suzbija samo nadzemne zeljaste biljne organe pa višegodišnje vrste korova i nakon što ih uništimo, iz podzemnih organa ponovno potjeraju. Rabi se kao kontaktni totalni herbicid za suzbijanje jedno i višegodišnjih korova u voćnjacima i vinogradima te na nepoljoprivrednim površinama, kao i za desikaciju suncokreta, uljane repice, soje i krumpira. Biljka ga usvaja listom. Ekološki je prihvatljiv. Genetičkim modifikacijama uzgojene su sorte soje, pamuka i hibridi kukuruza rezistetni na učinak ovog herbicida.

\subsubsection{Glufosinat}

Glufosinat-amonij je totalni herbicid širokog spektra. Sličan je glifosatu po tome što ima jedno mjesto djelovanja, a to je enzim glutamin sintetaza odgovoran za sintezu glutamina iz glutamata.

Učinkovit na sve (zelene) stadije razvoja korova. Najbolji učinak kada korov ima veliki broj dobro razvijenih listova. Rabi se i za suzbijanje korova u kanalima za navodnjavanje i odvodnjavanje. Pogodan za primjenu na nasipima, terasama, uz ceste i željezničke pruge jer ne razara korijenov sustav korova i nema opasnosti od erozije. 
Prskanje obaviti samo na suhim korovima. Pripravak remeti metabolizam u stanici.

$\mathrm{LD}_{50}$ 1450. S.O. = III.

\subsection{Dinitroanilini}

(engl. Dinitroaniline)

Herbicidi iz grupe dinitroanilina se kod osjetljivih biljaka vežu za tubulin, glavni mikrotubularni protein, gdje formiraju herbicid-tubulin kompleks koji inhibira obrazovanje mikrotubulina, usljed čega dolazi do onemogućavanja odvajanja kromatida kromosoma u toku mitoze, a time i spriječavanja diobe stanica, zbog čega su razvrstani u HRAC grupu K1.

Dinitroanilini predstavljaju relativno stariju, ali vrlo značajnu skupinu zemljišnih herbicida. Biljka ih apsorbira korijenom i koleoptilom u vodi. Trenutno se iz ove grupe na tržištu jedino može naći veći broj pripravaka na osnovi pendimetalina. Ovaj herbicid suzbija jednogodišnje uskolisne i neke širokolisne korove. Selektivan je za veliki broj različitih kultura kao npr: krumpir, kukuruz, žitarice, duhan, suncokret, grah, grašak, soju, jagodu, papriku, rajčicu, luk i dr. Pendimetalin se koristi poslije sjetve ili sadnje, a prije nicanja kulture. Najznačajnije mjesto apsorpcije kod visoko osetljivih travnih korova je koleoptil. Translokacija nije od značaja za suzbijanje klijanaca korova, jer se apsorpcija odigrava u koleoptilu i korijenu gdje se i događa herbicidna aktivnost. Relativno je perzistentan te je kod primjene u povrtnicama potrebno voditi računa o plodoredu.

\subsubsection{Pendimetalin}

Djelatna tvar zaustavlja diobu stanica snažnim djelovanjem mikrotubule što u konačnici izaziva zaustavljanje rasta korijena širokolisnih korova ili čvora busanja travnih korova.

Sve djelatne tvari ove grupe su sjajno žute boje zahvaljujući nitro (- NO2) grupama na fenilnom prstenu te ih često nazivaju i “žutim” spojevima. Cijela grupa je otkrivena i razvijena zahvaljujući radu na razvoju sinteze boja. Lipofilni su gotovo netopljivi u vodi te predstavljaju neznatnu opasnost od kontaminacije voda. Brzo se razgrađuju na suncu. Selektivni zemljišni pripravak za suzbijanje manjeg broja jednogodišnjih uskolisnih i širokolisnih korova u vrijeme njihovog nicanja ili ranog posta. Ne na tlima s manje od 1,5\% humusa. Zbog uskog spektra u kombinacijama s drugim djelatnim tvarima je selektivan u velikom broju kultura. Gotovo netopljiv u vodi. U proizvodnim programima u zaštiti: graška, graha i graha mahunara, kupusnjača iz prijesadnica i mrkve i peršina. Nakon primjene u krumpiru i povrću iste godine ne smiju se sijati: repa i cikla, a dopuštena je sjetva: kupusa, luka, salate, rajčice, mrkve, soje i kukuruza. Grašak, grahorica i ječam smiju se sijati 3 mjeseca nakon primjene pendimetalina na istoj površini. U slučaju propadanja usjeva dopuštena je sjetva samo kukuruza, a nakon 3 mjeseca svih ostalih kultura u kojima ova djelatna tvar ima dozvolu za uporabu.

LD $_{50}$ 1250. S.O. = III. K - 42 dana rajčica; 63 dana kukuruz za silažu, luk, krumpir, paprika i kupus; OVP ostalo. 


\subsection{Benzamidi}

(engl. Benzamide)

Benzamidi imaju isti mehanizam djelovanja kao i herbicidi iz grupe dinitroanilina, odnosno i oni se kod osjetljivih biljaka vežu za tubulin, glavni mikrotubularni protein, gdje formiraju herbicid-tubulin kompleks koji inhibira obrazovanje mikrotubulina, usljed čega dolazi do onemogućavanja odvajanja kromatida kromosoma u toku mitoze, a time i spriječavanja diobe stanica, zbog čega su benzamidi razvrstani u HRAC grupu K1.

Jedini predstavnik ove grupe je propizamid koji se apsorbira korijenom i prenosi u nadzemne dijelove biljke provodnim sustavima ksilema. Aktivan je kada se primjeni preko zemljišta, a folijarnu aktivnost pokazuje samo na nekim korovnim vrstama. Kada se apsorbira listom translokacija je svedena na najmanju moguću mjeru. Izaziva zaustavljanje rasta korijena širokolisnih ili čvora busanja travnih korova.

\subsubsection{Propizamid}

Djelatna tvar izaziva zaustavljanje rasta korijena širokolisnih ili čvora busanja travnih korova. Učinkovit u suzbijanju viline kose - Cuscuta spp. Zemljišni herbicid za čiju učinkovitost je neophodan veći sadržaj vlage u tlu i niže temperature. Visoko selektivan za lucernu, neovisno o njenoj starosti i tipu tla. Neučinkovit na korove iz fam.: Compositae, Cruciferae, Leguminosae i Liliaceae. Usvaja se većinom preko korijena. Inhibira diobu stanica.

$$
\mathrm{LD}_{50} \text { 8300. S.O. }=\text { III. }
$$

\subsection{Kloracetamidi}

(engl. Chloroacetamide)

Kloracetamidi kod osjetljivih biljaka inhibiraju obrazovanje mikrotubulina, usljed čega dolazi do onemogućavanja odvajanja kromatida kromosoma u toku mitoze, a time i spriječavanja diobe stanica, zbog čega su razvrstani u HRAC grupu K3.

Kloracetamidi su nešto starija, ali vrlo značajna skupina herbicida sa širokim područjem primjene za suzbijanje jednogodišnjih travnih korova. Herbicide iz ove skupine primjenjujemo nakon sjetve, a prije nicanja. Biljka ih usvaja preko korijena u vodi i preko hipokotila. Do danas nije u potpunosti razjašnjen mehanizam njihovog djelovanja, ali se zna da utječu na biosintezu masnih kiselina i staničnu membranu, zbog čega priječe razvoj klijanca pa se kod osjetljivih biljaka razvija abnormalna stabljika koja ne može isklijati. Neki od herbicida iz ove grupe su učinkoviti ako ih primijenimo sve do faze dva lista korovnih trava.

Herbicidi iz ove grupe imaju široko područje primjene. Tako se acetoklor, S-metolaklor i propizaklor koriste za suzbijajanje jednogodišnjih travnih i nekih širokolisnih korova u kukuruzu, soji, suncokretu, šećernoj repi i duhanu, dok su dimetaklor i metazaklor koriste u uljanoj repici i kupusnjačama. U tlu se u aktivnom obliku zadrže nekoliko tjedana pa do tri mjeseca. Odlično suzbijaju jednogodišnje travne i neke širokolisne korove. Herbicidi iz ove grupe izazivaju zaustavljanje rasta korijena kod širokolisnih korova ili čvora busanja kod travnih korova. Radi 
proširenja spektra i na širokolisne korove, redovito se rabe u kombinaciji s drugim na ovu skupinu korova učinkovitim herbicidima.

\subsubsection{Dimetaklor}

Djelatna tvar izaziva zaustavljanje rasta čvora busanja trava. Pripravak namijenjen suzbijanju važnijih korova u usjevu uljane repice: slakoperka, koštan, ljuljevi, mišji repak, a od širokolisnih: kamilica, mrtva kopriva, mišjakinja, jarmna, čestoslavica... Sjeme mora biti prekriveno slojem zemlje barem $2 \mathrm{~cm}$. Najbolje djelovanje na korove se postiže kada su u nicanju ili prvom paru pravih listova.

\section{LD $_{50} 1600, \mathrm{~K}-\mathrm{OVP}$.}

\subsubsection{S-dimetenamid (dimetanamid-P)}

S-dimetenamid se rabi za suzbijanje travnih i pojedinih širokolisnih korova.

Primjenjuje se nakon sjetve, ali i neposredno nakon nicanja usjeva i korova. Najčešće se rabi u kombinaciji s drugim djelatnim tvarima. Vrlo dobri rezultati dobiveni i inkorporacijom dimetenamida odmah nakon prskanja.

LD $_{50}$ 2007. S.O. = III. K - OVP. (Frontier); 100 dana za ozimu uljanu repicu (Tanaris).

\subsubsection{Metazaklor}

Metazaklor je zemljišni herbicid djelotvoran na širokolisne i neke uskolisne korove. Primjenjuje se nakon sjetve, a prije nicanja repice i korova. Izaziva zaustavljanje rasta čvora busanja trava. Moguće ga je primijeniti i u vegetaciji, ali vrlo rano i po mogućnosti pred kišu koja će djelatnu tvar spustiti u zonu klijanja korova. Visoko selektivan za usjev (dobro pripremiti tlo tako da sjeme uljane repice bude prekriveno slojem zemlje).

$$
\mathrm{LD}_{50} \text { 2150, S.O. = III. }
$$

\subsubsection{S-metolaklor}

S-metolaklor je zemljišni herbicid za suzbijanje jednogodišnjih sjemenskih uskolisnih i pojedinih širokolisnih korova. Najčešće se rabi poslije sjetve, a prije nicanja uzgajane biljke i u kombinacijama s drugim djelatnim tvarima. Izaziva zaustavljanje rasta čvora busanja trava. Na lakšim i humusom siromašnijim tlima rabe se niže doze.

$\mathrm{LD}_{50}$ 2780. S.O. = III.

\subsubsection{Petoksamid}

Petoksamid je selektivni herbicid namijenjen za suzbijanje jednogodišnjih sjemenskih uskolisnih i pojedinih širokolisnih korova u usjevu kukuruza. Za suzbijanje ukupnog spektra korova rabi se u kombinacijama s triazinskim pripravcima.

LD $_{50} 983$, K-OVP, kukuruz za silažu može se žeti najranije u fenofazi mliječne zriobe. 


\subsection{Acetamidi}

(engl. Acetamide)

Acetamidi imaju isti mehanizam djelovanja kao i herbicidi iz grupe kloracetamida i oksiacetamida, odnosno i oni se kod osjetljivih biljaka inhibiraju obrazovanja mikrotubulina, uslijed čega dolazi do onemogućavanja odvajanja kromatida kromosoma u toku mitoze, a time i spriječavanja diobe stanica, zbog čega su razvrstani u HRAC grupu K3.

Jedini predstavnik ove grupe je selektivni herbicid napropamid koji je perzistentan i koristi se za suzbijanje velikog broja širokolisnih i uskolisnih korova u većem broju kultura (pa je i mogućnost štete od rezidua veća), zbog čega poslije primjene napropamida treba voditi računa o odabiru naredne kulture u plodosmjeni. Napropamid se vrlo brzo apsorbira korijenom, zbog čega su biljke prema njemu osjetljive samo u fazi nicanja. Primarno izaziva zaustavljanje rasta korijena kod širokolisnih ili čvora busanja kod travnih korova.

\subsubsection{Napropamid}

Napropamid je selektivni zemljišni herbicid koji se koristi za suzbijanje velikog broja širokolisnih i uskolisnih korova u nicanju u većem broju kultura. U usjevu kupusnjača se rabi samo kod uzgoja iz prijesadnica, a kod rajčice i paprike iz sjemena i prijesadnica. Rabi se i u voćnjacima i vinogradima starijim od godinu dana ( jabuka, kruška, breskva, nektarina, marelica, šljiva, trešnja, višnja, agrumi i drugi nasadi). Djelatna tvar izaziva zaustavljanje rasta korijena kod širokolisnih ili čvora busanja kod travnih korova. Folijarna apsorpcija mu je slaba. Na suncu se $50 \%$ djelatne tvari razgradi za 4 dana te ga je potrebno inkorporirati u tlo prije sjetve ili sadnje. Veliki sadržaj organske tvari u tlu značajno smanjuje učinkovitost. Perzistentan je i primjenjiv u većem broju kultura (pa je i mogućnost štete od rezidua veća), zbog čega treba voditi računa o odabiru naredne kulture u plodosmjeni. Na proljeće prve godine nakon primjene na tretiranoj površini smiju se uzgajati: suncokret, grah, grašak, paprika, duhan, rajčica, krumpir i kupusnjače. Godinu dana nakon primjene na istoj površini dopušteno je sijati: strne žitarice (osim zobi), kukuruz, sirak, šećernu i stočnu repu i salatu. Sjetva zobi dopuštena je tek nakon 16 mjeseci od primjene napopamida.

$$
\mathrm{LD}_{50} 4640 \text {, S.O. }=\text { III. }
$$

\subsection{Oksiacetamidi}

\section{(engl. Oxyacetamide)}

Oksiacetamidi imaju isti mehanizam djelovanja kao i herbicidi iz grupe kloracetamida i acetamida, odnosno i oni se kod osjetljivih biljaka inhibiraju obrazovanje mikro-tubulina, uslijed čega dolazi do onemogućavanja odvajanja kromatida kromosoma u toku mitoze, a time i spriječavanja diobe stanica, zbog čega su razvrstani u HRAC grupu K3.

Jedini predstavnik ove grupe je selektivni herbicid flufenacet koji je namijenjen suzbijanju uskolisnih i nekoliko raširenih širokolisnih korova u usjevu krumpira, soje i kukuruza. Koristi se poslije sjetve, a prije nicanja usjeva i (ili) u ranom post-em. 
Vrlo je povoljnih ekoloških i toksikoloških osobina. Primarno izaziva zaustavljanje rasta korijena kod širokolisnih ili čvora busanja kod travnih korova.

\subsubsection{Flufenacet}

Djelatna tvar izaziva zaustavljanje rasta čvora busanja kod travnih i rasta korijena kod širokolisnih korova. Djeluje kao inhibitor dijeljenja stanica. Vrlo je povoljnih ekoloških i toksikoloških osobina, a i koristi se u nižim dozama u odnosu na standarde. Djelotvoran u suzbijanju uskolisnih i nekoliko raširenih širokolisnih korova u pre i (ili) ranom post-em.

Posebno učinkovit na Sorghum halepense iz sjemena.

$\mathrm{Na}$ tržištu se nalazi uglavnom u kombinaciji s drugim djelatnim tvarima radi proširenja spektra i za suzbijanje širokolisnih korova.

LD $_{50} 589$ - 1617. S.O. = III. K - OVP.

Pripravak: Plateen WG 41,5

\subsection{Tiokarbamati}

(engl. Thiocarbamate)

Herbicidi iz grupe tiokarbamata kod osjetljivih biljaka inhibiraju sintezu lipida neophodnih za izgradnju stanične membrane, pri čemu ne inhibiraju enzim acetilkoenzim A karboksilazu (ACCase), usljed čega dolazi do narušavanja sklada u razvoju i normalnim funkcijama unutar biljke, zbog čega su tiokarbamati razvrstani u HRAC grupu N.

Jedini predstavnik ove skupine je prosulfokarb - selektivni herbicid za suzbijanje jednogodišnjih širokolisnih i nekih uskolisnih korova u usjevu pšenice. Biljka ga apsorbira putem lista i korijena zbog čega se primjenjuje neposredno nakon sjetve ili najkasnije do stadija 3 lista pšenice. U osjetljivim biljkama prosulfokarb se nakuplja u meristemu usljed čega dolazi do inhibicije njihovog porasta.

\subsubsection{Prosulfokarb}

Suzbija jednogodišnje širokolisne i neke travne korove. Primjenjuje se neposredno nakon sjetve ili najkasnije do stadija 3 lista pšenice. Biljka ga apsorbira putem korijena. Nakuplja se u meristemu i zaustavlja rast. Kod pliće položenog sjemena pšenice može prolazno zaustaviti razvoj pšenice.

LD $_{50}$ 1960. O - III. T - 0,1 pšenica.

\subsection{Benzofuran}

(engl. Benzofuran)

Benzofurani imaju isti mehanizam djelovanja kao i herbicidi iz grupe karbamata, odnosno i oni kod osjetljivih biljaka inhibiraju sintezu lipida neophodnih za izgradnju stanične membrane, pri čemu ne inhibiraju enzim acetilkoenzim A karboksilazu (ACCase), usljed čega dolazi do narušavanja sklada u razvoju i normalnim funkcijama unutar biljke, zbog čega su i oni razvrstani u HRAC grupu N. 
Jedini predstavnik ove skupine je etofumesat - zemljišni kontaktni i rezidualni herbicid za suzbijanje jednogodišnjih uskolisnih i širokolisnih korova u usjevu šećerne i stočne repe. U biljku ulazi preko korijena, koleoptile, hipokotila i preko lista odakle se translocira u sve nadzemne organe. Perzistentnost ovisi o primijenjenoj dozi (6 do 10 mjeseci). Rabi se sam ili u kombinaciji sa fenmedifamom i desmedifamom.

\subsubsection{Etofumesat}

Etofumesat je zemljišni kontaktni i rezidualni herbicid namijenjen za suzbijanje jednogodišnjih uskolisnih i širokolisnih korova u usjevu šećerne i stočne repe. Primarno se usvaja korijenom kod širokolisnih i koleoptilom kod uskolisnih korova. Rabi se sam ili u kombinaciji s drugim djelatnim tvarima. Fitotoksične pojave mogu nastati kod visokih doza primjene i pri temperaturama višim od $20 \mathrm{oC}$, zbog čega ga ne treba koristiti na tlima s više od $5 \%$ humusa kao i pri jakom suncu. Na lakšim tlima rabi se u nižim dozama. Na tretiranim površinama može se sijati samo šećerna repa. Ako se rabi u maksimalnim dozama pšenica se ne smije sijati ni iduće godine zbog perzistentnosti.

$\mathrm{LD}_{50}$ 1200. S.O. = III.

\subsection{Derivati fenoksi-karboksilnih kiselina}

(engl. Phenoxy-carboxylic-acid)

Herbicidi iz grupe derivata fenoksi-karboksilnih kiselina kod osjetljivih biljaka djeluju kao indol octena kiselina, odnosno slično biljnim hormonima auksinima (,sintetički auksini”), usljed čega dolazi do stimulacije i nenormalne diobe stanica, što za posljedicu kod osjetljive biljke kao i njenih organa pokazuje simptome slične simptomima koje izazivaju auksini, a oni uključuju pojavu enacija, uvijanja stabla i peteljki, izduživanje i kovrčanje lišća te pojavu drugih deformacija, poslije čega se pojavljuje kloroza u točkama rasta, inhibicija rasta, uvenuće i nekroza, što sve zajedno na kraju dovodi do ugibanja osjetljive biljke. Na osnovu navedenog mehanizma djelovanja derivati fenoksi-karboksilnih kiselina su razvrstani u HRAC grupu 0.

Derivati fenoksi-karboksilnih kiselina su stara, jeftina i još uvijek vrlo značajna skupina herbicida koja se odlikuje dobrom efikasnošću za suzbijanje jednogodišnjih i višegodišnjih širokolisnih korova. Još ih nazivamo i hormonskim herbicidima jer im je djelovanje u biljci slično biljnim hormonima auksinima. Primarno djelovanje ovih herbicida se pokazuje u vidu promjene propustljivosti staničnih membrana i promjenama u metabolizmu nukleinskih kiselina. Isto tako, ovi herbicidi zakiseljavaju staničnu membranu i stimuliraju aktivnost u membranama vezane ATP-aze. Redukcijom u apoplazmi snižena $\mathrm{pH}$ inducira elongaciju stanica izazvanu povećanjem aktivnosti nekih enzima odgovornih za funkcioniranje staničnih membrana. Niske koncentracije ovih herbicida također stimuliraju aktivnost RNK polimeraze uslijed čega dolazi do povećane biosinteze RNK, DNK i proteina. Abnormalno povećanje ovih procesa dovodi do nekontrolirane diobe stanica i rasta, kao i destrukcije staničnih tkiva. Nasuprot tome, visoke koncentracije ovih herbicida inhibiraju diobu stanica i rast, pri čemu se obično u meristemskim djelovima biljke akumuliraju fotosintetski asimilati i herbicidi iz floema. Također, herbicidi iz 
ove grupe stimuliraju izlučivanje etilena što u mnogim slučajevima dovodi do pojave karakterističnih simptoma tipa epinastija. Osjetljive biljke obično ugibaju za 3-5 tjedana.

Derivate fenoksikarboksilnih kiselinabiljka prvenstveno usvaja preko lista, ali i preko korijena. Oni su izraziti sistemici te se sokovima premještaju u sve dijelove biljke. Djelotvorni su samo na jednogodišnje i višegodišnje širokolisne korove.

Glavno područje primjene su im strne žitarice, kukuruz te livade i pašnjaci. U tlu nisu perzistentni pa se unutar nekoliko tjedana do 3 mjeseca potpuno razgrade. Mogu izazivati velike ekonomske štete ako se primijene prije ili poslije propisanog roka na strnim žitaricama i kukuruzu, kao i zanošenjem škropiva na druge osjetljive širokolisne kulture (suncokret, šećerna repa, voćnjaci i vinogradi). Na osnovi herbicida iz ove skupine registriran je veći broj pripravaka, kao i veći broj različitih kombinacija pripravaka.

\subsubsection{2,4-D}

2,4-D je selektivni translokacijski pripravak za suzbijanje nekih jednogodišnjih i višegodišnjih širokolisnih korova u usjevima žitarica, kukuruza, livadama i pašnjacima. Kao esteri manje su topljivi, ali i postojaniji u okolišu. Razgradnja se odvija mikrobiološkim putem.

Ne koristiti u usjevu pšenice i ječma nakon busanja, jer se javljaju deformacije na klasu i klasićima. Velika je opasnost za susjedne kulture zbog zanošenja vjetrom. Ne ide u usjeve zobi i pšenoraži. Poseban oprez kada je u formi estera!

$\mathrm{LD}_{50}$ 300-666. S.O. = III.

\subsubsection{Diklorprop-P $=2,4$ DP-P}

Djelatna tvar izaziva poremećaj ravnoteže hormona odgovornih za izduživanje i dijeljene stanice, sintezu bjelančevina i disanje. Folijarni translokacijski pripravak za suzbijanje nekih širokolisnih korova od početka busanja do početka vlatanja u žitaricama. Rabiti kada su temperature više od 5o C. Većinom u kombinaciji s drugim djelatnim tvarima.

$\mathrm{LD}_{50}$ 800. S.O. = III. K - OVP za žitarice.

\subsubsection{MCPA}

Djelatna tvar izaziva poremećaj ravnoteže hormona odgovornih za izduživanje i dijeljene stanice, sintezu bjelanjčevina i disanje. Selektivni translokacijski pripravak za suzbijanja nekih širokolisnih korova u žitaricama, livadama i pašnjacima. Primjenjuje se tijekom busanja.

LD $_{50}$ 700-800. S.O. = III. K - strne žitarice OVP.

\section{Pripravak: Optica trio.}

\subsubsection{Mekoprop-P}

Herbicid za post-em tretman širokolisnih korova u travnim kulturama.

$\mathrm{LD}_{50}$ 431. S.O. = III. K - strne žitarice OVP.

\section{Pripravak: Optica trio.}




\subsection{Derivati benzojeve kiseline}

(engl. Benzoic acid)

Derivati benzojeve kiseline imaju isti mehanizam djelovanja kao i herbicidi iz grupe derivata fenoksi-karbonskih kiselina i derivata piridin karboksilne kiseline, odnosno i oni kod osjetljivih biljaka djeluju kao indol octena kiselina, tj. slično biljnim hormonima auksinima ("sintetički auksini”), uslijed čega dolazi do stimulacije i nenormalne diobe stanica, što za posljedicu kod osjetljive biljke pokazuje simptome slične simptomima koje izazivaju auksini, što sve zajedno na kraju dovodi do ugibanja osjetljive biljke. Na osnovu navedenog mehanizma djelovanja derivati benzojeve kiseline su razvrstani u HRAC grupu $O$.

Jedini predstavnik ove skupine je dikamba - selektivni sistemični translokacijski herbicid namijenjen za suzbijanje širokolisnih korova u usjevu kukuruza i strnih žitarica, kao i na livadama, pašnjacima i strništima. Dikamba se apsorbira lišćem, korijenom i stabljikom biljaka, odakle se transportira i ksilemom i floemom te akumulira u dijelovima biljke koji rastu, zbog čega se primjenjuje nakon nicanja korova. Translokacija je sporija kod trava nego kod drugih tolerantnih biljnih vrsta. Razlika u brzini transporta povezana je sa razlikama u osjetljivosti pojedinih biljnih vrsta. Na tržištu se nalazi veći broj pripravaka na bazi ove djelatne tvari, ali i u kombinaciji s drugim djelatnim tvarima radi proširenja spektra njenog djelovanja.

\subsubsection{Dikamba}

Dikamba je selektivni translokacijski herbicid namijenjen za suzbijanje jednogodišnjih i nekih višegodišnjih širokolisnih korova u usjevu žitarica, kukuruza (od 3-5 listova) i na strništima. Širokog je spektra djelovanja. Posebno učinkovit na slak. Preko lista se premješta u sve dijelove biljke. Većinom je prisutan u složenim pripravcima. Na korovima izaziva pojavu deformacija pojedinih dijelova ili cijele biljke (uvijanja), pri čemu nakon desetak dana dolazi do odumiranja osjetljive biljke.

$\mathrm{LD}_{50}$ 1040-2900. S.O. $=$ III.

\subsection{Derivati piridin karboksilne kiseline}

(engl. Pyridine carboxylic acid)

Derivati piridin karboksilne kiseline imaju isti mehanizam djelovanja kao i herbicidi iz grupe derivata fenoksikarbonskih kiselina i derivata benzojeve kiseline, odnosno i oni kod osjetljivih biljaka djeluju kao indol octena kiselina, tj. slično biljnim hormonima auksinima (,sintetički auksini”), uslijed čega dolazi do stimulacije i nenormalne diobe stanica, što za posljedicu kod osjetljive biljke pokazuje simptome slične simptomima koje izazivaju auksini, što sve zajedno na kraju dovodi do ugibanja osjetljive biljke.

$\mathrm{Na}$ osnovu navedenog mehanizma djelovanja derivati piridin karboksilne kiseline su razvrstani u HRAC grupu $O$.

Derivati piridin karboksilne kiseline su relativno starija skupina sistemičnih translokacijskih herbicida namijenjenih za suzbijanje širokolisnih korova u usjevu strnih žitarica i kukuruza, kao i na livadama i pašnjacima, ali i kao herbicidi za suzbijanje drvenastih korova (naročito pikloram). 
Primjenjujemo ih nakon nicanja korova (preko lista). Fluroksipir se primjenjuje kao esterfluroksipir metil koji se odmah poslije folijarne apsorpcije hidrolizira do izvorne kiseline (fluroksipira) koja tek tada pokazuje herbicidnu aktivnost izazivajući karakteristične simptome kao herbicidi auksinskog tipa. Perzistentnost u tlu većine herbicida iz ove skupine je relativno kratka, dok je pikloram vrlo perzistentan. Ispiru se u dublje slojeve te mogu zagaditi podzemne vode. Klopiralid je relativno perzistentan u biljci. Na tržištu se nalazi veći broj pripravaka na bazi ovih djelatnih tvari, ali i u kombinaciji s drugim djelatnim tvarima radi proširenja spektra njihovog djelovanja.

\subsubsection{Fluroksipir}

Pripravci na bazi fluroksipira namijenjeni su za suzbijanje većeg broja širokolisnih korova u usjevu strnih žitarica (Galium aparine) i kukuruza (Abutilon theophrasti), voćnjacima (Convolvulus sp., Rubus sp., ...), usjevu luka te pašnjacima i livadama (Lamium sp., Taraxacum officinale). Fluroksipir se sat vremena nakon prskanja u cijelosti apsorbira u biljci, poslije čega nema opasnosti od ispiranja. K-63 žitarice, kukuruz i jezg. voće; 21 livade i pašnjaci za ispašu i košnju. Slamu ne koristiti za kompost namijenjen povrću.

$\mathrm{LD}_{50}$ 2405. S.O. = III.

\subsubsection{Klopiralid}

Pripravci na bazi klopiralida su namijenjeni suzbijanju širokolisnih korova u usjevima kukuruza, strnih žita, šećerne repe, uljane repice i luka. Najčešće se rabi samostalno ili u kombinaciji s drugim pripravcima (šećerna repa, kukuruz) ili drugim djelatnim tvarima (pšenica). Najbolji učinak u suzbijanju korova postiže se kada su korovi u fazi od 2-6 listova. Kukuruz u vrijeme prskanja treba biti u fazi 2-5 listova, a pšenica i ječam od sredine busanja do konca vlatanja. U šećernoj repi se primjenjuje od kotiledona do pred sklapanje redova (2-3 x). U uljanoj repici se primjenjuje od 2 prava lista do pojave rozete. U programu Herbosa se koristi za zaštitu kupusnjača (iz sjemena od 2-6 listova i prijesadnica u rozeti) i luka (iz sjemena 3-4 lista i lučica 2-4 lista). U plodosmjeni ne sijati: lucernu, salatu, grašak (16 mjeseci) i mrkvu zbog izvanredno visoke osjetljivosti na ostatke u tlu. Ne rabiti slamu za proizvodnju komposta za povrtnice. Nakon primjene 2-3 tjedna ne ulaziti u okopavanja ili kultivacije.

$$
\mathrm{LD}_{50} \text { 4300. S.O. = III. }
$$

\subsubsection{Pikloram}

Djelatna tvar izaziva poremećaj ravnoteže hormona odgovornih za izduživanje i dijeljenje stanice, sintezu bjelančevina i disanje. Pripravak za suzbijanje poludrvenastih i drvenastih te jednogodišnjih i višegodišnjih širokolisnih korova. Vrlo brzo se usvaja (listom i korijenom), translocira i akumulira u meristemskim tkivima. Opasnost od zanošenja! Učinkovit u suzbijanju više od 200 vrsta. Primijeniti u vrijeme najintenzivnijeg razvoja drvenastih korovnih vrsta. Do sušenja drvenastih biljaka dolazi za 3 mjeseca.

$$
\mathrm{LD}_{50} \text { 8200. S.O. = III. }
$$


Trava s prskanih površina ne smije se koristiti za ishranu mliječnih životinja. Ispaša zabranjena 42 dana. $U$ tlu postojan te se u slijedećih 18 mjeseci od primjene ne smije uzgajati ni jedna kultura.

\subsection{Različitog kemijskog podrijetla}

\subsubsection{Aminopiralid}

Aminopiralid je novi herbicid koji se koristi za suzbijanje širokolisnih korova (kamilica, broćika, mišjakinja, samonikli suncokret, slak, osjak i dr.) u usjevu jare i ozime pšenice te jarog i ozimog ječma.

$\mathrm{LD}_{50}>$ 5000. S.O. = izvan skupine otrova.

Pripravak: Lancelot 450 WG.

\subsubsection{Flurokloridon}

Flurokloridon je kontaktni zemljišni herbicid namijenjen suzbijanju jednogodišnjih širokolisnih i nekih uskolisnih korova u usjevima kukuruza, suncokreta i krumpira. Dobre je selektivnosti i dugotrajnog djelovanja. Djelatna tvar izaziva inhibiciju enzima fiton desaturaze (PDS) odgovornog za sintezu karotenoida. Bez karotenoida, koja ima zaštitnu ulogu, molekula klorofila se vrlo brzo razgradi te su novi listovi svijetlo žute ili bijele boje. Primjenjuje se kao pre-em. herbicid u kombinaciji s drugim djelatnim tvarima radi većeg djelovanja na prisutnu korovnu floru. Dozu prilagoditi sadržaju humusa. Ne treba ga koristiti na tlima s manje od 1,5\% humusa. Optimalno vrijeme primjene: prije nicanja. Nakon uporabe izbjegavati sjetvu uljane repice na tretiranoj površini.

LD $_{50}$ 1980. S.O. = III. K - 63 krumpir i silažni kukuruz, suncokret i kukuruz za zrno OVP.

\section{FUNGICIDI}

\section{A) ORGANSKI FUNGICIDI}

\subsection{Acilalanini}

(engl. Acylalanines)

Fungicidi iz ove grupe inhibiraju aktivnost enzima RNK polimeraze I što dovodi do zaustavljanja sinteze nukleinskih kiselina kod fitopatogenih gljiva, na temelju čega su razvrstani u FRAC grupu A1. Sistemični su fungicidi s protektivnim i kurativnim djelovanjem. Apsorbiraju se putem lišća, stabljike (stabla) i korijena. Koriste se za suzbijanje velikog broja patogena iz razreda Oomycota. Imaju visok rizik za razvoj rezistentnosti, zbog čega se formuliraju i koriste u kombinaciji s protektivnim fungicidima. 


\subsubsection{Benalaksil}

Fungicid za suzbijanje uzročnika plamenjače vinove loze, krumpira, rajčice, luka i krastavaca (samo u polju).

$\mathrm{LD}_{50}$ - 4200. S.O. - III.

\subsubsection{Metalaksil-M}

Sve kombinacije koriste se za suzbijanje uzročnika plamenjače vinove loze. Kombinacija s bakrom koristi se za suzbijanje uzročnika plamenjače hmelja, soje, duhana, krumpira, rajčice, kupusa, krastavca i luka, a kombinacija s mankozebom protiv uzročnika plamenjače duhana, soje, šećerne repe, krumpira i rajčice.

$\mathrm{LD}_{50}$ 1438. S.O. - III.

\subsection{2.a) Za tretiranje sjemena}

Koristi se za zaštitu sjemena kukuruza od uzročnika fuzarioza, polijeganja nasada i drugih bolesti. Lako se i ravnomjerno nanosi na sjeme.

K - OVP.

\subsection{Hidroksi-2-amino-pirimidini}

(engl. Hydroxy-(2-amino-) pyrimidines)

Fungicidi iz ove grupe inhibiraju aktivnost enzima adenozin-deaminaze što dovodi do zaustavljanja sinteze nukleinskih kiselina kod osjetljivih fitopatogenih gljiva, na temelju čega su razvrstani u FRAC grupu A2. Sistemični su fungicidi s protektivnim i kurativnim djelovanjem. Apsorbiraju se lišćem, a u biljci se transportiraju ksilemom i imaju translaminarno djelovanje. Imaju srednji rizik za razvoj rezistentnosti.

\subsubsection{Bupirimat}

Bupirimat je djelatna tvar prikladna za korištenje u integriranim programima zaštite bilja. Koristi se preventinvno i kurativno za suzbijanje uzročnika pepelnice.

$\mathrm{LD}_{50}$ - 4000. S.O. - III.

\subsection{Benzimidazoli}

(eng. Benzimidazoles)

Djeluju na veliki broj gljiva. Fungicidi iz ove skupine akropetalni su sistemici sa bazipetalnim kretanjem samo kod zeljastih biljaka. Kod nekih gljiva utvrđena je pojava rezistentnosti.

\subsubsection{Tiofanat-metil}

Sistemični fungicid namijenjen za suzbijanje uzročnika bolesti pšenice i ječma: Blumeria (Erysiphe) graminis, Fusarium spp., Pseudocercosporella spp., Puccinia spp., Rhynchosporium secalis, Septoria tritici i Pyrenophora teres, kao i uzročnika bolesti šećerne repe: Cercospora beticola.

$$
\mathrm{LD}_{50} \text { - 6640-7500. S.O. - III. }
$$




\subsubsection{Tiabendazol}

Koristi se za tretiranje plodova agruma protiv uzročnika plijesni. Za prodaju potrebno je navesti upozorenje: "Kora agruma nije za jelo. Tretirano tiabendazolom."

$\mathrm{LD}_{50}-3100$, S.O. - III, K- OVP.

\subsection{Toluamidi}

(engl. Toluamides)

Fungicidi iz ove grupe inhibiraju obrazovanje $\beta$-tubulina u toku mitoze i na toj osnovi zaustavljaju normalnu diobu stanica kod fitopatogenih gljiva, na temelju čega su razvrstani u FRAC grupu B3. Kontaktni su fungicidi s preventivnim djelovanjem. Imaju mali do srednji rizik za razvoj rezistentnosti.

\subsubsection{Zoksamid}

Zoksamid je kontaktni fungicid namijenjen za preventivnu zaštitu od uzročnika plamenjače rajčice i vinove loze, kao i koncentrične pjegavosti rajčice.

$\mathrm{LD}_{50}>$ 5000. S.O. - III.

\subsection{Fenilurea}

(engl. Phenylureas)

Fungicidi iz ove grupe zaustavljaju normalnu diobu stanica kod fitopatogenih gljiva, na temelju čega su razvrstani u FRAC grupu B4. Kontaktni su fungicidi s preventivnim djelovanjem.

\subsubsection{Pencikuron}

Pencikuron je kontaktni fungicid namijenjen za zaštitu gomolja krumpira od Rhizoctonia solani.

$\mathrm{LD}_{50}>$ 5000. S.O. - III. K- OVP.

\subsection{Piridinilmetil-benzamidi}

(engl. Pyridinylmethyl-benzamides)

Fungicidi iz ove grupe utječu na delokalizaciju specifičnih proteina što dovodi do zaustavljanja mitoze i diobe stanica kod osjetljivih fitopatogenih gljiva, na temelju čega su razvrstani u FRAC grupu B5. Karakterizira ih preventivno djelovanje. Rezistentnost prema ovim fungicidima nije poznata.

\subsubsection{Fluopikolid}

Mezosistemični fungicid koji se na tržištu može pronaći u kombinacijama s drugim aktivnim tvarima. Suzbija uzročnike plamenjače u velikom broju kultura.

$\mathrm{LD}_{50}>5000$, S.O. - 


\subsection{Piridinil etilbenzamidi}

(engl. Pyridinyl ethylbenzamides)

Inhibiraju aktivnost enzima sukcinat dehidrogenaze. Jedini predstavnik ove skupine je fluopiram.

\subsubsection{Fluopiram}

Odlikuje ga novi mehanizam djelovanja protiv fitopatogene gljive Botrytis cinerea.

Kontaktno-sistemični fungicid s preventivnim djelovanjem. Najčešće dolazi u kombinacijama.

$\mathrm{LD}_{50}>$ 2000. S.O. - III.

\subsection{Oksatin karboksamidi}

(engl. Oxathiin carboxamides)

Fungicidi iz ove grupe inhibiraju aktivnost enzima sukcinat-dehidrogenaze čime ometaju protok elektrona u respiratornom lancu (kompleks II), što dovodi do zaustavljanja disanja kod osjetljivih fitopatogenih gljiva, na temelju čega su razvrstani u FRAC grupu C2. Sistemični su fungicidi. Koriste se za tretiranje sjemena. Imaju srednji rizik za razvoj rezistentnosti.

\subsubsection{Karboksin}

Sistemični fungicid za tretiranje sjemena žitarica protiv uzročnika prašne i smrdljive snijeti pšenice i ječma.

$\mathrm{LD}_{50}$ - 3820. S.O. - III. K - OVP.

\subsection{1.a) Za tretiranje sjemena}

\subsection{Piridin karboksamidi}

(engl. Pyridine carboxamides)

Piridin karboksamidi imaju isti mehanizam djelovanja kao i fungicidi iz grupe oksatin karboksamida, odnosno i oni inhibiraju aktivnost enzima sukcinat-dehidrogenaze čime ometaju normalni protok elektrona u respiratornom lancu (kompleks II), što dovodi do zaustavljanja disanja kod osjetljivih fitopatogenih gljiva, na temelju čega su i oni razvrstani u FRAC grupu C2. Sistemični su fungicidi. Imaju srednji rizik za razvoj rezistentnosti.

\subsubsection{Boskalid}

Odlikuje ga novi mehanizam djelovanja protiv fitopatogene gljive Botrytis cinerea.

Kontaktno-sistemični fungicid s preventivnim djelovanjem. Najčešće dolazi u kombinacijama.

$\mathrm{LD}_{50}>$ 5000. S.O. - izvan skupine otrova. 


\subsection{Metoksi-akrilati ("Strobilurini")}

(engl. Methoxy-acrylates)

Fungicidi iz ove grupe inhibiraju mitohondrijalnu respiraciju (disanje) gljiva blokiranjem transporta elektrona između citokroma b i citokroma c1 (kompleks III), na temelju čega su razvrstani u FRAC grupu C3. Navedeni mehanizam djelovanja dovodi do spriječavanja klijanja spora, kao i zaustavljanja porasta micelija i sporulacije kod osjetljivih fitopatogenih gljiva, zbog čega ovi fungicidi pokazuju protektivna, eradikativna, translaminarna i sistemična svojstva. Imaju visok rizik za razvoj rezistentnosti. Postoji mogućnost za pojavu unakrsne rezistentnosti sa drugim predstavnicima unutar FRAC grupe C3.

\subsubsection{Azoksistrobin}

Pripada novijoj generaciji fungicida s potpuno drugačijim mehanizmom djelovanja u odnosu na inhibitore biosinteze ergosterola. Suzbija uzročnike najvažnijih bolesti na vinovoj lozi, raznim povrtarskim biljkama i žitaricama, kao što su: plamenjača, pepelnica, crvena palež, crna pjegavost rozgve; te plamenjača i koncentrična pjegavost krumpira i rajčice, kao i plamenjača i pepelnica krastavaca, hrđa krizantema i pepelnica, hrđa, mrežasta pjegavost i siva pjegavost lista ječma. Zaštitu provoditi isključivo preventivno.

$$
\mathrm{LD}_{50}>\text { 5000. S.O. - III. }
$$

\subsubsection{Pikoksistrobin}

Fungicid širokog spektra djelovanja na žitaricama.

$\mathrm{LD}_{50}>$ 2000. S.O. - III.

Pripravak: Acanto Plus.

\subsection{Pirazol-karboksamidi}

Uvršteni su u C2 skupinu - inhibitori sukcinat dehidrogenaze. Na našem tržištu su dostupni pripravci na bazi slijedećih aktivnih tvari: fluksapiroksad, izopirazam i benzovindiflupir.

\subsubsection{Fluksapiroksad}

Aktivna tvar koja u Hrvatskoj ima dozvolu za tretiranje sjemena žitarica. Budući da je iz skupine inhibitora sukcinat dehidrogenaze, zbog cross-rezistentnosti s drugim aktivnim tvarima iz ove skupine potrebno je izbjegavati njihovu primjenu tijekom vegetacije ukoliko je sjeme tretirano pripravkom na bazi fluksapiroksada.

$\mathrm{LD}_{50}>5000$, S.O. - III.

\subsubsection{Izopirazam}

Izopirazam je preventivni fungicid koji djeluje na klijanje spora, inhibiciju rasta klične cijevi te sprečavanje prodiranja hife u biljno tkivo. Ima dozvolu za suzbijanje pepelnice na povrtnicama u zaštićenim prostorima.

$$
\mathrm{LD}_{50}>5000 \text {, S.O. }- \text { III. }
$$




\subsubsection{Benzovindiflupir}

Djelatna tvar benzovindiflupir se koristi kao fungicid u žitaricama. Djeluje kao inhibitor sukcinat-dehidrogenaze. Koristi se kod povoljnih uvjeta za razvoj bolesti.

$\mathrm{LD}_{50}>$ 5000, S.O. - III, K- OVP.

\subsubsection{Biksafen}

Aktivna tvar za suzbijanje uzročnika bolesti u žitaricama.

Pripravak: Ascra xpro

\subsubsection{Sedaksan}

Novija aktivna tvar koja se koristi za tretiranje sjemena žitarica.

$\mathrm{LD}_{50}>5050$, S.O. - III, K - OVP.

\subsection{Metoksi-karbamati ("Strobilurini")}

(engl. Methoxy-carbamates)

Metoksi-karbamati imaju isti mehanizam djelovanja kao i fungicidi iz grupa metoksi-akriata, oksimino actata i oksimino-acetamida ("strobilurina"), kao i iz grupa oksazolidindiona i imidazolinona, odnosno i oni inhibiraju mitohondrijalnu respiraciju (disanje) gljiva blokiranjem transporta elektrona između citokroma b i citokroma c1 (kompleks III), na temelju čega su razvrstani u FRAC grupu C3. Navedeni mehanizam djelovanja dovodi do spriječavanja klijanja spora, kao i zaustavljanja porasta micelija i sporulacije kod osjetljivih fitopatogenih gljiva, zbog čega ovi fungicidi pokazuju protektivna, eradikativna, translaminarna i sistemična svojstva. Imaju visok rizik za razvoj rezistentnosti. Postoji mogućnost za pojavu unakrsne rezistentnosti sa drugim predstavnicima unutar FRAC grupe C3.

\subsubsection{Piraklostrobin}

Djeluje na način da inhibira transport elektrona u respiratornom lancu (kompleks III), čime se sprječava klijanje spora. Na tržištu dostupan i u kombinaciji s drugim djelatnim tvarima. $\mathrm{LD}_{50}>$ 5000. S.O. - III. K - 42 dana vinova loza, ječam, 35 dana šećerna repa, 7-14 dana jabuka.

\subsection{Oksimino acetati ("Strobilurini")}

(engl. Oximino acetates)

Oksimino acetati imaju isti mehanizam djelovanja kao i fungicidi iz grupa metoksiakrilata, metoksi-karbamata i oksimino-acetamida ("strobilurina"), kao i iz grupa oksazolidindiona i imidazolinona, odnosno i oni inhibiraju mitohondrijalnu respiraciju (disanje) gljiva blokiranjem transporta elektrona između citokroma b i citokroma c1 (kompleks III), na temelju čega su razvrstani u FRAC grupu C3. Navedeni mehanizam djelovanja dovodi do spriječavanje klijanja spora, kao i zaustavljanja porasta micelija i sporulacije kod osjetljivih fitopatogenih gljiva, zbog čega ovi fungicidi pokazuju protektivna, eradikativna, translaminarna i sistemična svojstva. Imaju visok rizik za razvoj rezistentnosti. Postoji mogućnost za pojavu unakrsne rezistentnosti sa drugim predstavnicima unutar FRAC grupe C3. 


\subsubsection{Krezoksim-metil}

Djelatna tvar slična prirodnom strobilurinu - fungitoksičnoj izlučevini gljivice Strobilurus tenacellus. Registriran je za suzbijanje uzročnika čađave krastavosti plodova i pepelnice jabuke te pepelnice na vinovoj lozi.

$$
\mathrm{LD}_{50} \text { - 5000. S.O. - III. }
$$

\subsubsection{Trifloksistrobin}

Koristi se za suzbijanje uzročnika čađave krastavosti i pepelnice jabuke, pepelnice i plamenjače vinove loze, pjegavosti lista šećerne repe i drugih bolesti. U vinovoj lozi se primjenjuje od završetka cvatnje do formiranja bobica veličine zrna graška. Ne više od 4 prskanja tijekom vegetacije kako bi se izbjegla rana pojava rezistentnosti. Preventivno djeluje i na pojavu bolesti na jabukama tijekom skladištenja.

$\mathrm{LD}_{50}$ - 2000. S.O. - III.

\subsection{Oksimino-acetamidi ("Strobilurini")}

(engl. Oximino-acetamides)

Oksimino-acetamidi imaju isti mehanizam djelovanja kao i fungicidi iz grupa metoksikarbamata, metoksi-akrilata i oksimino actata ("strobilurina"), kao i iz grupa oksazolidindiona i imidazolinona, odnosno i oni inhibiraju mitohondrijalnu respiraciju (disanje) gljiva blokiranjem transporta elektrona između citokroma b i citokroma c1 (kompleks III), na temelju čega su razvrstani u FRAC grupu C3. Navedeni mehanizam djelovanja dovodi do spriječavanje klijanja spora, kao i zaustavljanja porasta micelija i sporulacije kod osjetljivih fitopatogenih gljiva, zbog čega ovi fungicidi pokazuju protektivna, eradikativna, translaminarna i sistemična svojstva. Imaju visok rizik za razvoj rezistentnosti. Postoji mogućnost za pojavu unakrsne rezistentnosti sa drugim predstavnicima unutar FRAC grupe C3.

\subsubsection{Dimoksistrobin}

Ima zaštitno i kurativno djelovanje.

$\mathrm{LD}_{50}>5000$, S.O.- III.

Pripravak: Pictor.

\subsection{Oksazolidindioni}

(engl. Oxazolidinediones)

Oksazolidindioni imaju isti mehanizam djelovanja kao i fungicidi iz grupa metoksiakrilata, metoksi-karbamata, oksimino actata i oksimino-acetamida ("strobilurina"), kao i iz grupe imidazolinona, odnosno i oni inhibiraju mitohondrijalnu respiraciju (disanje) gljiva blokiranjem transporta elektrona između citokroma b i citokroma c1 (kompleks III), na temelju čega su razvrstani u FRAC grupu C3. Imaju visok rizik za razvoj rezistentnosti. Postoji mogućnost za pojavu unakrsne rezistentnosti sa drugim predstavnicima unutar FRAC grupe C3. 


\subsubsection{Famoksadon}

U kombinaciji s cimoksanilom suzbija uzročnike plamenjače.

$\mathrm{LD}_{50}$ - 1333 (za pripravak). S.O. - III.

\subsection{Imidazolinoni}

(engl. Imidazolinones)

Imidazolinoni imaju isti mehanizam djelovanja kao i fungicidi iz grupa metoksi-akrilata, metoksi-karbamata, oksimino actata i oksimino-acetamida ("strobilurina"), kao i iz grupe oksazolidin-diona, odnosno i oni inhibirajumitohondrijalnu respiraciju (disanje) blokiranjem transporta elektrona između citokroma b i citokroma c1 (kompleks III), na temelju čega su razvrstani u FRAC grupu C3. Imaju visok rizik za razvoj rezistentnosti. Postoji mogućnost za pojavu unakrsne rezistentnosti sa drugim predstavnicima unutar FRAC grupe C3.

\subsubsection{Fenamidon}

Inhibitor disanja, zaštitnog je i kurativnog djelovanja.

$\mathrm{LD}_{50}>$ 2000. S.O. - III.

\subsection{Cianoimidazoli}

(engl. Cyanoimidazole)

Fungicidi iz ove grupe inhibiraju respiraciju (disanje) gljiva blokiranjem transporta elektrona između citokroma b i citokroma c1 (kompleks III), na temelju čega su razvrstani u FRAC grupu C4. Rezistentnost prema ovim fungicidima do sada nije poznata, ali se na temelju proučavanja model organizama smatra da u budućnosti mogu imati srednji do visok rizik.

\subsubsection{Ciazofamid}

Kontaktni - preventivni fungicid namijenjen za suzbijanje uzročnika plamenjače.

$\mathrm{LD}_{50}>$ 5000. S.O. - III.

\subsection{Sulfamoil-triazoli}

Fungicidi u ovoj skupini inhibiraju respiraciju gljiva blokiranjem transporta elektrona između citokroma a i citokroma c1 (kompleks III), zbog čega su razvrstani u FRAC grupu C4.

\subsubsection{Amisulbrom}

Koristi se za suzbijanje uzročnika plamenjače.

$\mathrm{LD}_{50}>5000$, S.O. - III. 


\subsection{Dinitrofenil krotonati}

(engl. Dinitrophenyl crotonates)

Fungicidi iz ove grupe inhibiraju mitohondrijalnu respiraciju (disanje) kod osjetljivih fitopatogenih gljiva prekidanjem oksidativne fosforilacije, na temelju čega su razvrstani u FRAC grupu C5. Kontaktni su fungicidi s protektivnim i kurativnim djelovanjem. Rezistentnost prema ovim fungicidima do sada nije poznata. Imaju i akaricidno djelovanje.

\subsubsection{Meptil-dinokap}

Komponenta dinokapa. Protektant s kurativnim i eradikativnim djelovanjem.

$\mathrm{LD}_{50}>2000$, S.O. - III.

\subsection{2,6-dinitroanilini}

(engl. 2,6-dinitroanilines)

2,6-dinitroanilini imaju isti mehanizam djelovanja kao i fungicidi iz grupe dinitrofenil krotonata, odnosno i oni inhibiraju mitohondrijalnu respiraciju (disanje) kod osjetljivih fitopatogenih gljiva prekidanjem oksidativne fosforilacije, na temelju čega su razvrstani u FRAC grupu C5. Djeluju preventivno, ali imaju dobru rezidualnu učinkovitost. Iskazuju slabu sistemičnu i kurativnu aktivnost. Rezistentnost prema ovim fungicidima do sada nije poznata, ali se smatra da u budućnosti mogu imati nizak rizik.

\subsubsection{Fluazinam}

Kontaktni fungicid, slab sistemik, ali dobrog rezidualnog djelovanja. Otporan na ispiranje kišom. Primjenjuje se na potpuno razvijenu lisnu masu krumpira.

$\mathrm{LD}_{50}>$ 5000. S.O. - III.

\subsection{Triazolo-pirimidilamini}

(engl. Triazolo-pyrimidyamine)

Fungicidi iz ove grupe inhibiraju podstranu stigmatelina kompleksa III i biosintezu fosfolipida, zbog čega su razvrstani u FRAC grupu C8.

\subsubsection{Ametoktradin}

Post-em fungicid, koji je snažan inhibitor staničnog disanja u kompleksu III. Kod nas ima dozvolu u kombiniranom pripravku za suzbijanje uzročnika plamenjače vinove loze.

$\mathrm{LD}_{50}>5000$, S.O. III. 


\subsection{Anilino-pirimidini}

(engl. Anilino-pyrimidines)

Fungicidi iz ove grupe inhibiraju biosintezu metionina i lučenje hidrolitičkih enzima što dovodi do spriječavanja sinteze proteina kod fitopatogenih gljiva, na temelju čega su razvrstani u FRAC grupu D1. Ciprodinil je sistemični fungicid koji se poslije folijarne primjene apsorbira i transportira akropetalnim putem, sustavom provodnih žila ksilema, dok pirimetanil ima preventivno i kurativno djelovanje. Spriječavaju penetraciju i porast micelija gljiva u i na površini lista. Koriste se za suzbijanje širokog spektra fitopatogenih gljiva. U svijetu je već utvrđena pojava rezistentnosti fitopatogenih gljiva iz roda Botrytis i Venturia prema ovim fungicidima. Imaju srednji rizik za razvoj rezistentnosti.

\subsubsection{Ciprodinil}

Fungicid s preventivnim i kurativnim djelovanjem na uzročnika čađave krastavosti.

Lokosistemik. Učinkovit i na pepelnicu i Monilia spp. Treba ga primijeniti od faze "mišjih ušiju" do kraja cvjetanja. Djelotvoran i na niskim temperaturama, a dva sata nakon prskanja prisutan je u biljci u cijelosti i nema opasnosti od ispiranja d.t. Prikladan u integriranim programima zaštite bilja.

$\mathrm{LD}_{50}>$ 2000. S.O. - III.

\subsubsection{Pirimetanil}

Djelatna tvar spriječava izlučivanje enzima patogenih gljiva neophodnih za proces infekcije i penetraciju kličnih cijevi u stanice domaćina. Djeluje kontaktno i translaminarno. Primjenjuje se preventivno i kurativno u suzbijanju uzročnika sive plijesni u velikom broju kultura. Jedan sat nakon prskanja sav je u biljci i nema opasnosti od ispiranja kišom.

$\mathrm{LD}_{50}$ - 4150. S.O. - III.

\subsection{Kinolini}

(engl. Quinolines)

Fungicidi iz ove grupe inhibiraju sintezu G-proteina što dovodi do zaustavljanja prijenosa i pretvaranja signala kod fitopatogenih gljiva, na temelju čega su razvrstani u FRAC grupu E1. Imaju preventivno i sporo sistemično djelovanje $\mathrm{s}$ akropetalnom i bazipetalnom pokretljivošću. Djeluju i parama. Imaju srednji rizik za razvoj rezistentnosti, iako ne pokazuju unakrsnu rezistentnost s drugim skupinama fungicida.

\subsubsection{Kinoksifen}

Erizificid s izraženim preventivnim djelovanjem, sporog sistemičnog djelovanja. Djeluje i parama. Ne pokazuje unakrsnu rezistentnost s drugim skupinama fungicida. Primjenjuje se od kraja cvatnje do zatvaranja grozdova. Ne upotrebljavati doze koje su veće od maksimalno dopuštenih.

$\mathrm{LD}_{50}$ - 2000. S.O. - III. T - 0,5. 


\subsubsection{8-hidroksikinolin}

Derivat kinolina koji inhibira sintezu RNA. Koristi se za suzbijanje biljnih bolesti u povrćarstvu.

$\mathrm{LD}_{50}$ - 2000. S.O. - III.

\subsection{Fenilpiroli}

(engl. Phenylpyrroles)

Fungicidi iz ove grupe inhibiraju enzim MAP/histidin-kinazu spriječavajući prenošenje i pretvaranje osmotskih signala, zbog čega inhibiraju klijanje spora, a u manjem stupnju i rast infekcijske hife i micelija kod fitopatogenih gljiva, na temelju čega su razvrstani u FRAC grupu E2. Nisu sistemici. Imaju preventivno, djelomično i kurativno, te dugo rezidualno djelovanje. Imaju mali do srednji rizik za razvoj rezistentnosti. 2.24.1. Fludioksonil U kombinaciji s ciprodinilom koristi se za suzbijanje uzročnika sive plijesni. Fludioksonil je fungicid s površinskim djelovanjem.

$\mathrm{LD}_{50}$ - 5000. S.O. - III. T - 2.

\subsection{1.a) Za tretiranje sjemena}

Suzbija uzročnika smrdljive snijeti pšenice, fuzarioze pšenice, ječma i kukuruza, kao i prugavost lišća i prašnu snijet ječma.

$\mathrm{LD}_{50}$ - 5000. S.O. - izvan skupine otrova.

\subsection{Dikarboksimidi}

(engl. Dicarboximides)

Fungicidi iz ove grupe inhibiraju enzim MAP/histidin-kinazu što dovodi do spriječavavanja prijenosa i pretvaranja osmotskih signala, zbog čega spriječava klijanje spora kod fitopatogenih gljiva, na temelju čega su razvrstani u FRAC grupu E3. Kontaktni su fungicidi s preventivnim djelovanjem. Utvrđena je pojava rezistentnosti fitopatogenih gljiva iz roda Botrytis, kao i iz nekih drugih rodova fitopatogenih gljiva prema ovim fungicidima. Imaju srednji do visok rizik za razvoj rezistentnosti te ih treba vrlo pažljivo koristiti. Postoji mogućnost za pojavu unakrsne rezistentnosti sa drugim predstavnicima unutar FRAC grupe E3.

\subsubsection{Iprodion}

Učinkovit u zaštiti od Monilia spp. na cvatu i plodovima na marelicama, breskvama, višnjama i šljivama (Monilia laxa, Monilia fructigena), kao i od Botrytis spp. na jagodama, kupinama, ribizlama, vinovoj lozi, suncokretu, uljanoj repici i drugim kulturama. Spriječava razvoj:

Rhizopus spp., Aspergillus spp., Penicillium spp., Phoma spp. i drugih bolesti.

$\mathrm{LD}_{50}$ - 3500. S.O. = III. 


\subsection{Karbamati}

(engl. Carbamates)

Fungicidi iz ove grupe inhibiraju propusnost staničnih membrana i sintezu masnih kiselina spriječavajući sintezu lipida i staničnih membrana kod fitopatogenih gljiva, na temelju čega su razvrstani u FRAC grupu F4. Sistemični su fungicidi s preventivnim djelovanjem. Rezistentnost prema ovim fungicidima do sada nije utvrđena, ali se smatra da u budućnosti mogu imati nizak do srednji rizik.

\subsubsection{Propamokarb-hidroklorid}

Uspješno suzbija fitopatogene gljive iz rodova: Pythium spp., Phythophtora spp., Plasmopara, Pseudoperonospora, Peronospora i Bremia. Zbog visokih rezidua ne smije se koristiti u drugom povrću. Tretiranje tla dopušteno samo jedanput tijekom vegetacije. Ne miješati s mankozebom i propinebom.

$$
\mathrm{LD}_{50} \text { - 2300. S.O. }=\text { III. }
$$

2.27. Amidi karboksilne kiseline

(engl. Carboxylic acid amides)

Fungicidi iz ove grupe inhibiraju biosintezu fosfolipida što spriječava sintezu lipida i staničnih membrana kod fitopatogenih gljiva, na temelju čega su razvrstani u FRAC grupu F5. Djeluju sistemično i kurativno stanične membrane kod pojedinih patogena iz razreda Oomycota. Rezistentnost prema fungicidima iz ove grupe je primijećena kod Plasmopara viticola, dok kod Phytophthora infestans ona još nije utvrđena. Imaju mali do srednji rizik za razvoj rezistentnosti. Među pripadnicima ove grupe može se pojaviti unakrsna rezistentnost.

\subsubsection{Dimetomorf (Cinnamic acid amides)}

Lokal sistemik za suzbijanje uzročnika plamenjače vinove loze, krumpira i krastavca. Dimetomorf djeluje tako što ometa stvaranje opne stanica patogene gljive u svim razvojnim fazama bolesti. Ova aktivna tvar već poslije 60 minuta prodire duboko u tretirane dijelove biljke i odande se širi lokalno sistemično, čime su obuhvaćene već najranije faze bolesti, kada simptomi još nisu vidljivi (1-2 dana). Odlikuje se vrlo snažnim djelovanjem na nastanak novih spora, čime se prekida širenje uzročnika plamenjače u vinogradu.

$\mathrm{LD}_{50}$ - 2000. S.O. - III.

\subsubsection{Iprovalikarb (Valinamide carbamates)}

Inhibira rast klične cijevi zoospora i sporangija, rast hifa, a time i sporulaciju kod osjetljivih fitopatogenih gljiva. Zahvaljujući novoj kemijskoj strukturi prema ovoj djelatnoj tvari za sada nije utvrđena pojava rezistentnosti. Ima vrlo izraženo kretanje prema vrhu biljke putem provodnog sustava tako da pripravak dospijeva i u mlade listove koji u vrijeme prskanja još nisu bili formirani. Suzbija uzročnike plamenjače vinove loze, krumpira, rajčice i duhana. Ima izraženo preventivno i kurativno djelovanje.

$\mathrm{LD}_{50}$ - 5000. S.O. $=$ III. 


\subsubsection{Mandipropamid (Mandelic acid amides)}

Odlikuje ga visoka djelotvornost za suzbijanje biljnih patogena iz razreda Oomycota i otpornost na ispiranje kišom. Ima jače translaminarno djelovanje od ostalih amida karboksilne kiseline. Mandipropamid se čvrsto veže na voštanu prevlaku lista i bobica i potom se postupno otpušta u tkivo bobica i lišća (LOK + FLO djelovanje).

\subsubsection{Bentiavalikarb (Valinamide carbamates)}

Pripada FRAC grupi H5. Registriran je kombinirani pripravak za suzbijanje uzročnika plamenjače na vinovoj lozi i rajčici.

$\mathrm{LD}_{50}>5000$, S.O. III.

Pripravak: Vincare

\subsection{Imidazoli}

(engl. Imidazoles)

\section{Inhibitori biosinteze ergosterola (grupa I)}

Imidazoli imaju isti mehanizam djelovanja kao i fungicidi iz grupe pirimidina i triazola, odnosno i oni inhibiraju biosintezu ergosterola u staničnim membranama kod fitopatogenih gljiva, na temelju čega su razvrstani u FRAC grupu G1. Djeluju na drugom mjestu u odnosu na predstavnike inhibitora biosinteze ergosterola iz grupe II i III, budući da inhibiraju procese demetilacije u stanicama gljiva tako što blokiraju enzim C14-demetilazu (erg11/ cyp51) zbog čega dolazi do spriječavanja demetilacije spoja 24-metilen hidrolanosterola iz kojeg nastaje ergosterol. Bez njega membrane stanica i hife gljiva gube sposobnost regulacije tvari zbog čega dolazi do njihovog odumiranja. Sistemični su fungicidi s preventivnim i kurativnim djelovanjem. Pokazuju širok spektar djelovanja na mnoge fitopatogene gljive.

Imaju srednji rizik za pojavu rezistentnosti. Neke gljive su već razvile mehanizme rezistentnosti prema ovoj grupi fungicida. Među predstavnicima ove grupe može doći do pojave unakrsne rezistentnosti, dok unakrsna rezistentnost s predstavnicima grupa II i III inhibitora biosinteze ergosterola nije utvrđena.

\subsubsection{Imazalil}

Koristi se za zaštitu plodova agruma nakon berbe. Na ambalažu tretiranih agruma potrebno je navesti slijedeće upozorenje: "UPOZORENJE: Kora agruma nije za jelo. Tretirano imazalilom". $\mathrm{LD}_{50}-227-343$

\subsubsection{Prokloraz}

Nema jako izraženo sistemično djelovanje. Suzbija uzročnike bolesti žitarica:

Pseudocercosporella herpotrichoides, Pyrenophora teres, Rhynchosporium secalis, Septoria spp., a smanjuje napad pepelnice i Fusariuma na klasu. Na suncokretu suzbija: Alternaria spp., Botrytis cinerea, Sclerotinia sclerotiorum i Phomopsis helianthi.

$$
\mathrm{LD}_{50} \text { - 1600. S.O. - III. }
$$




\subsection{Triazoli}

(engl. Triazoles)

\section{Inhibitori biosinteze ergosterola (grupa I)}

Triazoli imaju isti mehanizam djelovanja kao i fungicidi iz grupe pirimidina i imidazola, odnosno i oni inhibiraju biosintezu ergosterola u staničnim membranama kod fitopatogenih gljiva, na temelju čega su razvrstani u FRAC grupu G1. Djeluju na drugom mjestu u odnosu na predstavnike inhibitora biosinteze ergosterola iz grupe II i III, budući da inhibiraju procese demetilacije u stanicama gljiva tako što blokiraju enzim C14-demetilazu(erg11/ cyp51) zbog čega dolazi do spriječavanja demetilacije spoja 24-metilen hidrolanosterola iz kojeg nastaje ergosterol. Bez njega membrane stanica i hife gljiva gube sposobnost regulacije tvari zbog čega dolazi do njihovog odumiranja. Sistemični su fungicidi s preventivnim i kurativnim djelovanjem. Pokazuju širok spektar djelovanja na mnoge fitopatogene gljive. Imaju srednji rizik za pojavu rezistentnosti. Neke gljive su već razvile mehanizme rezistentnosti prema ovoj grupi fungicida. Među predstavnicima ove grupe može doći do pojave unakrsne rezistentnosti, dok unakrsna rezistentnost s predstavnicima grupa II i III inhibitora biosinteze ergosterola nije utvrđena.

\subsubsection{Ciprokonazol}

Sistemik širokog spektra. U pripravcima dolazi u kombinacijama sa strobilurinima, benzimidazolima, propikonazolom. Suzbija bolesti žitarica: Blumeria (Erysiphe) graminis, Puccinia spp., Septoria spp., Rhynchosporium secalis, Pyrenophora teres, te smanjuje napad Fusarium spp. na klasu. Na šećernoj repi suzbija uzročnike sive pjegavosti i pepelnice.

S.O. - III. $\mathrm{LD}_{50}-1200$.

\subsubsection{Difenkonazol}

Sistemični fungicid namijenjen za suzbijanje uzročnika čađave krastavosti i pepelnicejabuke. $\mathrm{LD}_{50}$ - 1453. S.O. - III.

\subsection{2.a) Za tretiranje sjemena}

Na sjemenu pšenice suzbija: Tilletia caries, Tilletia foetida, Ustilago tritici, Stagnospora Septoria nodorum, Cochliobolus sativus i smanjuje zarazu sa Fusarium spp. Za sve ozime i jare te mekane i tvrde sorte pšenice.

$\mathrm{K}-\mathrm{OVP}$.

\subsubsection{Epoksikonazol}

Namijenjen je za suzbijanje uzročnika bolesti žitarica: Blumeria (Erysiphe) graminis, Puccinia spp., Pyrenophora teres, Rhynchosporium secalis i Septoria spp. Smanjuje zarazu s Fusarium spp.

$$
\mathrm{LD}_{50} \text { - 3160. S.O. - III. }
$$




\subsubsection{Fenbukonazol}

Sistemik. Usvaja se tijekom 2-4 sata nakon prskanja. Ima snažno kurativno i dugo djelovanje. Nije otrovan pa se može rabiti i u punoj cvatnji.

$\mathrm{LD}_{50}>$ 2000. S.O. - III.

\subsubsection{Flutriafol}

Namijenjen je suzbijanju uzročnika bolesti žitarica: Blumeria (Erysiphe) graminis, Puccinia spp., Pyrenophora teres te smanjuje zarazu sa Septoria spp. i Fusarium spp. na klasu.

Kombiniran s karbendazimom ima širi spektar. Suzbija uzročnike pjegavosti lista, pepelnice i hrđe šećerne repe. Na suncokretu suzbija uzročnike bijele truleži, truleži glava i sive pjegavosti stabljike.

$\mathrm{LD}_{50}$ - 1140. (za miša 365). S.O. - III.

\subsubsection{Metkonazol}

Kontaktno-sistemičan fungicid. Suzbija najvažnije uzročnike bolesti žitarica: Blumeria (Erysiphe) graminis, Puccinia spp., Pyrenophora teres, Rhynchosporium secalis i Septoria spp. i smanjuje zarazu Fusarium spp. U uljanoj repicu suzbija uzročnike koncentrične pjegavosti komuški, bijele truleži i suhe trulež, te djeluje i kao regulator rasta.

$\mathrm{LD}_{50}$ - 1459. S.O. $=$ III.

\subsubsection{Miklobutanil}

Fungicid s preventivnim, kurativnim, a kod uzročnika čađave krastavosti i eradikativnim efektom. Namijenjen je suzbijanju uzročnika pepelnice jabuke, vinove loze, ruže i krastavca.

$\mathrm{LD}_{50}$ - 2800. S.O. - III.

\subsubsection{Penkonazol}

Za preventivno i kurativno suzbijanje uzročnika pepelnice jabuke i vinove loze.

$\mathrm{LD}_{50}$ - 2125. S.O. - III. K - 21 dan jabuka i kruška; 35 dana vinova loza.

\subsubsection{Propikonazol}

Sistemični protektivni i kurativni fungicid za suzbijanje uzročnika bolesti pšenice i ječma (Blumeria/Erysiphe graminis, Septoria spp., Puccinia spp., Rhynchosporium secalis), te pepelnice vinove loze.

$\mathrm{LD}_{50}$ - 1517. S.O. - III.

\subsubsection{Protiokonazol}

Suzbija najvažnije uzročnike bolesti žitarica: Blumeria (Erysiphe) graminis, Puccinia spp., Septoria spp., Rhynchosporium secalis, Pyrenophora teres te značajnije smanjuje napad Fusarium spp. na klasu. 


\subsubsection{0.a) Za tretiranje sjemena}

U kontaktno-sistemičnom pripravku za suzbijanje uzročnika biljnih bolesti koje se prenose sjemenom na pšenici, ječmu, raži i zobi.

LD $_{50}$ - 6200. S.O. - III. K - OVP.

\subsubsection{Tebukonazol}

Sistemik širokog spektra. Suzbija uzročnike bolesti žitarica: Blumeria (Erysiphe) graminis, Puccinia spp., Septoria spp., Rhynchosporium secalis, Pyrenophora teres te značajnije smanjuje napad Fusariuma na klasu (dopuštena su 2 tretiranja). Suzbija uzročnike čađave krastavosti i pepelnice jabuke te paleži cvijeta koštičavih voćaka. Na uljanoj repici i suncokretu suzbija: Alternaria spp., Botrytis cinerea i Sclerotinia sclerotiorum.

$\mathrm{LD}_{50}$ - 3300. S.O. - III. K - 7 višnja, trešnja; 14 breskve, nektarine; 15 šljiva; 21 lubenica, dinja, krastavac, paprika, rajčica; 28 jabuka; 42 žito i vinova loza; 56 uljana repica i suncokret.

Šljiva i trešnja samo u cvatnji. Vinova loza do 3 tretiranja.

\subsubsection{1.a) Za tretiranje sjemena}

Triazolni sistemik. Spektar suzbijanja bolesti analogan triadimenolu, ali je aktivniji. Za tretiranje sjemena pšenice - protiv uzročnika smrdljive snijeti, prašne snijeti, fuzarioza; ječma za suzbijanje uzročnika prašne snijeti ječma; raži - za suzbijanje uzročnika fuzariozne paleži klice; zobi - za suzbijanje uzročnika prašne snijeti zobi i uzročnika fuzariozne paleži klice.

$\mathrm{LD}_{50}$ - 335. S.O. - III. K - OVP.

\subsubsection{Tetrakonazol}

Sistemični fungicid.

$\mathrm{LD}_{50}-1150$.

\subsubsection{Triadimenol}

Metabolit triadimefona sa sličnim spektrom. Dopuštena najviše dva tretiranja.

LD $_{50}$ - 700-1500. S.O. - III. K - 7 krastavac, 35 pšenica i ječam.

\subsection{Morfolini}

(engl. Morpholines)

\section{Inhibitori biosinteze ergosterola (grupa II)}

Fungicidi iz ove grupe inhibiraju biosintezu ergosterola u staničnim membranama kod fitopatogenih gljiva. Djeluju na drugom mjestu u odnosu na predstavnike inhibitora biosinteze ergosterola grupe I i III, budući da inhibiraju drugačije enzimatske procese - enzime $\Delta^{14}$ reduktazu i $\Delta^{8}--->\Delta^{7}$-izomerazu u biosintezi ergosterola (erg24, erg2), na temelju čega su razvrstani u FRAC grupu G2. Sistemičnog su djelovanja.

Imaju mali do srednji rizik za pojavu rezistentnosti. Među predstavnicima ove grupe može doći do pojave unakrsne rezistentnosti, dok unakrsna rezistentnost s predstavnicima grupa I i III inhibitora biosinteze ergosterola nije utvrđena. 


\subsubsection{Fenpropimorf}

Suzbija uzročnike hrđe i pepelnice na pšenici i ječmu. Kombinacije imaju širi spektar.

$\mathrm{LD}_{50}$ - 3000. S.O. - III. K - 42 dana pšenica i ječam.

Pripravak: Opus Team.

\subsection{Piperidini}

(engl. Piperidines)

\section{Inhibitori biosinteze ergosterola (grupa II)}

Fungicidi iz ove grupe inhibiraju biosintezu ergosterola u staničnim membranama kod fitopatogenih gljiva. Djeluju na drugom mjestu u odnosu na predstavnike inhibitora biosinteze ergosterola grupe I i III, budući da inhibiraju drugačije enzimatske procese - enzime $\Delta^{14}$ reduktazu i $\Delta^{8}$---> $\Delta^{7}$-izomerazu u biosintezi ergosterola (erg24, erg2), na temelju čega su razvrstani u FRAC grupu G2. Sistemičnog su djelovanja.

Imaju mali do srednji rizik za pojavu rezistentnosti. Među predstavnicima ove grupe može doći do pojave unakrsne rezistentnosti, dok unakrsna rezistentnost s predstavnicima grupa I i III inhibitora biosinteze ergosterola nije utvrđena.

\subsubsection{Fenpropidin}

Fenpropidin se koristi za suzbijanje uzročnika žutosmeđe pjegavosti lista, pepelnice, smeđe i žute hrđe i smeđe pjegavosti lista pšenice, te pepelnice, smeđe hrđe, mrežaste pjegavosti i sive pjegavosti ječmu, sive pjegavosti lista ječma i pepelnice na vinovoj lozi.

K-OVP.

\subsection{Spiroketalamini}

(engl. Spiroketalamines)

\section{Inhibitori biosinteze ergosterola (grupa II)}

Spiroketalamini imaju isti mehanizam djelovanja kao i fungicidi iz grupe morfolina, odnosno i oni inhibiraju biosintezu ergosterola u staničnim membranama kod fitopatogenih gljiva. Djeluju na drugom mjestu u odnosu na predstavnike inhibitora biosinteze ergosterola grupe I i III, budući da inhibiraju drugačije enzimatske procese - enzime $\Delta^{14}$-reduktazu i $\Delta^{8}$---> $\Delta^{7}$-izomerazu u biosintezi ergosterola (erg24, erg2), na temelju čega su razvrstani u FRAC grupu G2. Sistemičnog su djelovanja.

Imaju mali do srednji rizik za pojavu rezistentnosti. Među predstavnicima ove grupe može doći do pojave unakrsne rezistentnosti, dok unakrsna rezistentnost s predstavnicima grupa I i III inhibitora biosinteze ergosterola nije utvrđena. 


\subsubsection{Spiroksamin}

Spiroksamin se koristi za suzbijanje uzročnika pepelnice, hrđe na pšenici i ječmu, sive pjegavosti lista ječma i pepelnice na vinovoj lozi. Kombinacija ima širi spektar i ispoljava djelovanje na Septoria spp. na listu i klasu, te na smanjenje zaraze sa Fusarium spp. na klasu.

$\mathrm{LD}_{50}$ - 595. S.O. - III. K-35 dana vinske sorte, 14 dana stolne sorte

\subsection{Hidroksianilidi}

(engl. Hydroxyanilides)

\section{Inhibitori biosinteze ergosterola (grupa III)}

Fungicidi iz ove grupe inhibiraju biosintezu ergosterola u staničnim membranama kod fi topatogenih gljiva. Djeluju na drugom mjestu u odnosu na predstavnike inhibitora biosinteze ergosterola iz grupe I i II, budući da inhibiraju enzim 3-keto reduktazu(erg27)i proces C4demetilacije u biosintezi ergosterola u stanicama gljiva,na temelju čega su razvrstani u FRAC grupu G3.

Imaju mali do srednji rizik za razvoj rezistentnosti, no potrebno je voditi brigu o eventualnoj pojavi rezistentnosti.

\subsubsection{Fenheksamid}

Botriticid iz nove kemijske grupe namijenjen suzbijanju uzročnika sive plijesni u: vinovoj lozi, jagodama, voću, povrću i ukrasnom bilju. Djeluje i na Monilia spp. i Sclerotinia spp. Potpuno drugačiji u odnosu na dosad poznate botriticide. Djeluje preventivno i dugotrajno. $\mathrm{LD}_{50}>$ 5000. S.O. - III.

\subsection{Ditiokarbamati}

(engl. Dithiocarbamates)

Fungicidi iz ove grupe djeluju na više različitih načina („Multi-site activity“), na temelju čega su razvrstani u FRAC grupu M3. Imaju kontaktno i protektivno djelovanje (nesistemici). Djeluju na veliki broj fitopatogenih gljiva. Često se kombiniraju sa sistemičnim fungicidima čime se postiže efikasnija zaštita uzgajanih biljaka.

Smatraju se grupom malog rizika za razvoj rezistentnosti. Nema pojave unakrsne rezistentnosti s drugim fungicidima koji djeluju na više različitih načina (,Multi-site activity“) iz FRAC grupa M1-M9, tj. sa fungicidima na bazi bakra i sumpora, kao i fungicidima iz grupa ftalimida, klornitrila, sulfamida, guanidina i kinona.

\subsubsection{Ciram}

Rabi se za premazivanje rana. Pridržavati se uputa o primjeni.

$\mathrm{LD}_{50}$ - 1400. S.O. - III. 


\subsubsection{Mankozeb}

Kontaktni fungicid. Suzbija uzročnike čađave krastavosti jabuke i kruške, plamenjače vinove loze i krumpira, hrđe i septorioze strnih žita i drugih bolesti.

$\mathrm{LD}_{50}$ - 6750. S.O. - III.

\subsubsection{Metiram}

Kontaktni fungicid širokog spektra djelovanja protiv uzročnika bolesti vinove loze, voćaka, povrtarskih biljaka, suncokreta i ukrasnog bilja. Na suncokretu dva, a rajčici tri puta tijekom vegetacije.

$\mathrm{LD}_{50}>10.000$. S.O. - III.

\subsubsection{Propineb}

Koristi se protiv uzročnika plamenjače vinove loze (Plasmopara viticola), plamenjače krumpira i rajčice (Phytophthora infestans), plamenjače duhana (Peronospora tabaci), čađave krastavosti jabuke i kruške (Venturia inaequalis, Venturia pirina) i drugih bolesti: Alternaria solani, Botrytis cinerea, Diplocarpon rosae, Peronospora tabacina, Phomopsis viticola, Pseudoperonospora humuli, Pseudopeziza tracheiphila.

$\mathrm{LD}_{50}$ - 8500. S.O. - III.

\subsubsection{Tiram}

Prvenstveno štiti sjeme od parazitskih i saprofitskih gljivica kao što su: Aspergillus spp., Fusarium spp., Penicillium spp., Rhizopus spp. i Tilletia spp. Nadražuje kožu i sluznicu.

$\mathrm{LD}_{50}$ - 780-865. S.O. - II. K - OVP.

Pripravak: Cabrio Top, Polyram DF.

\subsection{5. a) Za tretiranje sjemena}

Pripravak: Vitavax 200 FF.

\subsection{Ftalimidi}

(engl. Phthalimides)

Fungicidi iz ove grupe djeluju na više različitih načina („Multi-site activity“), na temelju čega su razvrstani u FRAC grupu M4. Imaju kontaktno i protektivno djelovanje (nesistemici). Djeluju na veliki broj fitopatogenih gljiva. Često se kombiniraju sa sistemičnim fungicidima čime se postiže efikasnija zaštita uzgajanih biljaka.

Smatraju se grupom malog rizika za razvoj rezistentnosti. Nema pojave unakrsne rezistentnosti s drugim fungicidima koji djeluju na više različitih načina (,Multi-site activity“) iz FRAC grupa M1-M9, tj. sa fungicidima na bazi bakra i sumpora, kao i fungicidima iz grupa ditiokarbamata, kloronitrila, sulfamida, guanidina i kinona. 


\subsubsection{Folpet}

U parazitskoj gljivi ometa djelovanje brojnih enzima zbog čega nastaju smetnje u metabolizmu ugljičnih hidrata, aminokiselina i fosfata. Uspješno suzbija uzročnike mnogih najštetnijih bolesti u vinogradima, voćnjacima i uzgajalištima cvijeća. U spektru obuhvaća: Alternaria spp., Botrytis cinerea, Phomopsis viticola, Plasmopara viticola, Venturia inaequalis i druge.

$$
\mathrm{LD}_{50} \text { - 10.000. S.O. - III. }
$$

\subsubsection{Kaptan}

Djelatna tvar površinskog djelovanja. Suzbija uzročnike najopasnijih bolesti na voću, vinovoj lozi, povrću i cvijeću. Najdjelotvorniji u preventivnoj primjeni protiv uzročnika čađave krastavosti.

$$
\text { LD } 50 \text { - 9000. S.O. - III. }
$$

\subsection{2.a) Za tretiranje sjemena}

Suzbija uzročnike: Fusarium spp., Ustilago maydis, Ascochyta spp., Colletotrichum spp. i druge uzročnike bolesti na sjemenu kukuruza.

\subsection{Kloronitrili}

(engl. Chloronitriles)

Fungicidi iz ove grupe djeluju na više različitih načina ("Multi-site activity“), na temelju čega su razvrstani u FRAC grupu M5. Imaju kontaktno i protektivno djelovanje (nesistemici). Djeluju na veliki broj fitopatogenih gljiva.

Smatraju se grupom malog rizika za razvoj rezistentnosti. Nema pojave unakrsne rezistentnosti s drugim fungicidima koji djeluju na više različitih načina („,Multi-site activity“) iz FRAC grupa M1-M9, tj. sa fungicidima na bazi bakra i sumpora, kao i fungicidima iz grupa ditiokarbamata, ftalimida, sulfamida, guanidina i kinona.

\subsubsection{Klortalonil}

Jedan od najvažnijih kontaktnih fungicida širokog spektra djelovanja i primjenjiv u velikom broju kultura. Djeluje preventivno inhibiranjem klijanja spora.

$\mathrm{LD}_{50}$ - 5000. S.O. - III.

\subsection{Guanidini}

(engl. Guanidines)

Fungicidi iz ove grupe djeluju na više različitih načina ("Multi-site activity"), na temelju čega su razvrstani u FRAC grupu M7. Preventivni i kurativni fungicidi lokalne sistemičnosti.

Guanidini pripadaju grupi fungicida s niskim rizikom za razvoj rezistentnosti, no pojava rezistentnosti Venturia inaequalis na dodin upućuje da dodin možda nije inhibitor na više mjesta djelovanja. Nema pojave unakrsne rezistentnosti s drugim fungicidima koji djeluju na više 
različitih načina ("Multi-site activity") iz FRAC grupa M1-M9, tj. sa fungicidima na bazi bakra i sumpora, kao i fungicidima iz grupa ditiokarbamata, ftalimida, kloronitrila, sulfamida i kinona.

\subsubsection{Dodin}

Sistemik s protektivnim i eradikativnim djelovanjem. Koristi se protiv uzročnika čađave krastavosti jabuke, kovrčavosti lista breskve, crvene paleži lišća ribizla i kozičavost lišća višnje i trešnje.

LD $_{50}$ - 851. S.O. - III. 75 dana breskva; 60 dana jabuka i kruška; 14 višnja i trešnja

\subsection{Kinoni}

(engl. Quinones)

Fungicidi iz ove grupe djeluju na više različitih načina („Multi-site activity“), na temelju čega su razvrstani u FRAC grupu M9. Imaju preventivno i djelomično kurativno djelovanje.

Smatraju se grupom malog rizika za razvoj rezistentnosti. Nema pojave unakrsne rezistentnosti s drugim fungicidima koji djeluju na više različitih načina („Multi-site activity“) iz FRAC grupa M1-M7, tj. sa fungicidima na bazi bakra i sumpora, kao i fungicidima iz grupa ditiokarbamata, ftalimida, kloronitrila, sulfamida i guanidina.

\subsubsection{Ditianon}

Fungicid niskog rizika na razvijanje rezistentnosti. Djeluje kao protektant i djelomično kurativno. Koristi se za suzbijanje uzročnika čađave krastavosti jabuke, plamenjače i crne pjegavosti rozgve vinove loze, lisne pjegavosti višnje i kovrčavosti i šupljikavost lista breskve. Može nadražiti kožu i sluzokožu. Može se primijeniti u svim razvojnim fazama jabuke i kruške. Breskve samo do faze neposredno prije početka bubrenja $(\mathrm{B} / \mathrm{C})$.

$\mathrm{LD}_{50}$ - 300. S.O. - III.

\subsection{Cianoacetamid-oksimi}

(engl. Cyanoacetamide-oxime)

Mjesto djelovanja fungicida iz ove grupe je nepoznato. Odlikuju se preventivnim i kurativnim djelovanjem i ograničenom translaminarnom sistemičnošću. Imaju mali do srednji rizik za pojavu rezistentnosti. Ipak se preporučuje provođenje mjera za nadzor nad pojavom rezistentnosti.

\subsubsection{Cimoksanil}

Kontaktna djelatna tvar translaminarne sistemičnosti za suzbijanje uzročnika plamenjače vinove loze, krumpira i rajčice. Postoje samo kombinirani pripravci. Dopuštena do 4 prskanja tijekom vegetacije.

$$
\text { LD } 50 \text { - 960. S.O. - III. }
$$




\subsection{Etil fosfonati}

(engl. Ethyl phosphonates)

Mjesto djelovanja fungicida iz ove grupe je nepoznato. To su sistemični fungicidi s protektivnim i kurativnim djelovanjem. Djeluju na fitopatogene gljive iz razreda Oomycota (Phytophthora spp., Pythium spp., Plasmopara spp., Peronospora spp., Pseudoperonospora spp. i Bremia spp.). Niskog su rizika za razvoj rezistentnosti.

\subsubsection{Fosetil-aluminij}

Fungicid s površinskim uzlaznim i silaznim sistemičnim djelovanjem. Suzbija uzročnika plamenjače na vinovoj lozi, krastavcima i drugim iz fam. Cucurbitaceae, salati i hmelju. Ne djeluje na uzročnika plamenjače krumpira. Učinkovit je i na uzročnika bakterijske paleži jabučastih voćaka (Erwinia amylovora).

$\mathrm{LD}_{50}$ - 7080. S.O. - III.

\subsection{Kinazolinoni}

(engl. Quinazolinone)

Mjesto djelovanja fungicida iz ove grupe je nepoznato, na temelju čega su razvrstani u FRAC grupu U7. Odlikuju se preventivnim i kurativnim djelovanjem i lokalnom sistemičnosti. Poznata je pojava rezistentnosti prema fungicidima iz ove grupe. Imaju srednji rizik za pojavu rezistentnosti, zbog čega je potrebno provoditi preporuke FRAC-a (Fungicide Resistance Action Committee) pri korištenju ovog fungicida. Utvrđena je pojava unakrsne rezistentnosti Uncinula necator prema fungicidima na bazi prokinazida i fungicidima na bazi djelatne tvari kinoksifen, dok ta pojava kod Blumeria (Erysiphe) graminis nije utvrđena..

\subsubsection{Prokinazid}

Lokosistemični fungicid translaminarnog kretanja, preventivnog i kurativnog učinka, namijenjen suzbijanju uzročnika pepelnice vinove loze (Uncinula necator). Osjetljiv je na fotolizu.

$\mathrm{LD}_{50}$ - 2000. S.O. - III .

\subsection{Benzofenoni}

(engl. Benzophenone)

Mjesto djelovanja fungicida iz ove grupe je još uvijek nepoznato, na temelju čega su razvrstani u FRAC grupu U8. Smatra se da utječu na organizaciju ili polarizaciju aktin cikloskeletona. To su lokosistemični fungicidi s protektivnim, kurativnim i eradikativnim (antisporulacijskim) djelovanjem. Benzofenoni su nova grupa fungicida, namijenjena za suzbijanje uzročnika pepelnice. Rezistentnost prema fungicidima iz ove grupe nije poznata. 


\subsubsection{Metrafenon}

Lokosistemični fungicid translaminarnog kretanja, preventivnog i kurativnog učinka, namijenjen suzbijanju uzročnika pepelnice vinove loze (Uncinula necator).

$\mathrm{LD}_{50}>5000$, S.O. III.

\subsection{Benzoilpiridini}

\subsubsection{Piriofenon}

Fungicid translaminarnog djelovanja. Ima preventivno i kurativno djelovanje na uročnika pepelnice.

$\mathrm{LD}_{50}>2000$

\subsection{Fenil-acetamidi}

\subsubsection{Ciflufenamid}

Fungicid nepoznatog načina djelovanja. Registriran je u kombiniranom pripravku za suzbijanje uzročnika pepelnice na vinovoj lozi.

$\mathrm{LD}_{50}>5000$, S.O. III.

Pripravak: Dynali.

\section{B) ANORGANSKI FUNGICIDI}

\subsection{Fungicidi na osnovi bakra $(\mathrm{Cu})$}

(engl. Copper fungicides)

Fungicidi na bazi bakra djeluju na više različitih načina (,Multi-site activity“), na temelju čega su razvrstani u FRAC grupu M1. Imaju kontaktno i protektivno djelovanje (nesistemici). Imaju širok spektar djelovanja za suzbijanje uzročnika bolesti voćaka, vinove loze, povrća i hmelja. Koriste se i za premazivanje rana nakon rezidbe. Često se kombiniraju sa sistemičnim fungicidima čime se postiže efikasnija zaštita uzgajanih biljaka. Na osjetljivim sortama vinove loze mogu izazvati palež za vlažnog i hladnog vremena. Na jabučastom voću smiju se koristiti do početka cvatnje, a na koštičavom voću samo za mirovanja vegetacije (za zimsko prskanje u 2 puta jačim koncentracijama od navedenih za prskanje u vegetaciji). Ovo se odnosi i na kombinacije s organskim fungicidima.

Smatraju se grupom malog rizika za razvoj rezistentnosti. Nema pojave unakrsne rezistentnosti s drugim fungicidima koji djeluju na više različitih načina (,Multi-site activity“) iz FRAC grupa M2-M9, tj. sa fungicidima na bazi sumpora, kao i fungicidima iz grupa ditiokarbamata, ftalimida, kloronitrila, sulfamida, guanidina i kinona. 


\subsubsection{Bakarni (I) oksid}

Preventivni fungicid i baktericid za suzbijanje uzročnika plamenjače, pjegavosti lista i čađave krastavosti jabuke, bakterijske paleži jabuke, kovrčavostilišća breskve, paunovog oka masline i drugih bolesti.

$\mathrm{LD}_{50}$ - 261. S.O. - III. K - 14 dana krumpir, lubenica, rajčica; 28 bundeva; 35 vinova loza; OVP jabuka, breskva, krastavci; 56 maslina.

\subsubsection{Bakarni oksiklorid}

Koristi se za suzbijanje uzročnika plamenjače vinove loze, rajčice, krumpira, luka, krastavaca; kovrčavosti i šupljikavosti lista breskve; čađave krastavosti jabuke i kruške. Na koštičavim voćkama dopuštena primjena samo u vrijeme mirovanja vegetacije. Lakše se ispiru kišom nego bordoška juha.

$\mathrm{LD}_{50}$ - 700. S.O. - III. K - 14 dana krumpir, rajčica, hmelj; 21 dan luk i grah; 35 dana vinova loza; 56 dana maslina. Karenca je kod voćaka ograničena vremenom primjene.

\subsubsection{Bakarni hidroksid}

Djeluje na način da inhibira enzimatski sustav patogena.

$\mathrm{LD}_{50}-489$.

\subsubsection{Bakar hidroksid - kalcij sulfat kompleks}

\subsubsection{Kombinacije bakra i organskih fungicida}

Pripravak: Ridomil Gold plus 42,5 WP, Ridomil Gold R, Curzate B WG, Galben C.

\subsubsection{Kombinacije bakra i mineralnih ulja}

Za suzbijanje uzročnika bolesti jezgričavog i koštičavog voća (tzv. "plavo pranje"), štitastih i lisnih ušiju, crvenog pauka i drugih štetnika koji prezimljuju na voćkama i vinovoj lozi. Primjena samo za mirovanja vegetacije: Neznatno opasni.

\section{S. O. - III. K - OVP.}

\subsection{Fungicidi na osnovi sumpora (S)}

(engl. Sulphur fungicides)

Fungicidi na bazi sumpora djeluju na više različitih načina („Multi-site activity“), na temelju čega su razvrstani u FRAC grupu M2. Ta se sredstva ponajprije koriste za suzbijanje uzročnika pepelnice na vinovoj lozi, jabukama, breskvama, krastavcima i drugim biljnim vrstama. Djeluju i na uzročnike nekih drugih bolesti, kao što je npr. čađava krastavost jabuke, kao i na grinje. Kod viših temperatura mogu prouzročiti palež biljaka.

Smatraju se grupom malog rizika za razvoj rezistentnosti. Nema pojave unakrsne rezistentnosti s drugim fungicidima koji djeluju na više različitih načina („Multi-site activity“) iz FRAC grupa M1-M9, tj. sa fungicidima na bazi bakra, kao i fungicidima iz grupa ditiokarbamata, ftalimida, kloronitrila, sulfamida, guanidina i kinona. 
$\mathrm{LD}_{50}>5000$. S. O. - izvan skupine otrova. K - 7 krastavci u polju i zaštićenom prostoru, grašak, grah, hmelj; 14 ostalo povrće i voće; 35 vinova loza i 42 dana ratarske kulture. Ne koristiti za zadnje tretiranje u kombinaciji s ditiokarbamatima radi produljenja perzistentnosti. Na jagodičastom voću namijenjenom za industrijsku preradu ne koristiti u razdoblju od cvatnje do berbe. Karenca za Cosavet DF- 21 dan za jagodu, ogrozd i ribiz. Radna Karenca: 1 dan.

\subsection{Fungicidi na bazi kalija}

(engl. Potassium fungicides)

\subsubsection{Kalijevi fosfonati}

Fosfonična kiselina iz kalijevog fosfonata koju biljka usvaja djeluje na način da ojačava obrambene mehanizme biljke. Koristi za suzbijanje uzročnika plamenjače na vinovoj lozi.

\subsubsection{Kalijev hidrogen karbonat}

Kontaktni fungicid koji djeluje na način da isušuje hife i spore gljiva. Dozvoljen je u ekološkoj poljoprivredi. Koristi za suzbijanje uzročnika pepelnice na vinovoj lozi.

Najveća količina sredstva koja se smije primjeniti godišnje je $63 \mathrm{~kg} / \mathrm{ha}$.

\subsection{Mikrobiološki fungicidi/inokulanti}

(engl. Microbial fungicides)

Aktivni sastojci su živi organizmi, npr. bakterije. Tijekom rasta i razvoja nemaju negativan utjecaj na kulturu, već samo na druge organizme štetne za kulturu.

\subsubsection{Pseudomonas sp.}

Proradix je mikrobiološki fungicid na osnovi bakterije Pseudomonas sp. (soj 13134). Bakterija naseljava korijen i rizosferu te spriječava razvoj patogena u tlu.

\subsubsection{Pepino mosaic virus}

PMV-01 je sredstvo koje sadrži blagi oblik Pepino mozaik virusa. Primjenom se postiže unakrsna zaštita rajčice od Pepino mozaik virusa, soj CH2. Primjenjuje se što prije nakon sadnje, a prije cvatnje. Bilje ne smiju biti zaražene s PMV u vrijeme tretiranja. 


\section{INSEKTICIDI}

\subsection{Karbamati}

(engl. Carbamates)

Karbamati djeluju na živčani sustav insekata imaju isti mehanizam djelovanja kao i insekticidi iz grupe organofosfata, odnosno i onisu inhibitori enzima acetilkolin esteraze (AChE), na temelju čega su razvrstani u IRAC grupu 1A. Zbog inhibicije ovog enzima u organizmu insekata dolazi do nagomilavanja acetilkolina, koji je neophodan za transmisiju živčanih impulsa, što dovodi do paralize različitih organa, posebno mišića, a potom i uginuća tretiranih insekata.

Acetilkolin je kemijski posrednik u stanicama živčanog sustava (parasimpatomimetik) i kod insekata je neophodan za transmisiju živčanih impulsa. Receptori acetilkolina u organizmu insekta su: stanice koje inerviraju postsinaptičke receptore (srce, žlijezde i glatka muskulatura), kao i stanice koje inerviraju presinaptičke receptore i somatski motorni živci (ganglije, vlakna skeletnih mišića i nadbubrežna žlijezda).

Fiziološka uloga acetilkolin esteraze je u katalitičkom djelovanju, odnosno u hidrolizi acetilkolina na kolinergičnim sinapsama u organizmu insekta. Pri inhibiciji acetilkolinesteraze dolazi do: muskarinskog djelovanja (zbog stimulacije parasimpatikusa); nikotinskog djelovanja (stimulacija, a zatim paraliza vegetativnih ganglija i skeletnih mišića), kao i stimulativnog, a zatim depresivnog djelovanja na pojedine dijelove centralnog živčanog sustava insekata, pri čemu manja inaktivacija acetilkolin esteraze kod insekata dovodi do hiperaktivnih funkcija, ovisnih od povećanja koncentracije acetilkolina, dok znatnije povećanje acetilkolina kod njih uzrokuje paralizu različitih organa.

Svi karbamati su opasna do vrlo opasna sredstva. Neki od njih imaju kontaktno, a neki sistemično djelovanje, zbog čega se neki koriste za suzbijanje velikog broja štetočinja, dok su neki izraziti aficidi (sredstva za suzbijanje lisnih uši). Zbog svojstva da metaboliziraju u toksičnije spojeve od početne djelotvorne tvari, nekima je vrlo ograničena upotreba i zabranjeni su u nekim kulturama (npr. u povrću).

Prema preporuci IRAC (Insecticide Resistance Action Committee), da bi se izbjegla opasnost od pojave unakrsne rezistencije, insekticidi na bazi aktivnih tvari koje pripadaju IRAC grupama 1A (karbamati) i 1B (organofosfati) se mogu naizmjenično koristiti, odnosno rotirati, samo u slučaju da nema drugih alternativa i kada je sa sigurnošću poznato da mehanizmi unakrsne rezistencije nisu utvrđeni kod populacije insekata koja će biti tretirana.

\subsubsection{Metiokarb}

Djeluje rezidualno jer metabolizira u sulfoksid i sulfon.

$\mathrm{LD}_{50}$ - 100. S.O. - II (ispod $40 \%$ - III). 


\subsection{1.a) Za tretiranje tla i/ili sjemena}

Tretiranjem sjemena štiti biljku od žičnjaka ili rovca, a sjeme i od ptica repelentnim djelovanjem.

Karenca - OVP.

\subsubsection{Pirimikarb}

Sistemični selektivni aficid za suzbijanje i najotpornijih vrsta lisnih ušiju. Slabo toksičan za pčele i korisne insekte.

$\mathrm{LD}_{50}$ - 147. S.O. - II, odnosno III (do 50\% djelatne tvari).

\subsection{Organofosfati}

(engl. Organophosphates)

Organofosfati djeluju na živčani sustav insekata iimaju isti mehanizam djelovanja kao i insekticidi iz grupe karbamata, odnosno i onisu inhibitori enzima acetilkolin esteraze (AChE), na temelju čega su razvrstani u IRAC grupu 1B. Zbog inhibicije ovog enzima u organizmu insekata dolazi do nagomilavanja acetilkolina, koji je neophodan za transmisiju živčanih impulsa, što dovodi do paralize različitih organa, posebno mišića, a potom i uginuća tretiranih insekata.

Acetilkolin je kemijski posrednik u stanicama živčanog sustava (parasimpatomimetik) i kod insekata je neophodan za transmisiju živčanih impulsa. Receptori acetilkolina u organizmu insekta su: stanice koje inerviraju postsinaptičke receptore (srce, žlijezde i glatka muskulatura), kao i stanice koje inerviraju presinaptičke receptore i somatski motorni živci (ganglije, vlakna skeletnih mišića i nadbubrežna žlijezda).

Fiziološka uloga acetilkolin esteraze je u katalitičkom djelovanju, odnosno u hidrolizi acetilkolina na kolinergičnim sinapsama u organizmu insekta. Pri inhibiciji acetilkolinesteraze dolazi do: muskarinskog djelovanja (zbog stimulacije parasimpatikusa); nikotinskog djelovanja (stimulacija, a zatim paraliza vegetativnih ganglija i skeletnih mišića), kao i stimulativnog, a zatim depresivnog djelovanja na pojedine dijelove centralnog živčanog sustava insekata, pri čemu manja inaktivacija acetilkolin esteraze kod insekata dovodi do hiperaktivnih funkcija, ovisnih od povećanju koncentracije acetilkolina, dok znatnije povećanje acetilkolina kod njih uzrokuje paralizu različitih organa.

Prema načinu djelovanja organofosfati su podijeljeni u dvije temeljne skupine: nesistemici koji djeluju kontaktno na površini tretiranog objekta (biljke) i sistemici koji prodiru u biljku koja ih prenosi kolanjem sokova svojim provodnim snopovima. Sistemici djeluju želučano (sisanjem sokova), a neki imaju i kontaktno djelovanje.

Prema preporuci IRAC (Insecticide Resistance Action Committee), da bi se izbjegla opasnost od pojave unakrsne rezistencije, insekticidi na bazi aktivnih tvari koje pripadaju IRAC grupama 1A (karbamati) i 1B (organofosfati) se mogu naizmjenično koristiti, odnosno rotirati, samo u slučaju da nema drugih alternativa i kada je sa sigurnošću poznato da mehanizmi unakrsne rezistencije nisu utvrđeni kod populacije insekata koja će biti tretirana. 


\subsubsection{Dimetoat}

Sistemik. Uz sistemično, ima izraženo i kontaktno djelovanje, pa se koristi za suzbijanje insekata koji sišu (lisne i štitaste uši, stjenice, tripsi itd.) i grizu (maslinova mušica i moljac, trešnjina muha, šljivine osice, razne gusjenice, voćna muha, jabučni savijači i drugi). Djeluje i na grinje. Namijenjen je za suzbijanje štetnih insekata u voćarstvu, duhanu, repi i kupusnjačama. $\mathrm{Ne}$ tretirati biljke ovim insekticidom u vrijeme cvatnje!

LD ${ }_{50}$ oko 150. S.O. - III (1- 40\% djelatne tvari). Prodire kroz neoštećenu kožu.

\subsubsection{Klorpirifos}

Nesistemik. Kontaktni, želučani i dišni insekticid. Hlapljiv i čvrsto se veže na čestice tla. Koristi se za suzbijanje štetnika voćaka (lisne i krvave uši, lisne buhe, savijača, cvjetara i drugih), šećerne repe, uljane repice, duhana, kukuruza, pšenice, (sovice, metlice, lisne uši, stjenice, buhači i drugi). Učinkovit i na gubara, kao i na štetnike u tlu. Ne smije se koristiti u: peršinu, celeru, rotkvici, mladoj mrkvi, radiću, salati, mladom krumpiru i mladom luku.

$\mathrm{LD}_{50}$ - 135. S.O. - II (više od 50\% djelatne tvari) ili III (od 2-50\% djelatne tvari). Može biti fitotoksičan za vinovu lozu, krastavce, salatu, ruže, azaleje i kamelije.

\subsection{2.a) Za tretiranje tla}

Dozvoljen je i za suzbijanje kukuruzne zlatice. Obavezno se mora unijeti u tlo!

\subsubsection{Pirimifos-metil}

Nesistemik. Kontaktni, želučani i volatilni insekticid, izraženog brzog i fumigantnog djelovanja. Koristi se protiv štitastih i lisnih ušiju, tripsa, lisnih buha, voćne mušice i nekih drugih štetnika. Djeluje i na grinje. Učinkovit je i na štetnike u skladištima.

$\mathrm{LD}_{50}$ oko 2000. S.O. - III.

\subsection{3. a) Za dezinsekciju žitarica}

Koristi se za tretiranje uskladištenih proizvoda u silosima i podnim skladištima za vrijeme transportiranja na transporteru. Ne djeluje na Rizopertu.

\subsubsection{Fosmet}

Nesistemik, djeluje kontaktno, ali i gutanjem i udisanjem, ometa prijenos živčanih impulsa inhibicijom kolinesteraze. Namijenjen je za suzbijanje lisnih ušiju, grinja, voćnih muha na voću, ukrasnom bilju i vinovoj lozi.

$$
\mathrm{LD}_{50}-113 \text { do } 160 \text {. }
$$

\subsection{Antranilni diamidi}

Nova su grupa insekticida iz koje su poznate tri djelatne tvari: klorantraniliprol, ciantraniliprol i flubendiamid. Prema IRAC klasifikaciji zajednički specifični mehanizam djelovanja je modifikacija receptora ryanodina u mišićnim stanicama i razvrstane su u skupinu 28 . Ne radi se o nervnim otrovima nego o insekticidima koji djeluju u mišićnom tkivu tako što potiču gubitak iona kalcija iz stanica mišićnog tkiva što dovodi do paralize mišića i smrti. 


\subsubsection{Klorantraniliprol}

Pripada novoj kemijskoj skupini selektivnih antranilnih diamidnih insekticida s novim načinom djelovanja. Djeluje tako da aktivira receptore ryanodina u mišićnim stanicama. Spremljeni ioni kalcija oslobađaju se iz sarkoendoplazmatskog retikuluma organele koja u mišićnim stanicama služi čuvanju kalcija. Posljedica je gubitak kalcija koji dovodi do paralize i smrti kukca. Kontaktno je želučani insekticid koji se odlikuje i translaminarnim te sistemičnim djelovanjem. Na kukce djeluje ovicidno i larvicidno. U tlu je srednje mobilan, a razgrađuje se aerobnom razgradnjom. Poluraspad je 204 dana. Pokazuje slab potencijal za biokoncentraciju. Za ptice je malo toksičan, za ribe srednje, a za vodene beskralježnjake je visoko toksičan. Zbog selektivnosti koju pokazuje na korisne člankonošce, smatra se pogodan za primjenu u integriranoj zaštiti bilja. Malo je opasan za pčele, oralni $\mathrm{LD}_{50}$ je $104 \mu \mathrm{g} /$ pčeli, kontaktni $\mathrm{LD}_{50}$ je $4 \mu \mathrm{g} / \mathrm{pčeli}$.

$\mathrm{LD}_{50}$ oralni I dermalni Iznad $5000 \mathrm{mg} / \mathrm{kg}$, LC50 iznad $5.1 \mathrm{mg} / \mathrm{L} . \mathrm{O}=\mathrm{III}$.

Karenca- 7 dana za kukuruz i kukuruz šećerac; 14 dana za jabuku, krušku, breskvu, nektarinu, šljivu I krumpir; 30 dana za vinovu lozu.

\subsection{Sintetski piretroidi}

(engl. Pyrethroids)

Insekticidi iz ove grupe djeluju na živčani sustav insekata inhibirajući protok natrijevih iona kroz membrane živčanih stanica što dovodi do poremećaja u protoku živčanih impulsa kroz natrijeve kanale, zbog čega nastaje uginuće tretiranih insekata. Na osnovu navedenog mehanizma djelovanja ovi inekticidi su razvrstani u IRAC grupu 3A.

Sintetski piretroidi su nesistemični insekticidi vrlo širokog spektra djelovanja, s brzim kontaktnim i želučanim djelovanjem. Glavno pozitivno svojstvo je njihova visoka insekticidnost koja omogućava korištenje u vrlo niskim dozama, odnosno koncentracijama. Zbog ove osobine njihova upotreba smanjuje opasnost od onečišćenja okoliša, a dobro djeluju i pri nižim temperaturama. Neki od njih suzbijaju i voćnog crvenog pauka i koprivinu grinju. Njihova izvjesna repelentnost smanjuje opasnost za pčele. Svi pripadaju opasnim sredstvima.

Kao negativna svojstva sintetskih piretroida ističe se mogućnost brze pojave rezistentnosti, kao i vrlo širok spektar djelovanja zbog čega često izazivaju i uništenje korisnih insekata. Ne preporuča se njihova česta upotreba te ih treba koristiti naizmjenično s drugim grupama insekticida kako bi se usporila pojava rezistentnosti. Smiju se koristiti najviše dva puta tijekom vegetacije. Vrlo su otrovni za ribe i pčele.

\subsubsection{Alfa-cipermetrin}

Kontaktni i želučani insekticid širokog spektra. Suzbija ličinke i odrasle oblike štetnika. Dobrog početnog i dugotrajnog djelovanja. Djelotvoran u vrlo malim koncentracijama. U zaštiti kupusnjača dodati okvašivač.

$\mathrm{LD}_{50}$ - 64. S.O. - III. Manje opasan za pčele. 


\subsubsection{Cipermetrin}

Cipermetrin je smjesa svih izomera. Koristi se za suzbijanje jabučnog i breskvinog savijača, kruškine buhe, lisnih ušiju, lisnih i sovica pozemljuša, repičinog sjajnika, štitastog moljca i drugih.

LD $_{50}$ - 82-250. S.O. iznad 20\% djelatne tvari - II, inače III.

Pripravak: Chromorel-D, Kalinorel D EC, Nurelle D, Direkt, Fastac 10 EC, Storanet.

\subsubsection{Deltametrin}

Kontaktni i želučani insekticid širokog spektra djelovanja, učinkovit u vrlo niskim dozama. Ima dugo rezidualno djelovanje. Koristi se za suzbijanje jabučnog, breskvinog i šljivinog savijača, kruškine buhe, grozdovih moljaca, lisnih ušiju, lisnih sovica, tripsa duhana, repičinog sjajnika, štitastog moljca i drugih. Manje opasan za pčele.

$\mathrm{LD}_{50}$ - 33-130. S.O. - II, ispod 2,5\% III.

\subsection{3. a) Za dezinsekciju}

Za preventivno suzbijanje štetnika uskladištenih proizvoda. Količina 0,25 g d.t./t osigurava zaštitu 6 mjeseci, a 0,5 g d.t./t 12 mjeseci.

\subsubsection{Esfenvalerat}

Insekticid brzog i dugotrajnog djelovanja. Djeluje protiv jabučnog savijača, lisnih minera i ušiju, lisnih sovica, repičine ose listarice i drugih.

$\mathrm{LD}_{50}$ - 75-400. S.O. - II, ispod 5\% - III.

\subsubsection{Gama i lambda cihalotrin}

Piretroid četvrte generacije, širokog spektra sa CF3 -klor vinilnom grupom. Suzbija štetnike u voćarstvu, na vinovoj lozi, šećernoj repi i uljanoj repici, kao i krumpirovu zlaticu, žitnog balca i druge. U šumama suzbija hrastovog savijača, suznike i mrazovce.

$\mathrm{LD}_{50}$ - 923. S.O. - II, ispod 5\% - III.

\subsubsection{Tau-fluvalinat}

Namijenjen je za suzbijanje raznih vrsta biljnih ušiju na jabuci, ruži i šećernoj repi. Bezopasan je za pčele.

$\mathrm{LD}_{50}$ - 260-3000. S.O. - III.

\subsection{7 . Teflutrin}

Najtopljiviji i najhlapljiviji piretroid III generacije, prikladan za suzbijanje štetnika u tlu na pšenici, šećernoj repi, kukuruzu i suncokretu.

$\mathrm{LD}_{50}$ - 25. S.O. - II, do $20 \%$ - III. K - OVP.

\subsection{7. a) Za tretiranje tla i/ili sjemena}




\subsection{Neonikotinoidi}

(engl. Neonicotinoids)

Insekticidi iz ove grupe djeluju na živčani sustav insekata uzrokujući ireverzibilnu blokadu postsinaptičkih nikotinergičnih acetilholin receptora (nAChR), što dovodi do održavanja stalno otvorenih Na-kanala i stimulacije električnih impulsa, čime se ometa prijenos podražaja u živčanom sustavu štetnih insekata i uzrokuje blokiranje njihovih osnovnih funkcija. Na osnovu navedenog mehanizma djelovanja, koji se razlikuje od načina djelovanja insekticida iz skupine karbamata, organofosfata i piretroida, insekticidi iz ove grupe su razvrstani u IRAC grupu 4A. Odlikuju se izrazitim sistemičnim, kao i kontaktnim i digestivnim djelovanjem.

Koriste se za suzbijanje velikog broja insekata (lisnihuši, tripsa, krumpirove zlatice, bijele mušice i dr.). Koriste se i protiv zemljišnih insekata, no nemaju efikasnost na nematode i grinje. Pripadaju opasnim sredstvima te su svrstani u III. skupinu otrova. Da bi se umanjila mogućnost pojave unakrsne rezistentnosti treba izbjegavati alternativno korištenje insekticida iz grupe neonikotinoida koji imaju isti mehanizam djelovanja, odnosno preparata na bazi acetamiprida, imidakloprida, tialkoprida i tiametoksama.

\subsubsection{Acetamiprid}

Kontaktnog, želučanog i sistemičnog djelovanja. Učinkovit protiv velikog broja različitih insekata s usnim ustrojem za grizenje i sisanje, kao i raznih gusjenica iz reda Lepidoptera. U nas dopušten za uporabu u šećernoj repi, krumpiru, duhanu, breskvama, jabukama, krastavcima, paprici, rajčici i ukrasnom bilju. Djelatna tvar u sredstvu ometa prijenos podražaja u živčanom sustavu štetnih organizama na način koji se razlikuje od insekticida iz skupine organofosfornih spojeva, karbamata i piretroida. Izrazite sistemičnosti, brzog i snažnog, ali umjerenog rezidualnog djelovanja.

$$
\mathrm{LD}_{50} \text { - 146-217. S.O. - III. }
$$

\subsubsection{Imidakloprid}

Izrazito sistemični insekticid, dopušten za suzbijanje mnogih kukaca koji sišu i nekih koji grizu, uključujući mnoge vektore viroza. Djeluje kontaktno i želučano. U spektru obuhvaća: lisne uši, duhanovog resičara, štitaste moljce, lisne minere agruma, krumpirovu zlaticu te štetnike u tlu. Može se primijeniti i sustavom za navodnjavanje. Perzistentan je u tlu pa se iste godine ne smije uzgajati lisnato povrće na tretiranoj površini.

$$
\mathrm{LD}_{50} \text { - 450. S.O. - III. }
$$

\subsection{2.a) Za tretiranje sjemena, gomolja i lučica}

Služi za tretiranje sjemena šećerne repe, suncokreta, uljane repice i kukuruza protiv štetnika u tlu i nekih nadzemnih štetnika. Ima dozvolu i za tretiranje gomolja za sadnju krumpira protiv krumpirove zlatice i lisnih ušiju uz djelotvornost kod ranog napada žičnjaka.

U godini primjene ne smije se na tretiranoj površini uzgajati lisnato povrće. Nakon tretiranja gomolja nije dopuštena folijarna primjena pripravaka na istoj osnovi. 


\subsubsection{Klotianidin}

Najperzistentniji sistemični neonikotionid. Za suzbijanje podzemnih i nadzemnih štetnika kukuruza, šećerne repe i suncokreta.

$\mathrm{LD}_{50}$ - 500. S.O. - III.

\subsubsection{Tiakloprid}

Ometa prijenos podražaja u živčanom sustavu. Djeluje kontaktno i želučano. Suzbija lisne uši na voćkama, rajčici, paprici, krastavcima, lubenicama, ružama, jabučnu osicu, neke minere, krumpirovu zlaticu itd. Visoko učinkovit na niskim i visokim temperaturama. Vrlo brzo ulazi u tkivo biljke. Nije opasan za oprašivače te se može primijeniti i u cvatnji.

$\mathrm{LD}_{50}$ - 444. S.O. - III.

\subsection{4.a) Za tretiranje sjemena, gomolja i lučica}

\subsubsection{Tiametoksam}

Izraziti sistemik, umjerene perzistentnosti, dopušten za suzbijanje mnogih kukaca koji sišu i nekih koji grizu, uključujući mnoge vektore viroza.

$\mathrm{LD}_{50}$ - 1563. S.O. - III.

\subsection{5.a) Za tretiranje sjemena}

Primjenjuje se protiv štetnika u tlu i nekih nadzemnih štetnika tretiranjem sjemena.

\subsection{Avermektini}

(engl. Avermectins)

Insekticidi iz ove grupe djeluju na živčani i mišićni sustav insekata aktiviranjem kloridnih kanala, uzrokujući antagonističko djelovanje na $\gamma$-amino maslačnu kiselinu (GABA), čime se ometa prijenos podražaja u živčanom sustavu štetnih insekata i uzrokuje blokiranje njihovih mišićnih funkcija, na temelju čega su oni razvrstani u IRAC grupu 6. Avermektini su grupa makrocikličnih laktona koji su dobiveni u procesu fermentacije iz zemljišne aktinomicete Streptomyces avermitilis, koja je prvi put izolirana iz uzorka tla sa jednog japanskog golf terena.

\subsubsection{Abamektin}

Insekticid i akaricid kontaktnog i želučanog djelovanja. U biljci se kreće translaminarno. Prirodni proizvod aktinomicete Streptomyces avermitilis. Visoko toksičan za akvatične organizme i pčele. Odlično djeluje na običnu kruškinu buhu i crvenog voćnog pauka. Štetnici koji dođu u kontakt s ovom djelatnom tvari ili je unesu hranom u organizam postaju nepokretni i za 2-4 dana uginu. Za to vrijeme se ne hrane i ne uzrokuju štete. Prikladan u integriranoj proizvodnji voća jer vrlo slabo utječe na populaciju korisnih insekata u nasadima voća. Pod utjecajem svjetlosti djelatna tvar se na listu vrlo brzo razgradi tako da ima samo kratkotrajno kontaktno djelovanje na korisne vrste. 
Najbolji rezultati u primjeni ovog pripravka dobiju se ranijom primjenom, početkom vegetacije i razvoja populacije štetnika.

$$
\mathrm{LD}_{50}-891 \mathrm{mg} / \mathrm{kg} \text {. S.O. - III. }
$$

\subsubsection{Emamektin benzoat}

Insekticid sa kontaktnim i želučanim djelovanjem koji pokazuje odlično translaminarno kretanje u listovima. Djeluje larvicidno što znači da suzbija sve stadije gusjenica, a poglavito prve stadije neposredno poslije izlaska iz jajašaca (to je i najbolje vrijeme primjene). Kada insekt dođe u kontakt s emamektin benzoatom, dolazi do paralize i trenutnog prestanka ishrane, nakon čega ugine u roku od 2 do 4 dana. Preparat se brzo razlaže na svjetlosti, posebno pri jačem UV zračenju, pa je njegova rezidualna kontaktna aktivnost zanemarljiva. Da bi se povećalo kontaktno djelovanje preporučuje se primjena preparata u večernjim satima. Stupanj efikasnosti preparata se povećava dodavanjem mineralnog ulja, u koncentraciji 0,25\%.

$\mathrm{LD}_{50}$ - >2000 mg/kg. S.O. - III.

\subsection{Milbemicini}

(engl. Milbemycins)

Kao i avermektini spadaju u IRAC grupu 6. Prvi puta su izolirani 1972 iz Streptomyces hygroscopicus.

\subsubsection{Milbemektin}

Mješavina je milbemicina A3 i milbemicina A4 u omjeru 30:70. Primjenjuje se kod pojave prvih pokretnih stadija.

$\mathrm{LD}_{50}-5200$.

\subsection{Spinosini}

(engl. Spinosyns)

Insekticidi iz ove grupe djeluju na živčani sustav insekatauzrokujući blokadu nikotinergičnih acetilkolin receptor (nAChR) alosteričnih aktivatora, čime se ometa prijenos podražaja u živčanom sustavu štetnih insekata i uzrokuje blokiranje njihovih osnovnih funkcija, na temelju čega su oni razvrstani u IRAC grupu 5. Koriste se za suzbijanje velikog broja insekata u krumpiru, vinovoj lozi, jabukama, paprici, krastavcima, rajčici i gerberima, a prikladni su i za primjenu u zatvorenim prostorima.

\subsubsection{Spinosad}

Insekticid sa sistemičnim, kontaktnim i želučanim djelovanjem. Mješavina tvorevina bakterije Saccharopolyspora spinosa, spinosada A i spinosada D. Primjenjuje se za suzbijanje većeg broja različitih insekata u krumpiru, vinovoj lozi, jabukama, paprici, krastavcima, rajčici i gerberima. Prikladan je i za primjenu u zatvorenim prostorima kod proizvodnje krastavaca, paprike, rajčice $i$ gerbera.

$$
\text { LD }_{50} \text { - 3783-5000. S.O. - III. }
$$




\subsubsection{Spinetoram}

Mješavina tvorevina bakterije Saccharopolyspora spinosa. Analog je spinosada. Koristi se u vinovoj lozi za suzbijanje štetnih leptira, te mušica i tripsa.

$\mathrm{LD}_{50}>5000, \mathrm{~K}-7$ dana vinova loza. Dozvoljeno jedno tretiranje godišnje.

\subsection{Pimetrozin (Piridini)}

(engl. Pymetrozine)

Insekticidi iz ove grupe se odlikuju selektivnim djelovanjem na prekid (blokiranje) procesa ishrane insekata iz reda Homoptera, što dovodi do njihovog uginuća koje nastupa u roku od nekoliko dana. Za to vrijeme, insekt se normalno kreće, ali se ne hrani, čime se spriječava njegova uloga kao vektora pojedinih virusnih oboljenja. Na osnovu navedenog mehanizma djelovanja ova grupa insekticida je razvrstana u IRAC grupu 9B.

Za sada iz ove grupe dozvolu ima samo jedna djelatna tvar - pimetrozin.

\subsubsection{Pimetrozin}

Insekticid sa sistemičnim, kontaktnim i želučanim selektivnim djelovanjem namijenjen za suzbijanje lisnih uši (Aphididae) i štitastih moljaca (Aleyrodidae) na povrću, ukrasnom bilju i hmelju. Jedan sat poslije tretiranja dolazi do prekida ishrane kod svih vrsta lisnih ušiju i štitastih moljaca, nakon čega se oni nastavljaju kretati, ali se više ne hrane. Uginuće štetnika nastaje od gladi nekoliko dana poslije primjene pripravka u zavisnosti od vrste uši koja se suzbija. Prestanak ishrane štetnog insekta na uzgojenoj biljci, odmah po primjeni preparata, spriječava prenošenje opasnih virusnih bolesti čiji su ovi štetnici vektori (virus mozaika krastavca, špinata i salate, virus pjegavosti kupusa, virus žute patuljavosti crnog luka, itd.).

Aktivna tvar pimetrozin prodire u biljno tkivo i sistemično se, kolanjem sokova u biljci, raspodjeljuje čak i u novi rast biljke. Translaminarno djelovanje pripravka CHESS $50 \mathrm{WG}$ osigurava suzbijanje i skrivenih štetnika na biljci.

$$
\text { LD }_{50} \text { - 2000-5000. S.O. - III. }
$$

\subsection{Derivati benzoiluree (Regulatori razvoja insekata)}

\section{(engl. Benzoylureas)}

Insekticidi iz ove grupe inhibiraju biosintezu hitina, tipa 0, blokiranjem aktivnosti enzima hitinaze kod osjetljivih insekata, zbog čega kod njih dolazi do spriječavanja presvlačenja ličinki ili pak djeluju poput juvenilnog hormona, ometajući tako razvoj odraslih insekata. Na osnovu navedenog mehanizma djelovanja ova grupa insekticida je razvrstana u IRAC grupu 15. Dakle, insekticidi iz ove grupe kukce ne ubijaju izravno već kod njih ometaju i onemogućavaju razvoj određenih stadija, zbog čega se nazivaju i regulatori rasta insekata. Većina djeluje samo na ličinke, a neki donekle i na jaja. Neznatno su opasni do opasni. Selektivni su, pa djeluju na manje skupine štetnika i samo na mali broj korisnih kukaca, zbog čega se smatraju ekološki prihvatljivim i prikladnim za sustav integrirane zaštite bilja. 


\subsubsection{Diflubenzuron}

Inhibitor enzima hitinaze i stvaranja hitina neophodnog za presvlačenje ličinki. Perzistentan u okolini.

$\mathrm{LD}_{50}$ - 2100. S.O. - III (iznad 5\%).

\subsubsection{Lufenuron}

Inhibitor enzima hitinaze. Koristi se za suzbijanje ličinki krumpirove zlatice, jabučnog savijača, savijača kožice ploda i grozdovih moljaca. Preparati koji ometaju razvoj insekata imaju vrlo dugo djelovanje. Budući da djeluje na razvoj ličinki, važna je pravodobna primjena. Bolje je primijeniti ga malo ranije nego prekasno.

$\mathrm{LD}_{50}$ - 3000. S.O. - II.

\subsubsection{Teflubenzuron}

Inhibitor enzima hitinaze, rezidualnog i kontaktnog djelovanja. Neznatno opasan. $\mathrm{LD}_{50}$ - 5000. S.O. - III.

\subsection{Diacilhidrazini}

(engl.Diacylhydrazines)

Insekticidi iz ove grupe ometaju parenje i metamorfozu kod osjetljivih insekata, na temelju čega su razvrstani u IRAC grupu 18. Djeluju kao agonisti ekdisona kod leptira jer se vežu na njihov receptorski protein čime ubrzavaju (induciraju) prerano presvlačenje ličinki uz hipertrofiju njihovih epidermalnih stanica. Imaju potpuno drugačiji način djelovanja na insekte u odnosu na inhibitore sinteze hitina i regulatore razvoja insekata.

Selektivni su, pa djeluju na manje skupine štetnika i samo na mali broj korisnih kukaca, zbog čega se smatraju ekološki prihvatljivim i prikladnim za sustav integrirane zaštite bilja.

\subsubsection{Metoksifenozid}

Agonist ekdisona leptira jer se veže na njihov receptorski protein. Ubrzava presvlačenje uz hipertrofiju epidermalnih stanica. Pogodan je za integriranu zaštitu.

$\mathrm{LD}_{50}$ - 5000. S.O. - III.

\subsubsection{Tebufenozid}

Ova djelatna tvar kao i metoksifenozid ima potpuno drugačiji način djelovanja na insekte u odnosu na inhibitore sinteze hitina i regulatore razvoja insekata. Ubrzava (inducira) prerano presvlačenje uz hipertrofiju epidermalnih stanica. Dozvoljen za suzbijanje jabučnog savijača, grozdovih moljaca, zlatokraja, kukavičjeg suznika i štetnih gusjenica u šumama. Djeluje na sve razvojne stadije ličinke. Pogodan za integriranu zaštitu bilja.

LD 50 - 5000. S.O. - III. K - 21 dan jabuke i kruške; 28 dana vinova loza. Najviše dvije primjene godišnje 


\subsection{Keto-enoli}

Keto-enoli su inhibitori acetil-CoA karboksilaze. U ovu skupinu ubrajamo tri djelatne tvari: spirodiklofen, spiromesifen i spirotetramat. U Hrvatskoj dozvolu imaju dva pripravka na bazi spirodiklofena i spirotetramata.

\subsubsection{Spirodiklofen}

Pripravak: Envidor SC 240

\subsubsection{Spirotetramat}

Insekticid dugotrajnog djelovanja i širokog spektra. Sistemični je insekticid (dvosmjerna sistemičnost) te se koristi za suzbijanje kukaca koji sišu biljne sokove. Siguran je za korisne organizme te ekološki prihvatljiv.

$\mathrm{LD}_{50}$ - >2000. S.O. - III.

\subsection{Insekticidi različitog kemijskog podrijetla}

\subsubsection{Fenoksikarb}

Fenoksikarb djeluje kao analog juvenilnog hormona, na temelju čega je razvrstan u IRAC grupu 7B. Ima ovicidno i larvicidno djelovanje. Zbog selektivnosti je prikladan u integriranoj zaštiti.

$\mathrm{LD}_{50}$ - 5000. S.O. - III.

\subsubsection{Flonikamid}

Flonikamid djeluje selektivnim blokiranjem ishrane kod insekata iz reda Homoptera, na temelju čega je razvrstan u IRAC grupu 9C. Koristi se kao selektivni kontaktnosistemični aficid u nasadima jabuka, šljiva i breskve. Opasan. Nema unakrsne rezistetnosti s neonikotinoidima i piretroidima.

$\mathrm{LD}_{50}$ - 884. S.O. - III.

\subsubsection{Fostiazat}

Rezidualni sistemični insekto-nematocid. U krumpiru se koristi uz obaveznu inkorporaciju u tlo $(10-15 \mathrm{~cm})$.

$\mathrm{LD}_{50}-57$.

\subsubsection{Indoksakarb}

Indoksakarb je selektivni insekticid koji djeluje na živčani sustav insekata blokiranjem Nakanala što dovodi do poremećaja u protoku živčanih impulsa, zbog čega nastaje uginuće tretiranih insekata, na temelju čega je razvrstan u IRAC grupu 22A. Indoksakarb je naziv za (S)-stereoizomer jer je samo on insekticidan.

$\mathrm{LD}_{50}$ - 751. S.O. - III. 


\subsubsection{Metaflumizon}

Metaflumizon djeluje na živčani sustav insekata blokiranjem Na-kanala što dovodi do poremećaja u protoku živčanih impulsa, zbog čega nastaje uginuće tretiranih insekata, na temelju čega je razvrstan u IRAC grupu 22B. Pripada posve novoj grupi insekticida. Zbog specifičnog načina djelovanja dosada se nije pojavila unakrsna rezistentnost s ostalim grupama insekticida. Koristi se za suzbijanje štetnika u krumpiru (Lepidoptera, Coleoptera, Hemiptera, Hymenoptera). Ima povoljan toksikološki i ekotoksikološki profil.

$\mathrm{LD}_{50}>5$ 000. S.O. - III.

\subsection{Mineralna ulja}

Koriste se za prskanje voćaka, agruma, maslina, vinove loze i ukrasnog bilja u vrijeme mirovanja vegetacije ili prije cvatnje. Insekticidno djeluje na veliki broj štetnika - lisne uši, crvene pauke, štitaste uši itd.

\subsubsection{Parafinsko ulje}

Djeluju na štitaste uši, zimska jaja crvenih pauka, jaja lisnih uši i mrazovca, a primijenjeni tijekom vegetacije djeluju i na štitaste i lisne uši. Rabi se u nasadima: jabuke, kruške, šljiva, maslina, agruma, vinove loze, smokava i oleandra. Smanjuje zarazu virusima na sjemenskom krumpiru. K - 42 (Bijelo ulje, Mineralno svijetlo ulje). Najviše 2 tretiranja u sezoni.

\subsubsection{Kombinirani pripravci bakra i mineralnog ulja}

Upotrebljavaju se kao insekto-akaro-fungicidi za prskanje voćaka i vinove loze u vrijeme mirovanja vegetacije. Suzbijaju uzročnike bolesti voćaka koji se suzbijaju "plavim" prskanjem; štitaste uši, jaja lisnih uši i crvenog pauka, te neke druge štetnike koji prezimljuju na voćkama i vinovoj lozi.

S.O. - III.

\subsection{Pripravci za fumigaciju}

Djeluju u plinovitom stanju iako se kao pripravci nalaze u tekućem ili čvrstom obliku. Koriste se za suzbijanje skladišnih štetnika na žitaricama i drugim plodovima te nekim drugim namirnicama, kao i za suzbijanje karantenskih i drugih štetnika na voćnim sadnicama, voću i drugim poljoprivrednim proizvodima. Neki se koriste i za suzbijanje štetnih glodavaca u polju, štetnika u staklenicima i nekih nametnika u tlu. Glede njihove velike otrovnosti i specifičnog načina primjene potrebno je da s njima radi, za taj posao, osposobljeno i ovlašteno stručno osoblje. Ekspozicija propisana. Zbog zaštite ozonskog omotača primjena metilbromida s klorpikrinom dopuštena je samo za suzbijanje borove nematode i strizibuba na drvenoj ambalaži. Metilbromid, aluminijev fosfid i magnezijev fosfid su uvršteni u I skupinu otrova. Standardna masa peleta je $0,6 \mathrm{~g}$, a tableta i kuglica $3 \mathrm{~g}$. Primjena metilbromida bila je dopuštena do kraja 2005. godine. 
T - za metilbromid: ukupni anorganski bromidi (računano na brom) 400 začini; 50 žitarice i proizvodi, povrće, orasi, uljarice, sirova kava, čajevi, osušeno voće i čips; 30 agrumi; 20 svježe voće i mlijeko; 5 ostale namirnice biljnog podrijetla.

ZABRANJENA JE FUMIGACIJA TIJEKOM KOPNENOG I ZRAČNOG TRANSPORTA!

\subsubsection{Aluminijev fosfid}

Karenca -2 dana brodska štiva, uskladišteni zrnati poljoprivredni proizvodi; 5 dana uskladišteni duhan.

\subsubsection{Magnezijev fosfid}

Karenca - 5 dana uskladišteni duhan; 2 dana uskladišteni zrnati poljoprivredni proizvodi, prazno skladište, mlinovi, brodska štiva (Detia Degesch ploče). 5 dana uskladišteni duhan; 2 dana uskladišteni zrnati poljoprivredni proizvodi (Magtoxin pelete).

\subsection{Mikrobiološki insekticidi}

\subsubsection{Bacillus thuringiensis}

Djeluje na gusjenice mladih stadija (I-III) kukuruznog moljca, gubara, dudovca, metlice, jabučnog moljca, kupusnog bijelca, grozdovih moljaca, maslinovog moljca, topolovog prelca, topolovog gubara i borovog četnjaka. Djeluju sporo te se trebaju primijeniti dovoljno rano da ne dođe do šteta. Ne uništavaju korisne insekte. Bezopasni su za pčele i dopušteni u ekološkoj i integriranoj proizvodnji.

$\mathrm{LD}_{50}>5000$.

\subsubsection{Cydia pomonella granulovirus}

Biološki insekticid namijenjen za suzbijanje jabučnog savijača (Cydia pomonella). Aktivna materija je Cydia pomonella granulovirus u količini 1,5 x 1013 granula po litri. Nakon tretmana gusenice jabučnog savijača uginjavaju za 3-5 dana. Madex se koristi posebno za suzbijanje prve generacije jabučnog savijača. K (Carpovirusine Evo 2) - 3 dana sve dozvoljene kulture. Madex i Granupom smiju se koristiti do 6 puta godišnje, a Carpovirusine Evo 2 do 10 puta godišnje.

\subsection{Dijatomejska zemlja}

Kod insekata uzrokuje oštećenja kutikule, zbog čega dolazi do gubitka vode iz organizma te uginuća. Djeluje samo na štetnike izvan zrna. 


\section{AKARICIDI}

\subsection{Abamektin}

Akaricid i insekticid kontaktnog i želučanog djelovanja. U biljci se kreće translaminarno. Prirodni proizvod zemljišne aktinomicete Streptomyces avermitilis. Visoko toksičan za akvatične organizme i pčele. Odlično djeluje na crvenog voćnog pauka i običnu kruškinu buhu. Štetnici koji dođu u kontakt s ovom djelatnom tvari ili je unesu hranom u organizam postaju nepokretni i za 2-4 dana uginu. Za to vrijeme se ne hrane i ne uzrokuju štete. Prikladan u integriranoj proizvodnji voća jer vrlo slabo utječe na populaciju korisnih insekata u nasadima voća. Pod utjecajem svjetlosti djelatna tvar se na listu vrlo brzo razgradi tako da ima samo kratkotrajno kontaktno djelovanje na korisne vrste. Najbolji rezultati u primjeni ovog pripravka dobiju se ranijom primjenom, početkom vegetacije i razvoja populacije štetnika. Prskanje treba obaviti kada se izlegne od 30-50\% jajašaca crvenog voćnog pauka.

Pripravak: Vertimec 018 EC, Kraft 18 EC, Vertimec Pro, Apache.

\subsection{Heksitiazoks}

Heksitiazoks je akaricid inhibitor razvoja grinja. Primjenjuje se u voćkama za suzbijanje koprivinih grinja i crvenog pauka. Sredstvo treba primjeniti na početku izlaska ličinki iz zimskih jaja, prije pojave odraslih stadija grinje.

$\mathrm{LD}_{50}>5000$.

\subsection{Etoksazol}

Etoksazol je akaricid koji je visoko toksičan za jaja i juvenilne stadije grinja (fam. Tetranychidae). Za odrasle jedinke nije toksičan, ali značajno reducira fertilitet tretiranih ženki. Na osnovu simptoma koje izaziva etoksazol se svrstava u akaricide inhibitore razvoja, zajedno sa klofentezinom i heksitiazoksom.

\subsection{Fenazakin}

Kontaktnog, snažnog početnog i dugotrajnog djelovanja protiv crvenog voćnog pauka, lozine i koprivine grinje. Djelatna tvar ometa disanje svih pokretnih oblika grinja. Ovicidno djeluje i na ljetna jaja. Uporaba: u voćnjacima jabuka i krušaka te vinogradima.

$\mathrm{LD}_{50}$ - 134. S.O. - III (do $20 \%$ djelatne tvari), inače - II.

\subsection{Klofentezin}

Suzbija zimska i ljetna jajašca crvenog pauka. Ima kontaktno i dugo rezidualno djelovanje. $\mathrm{LD}_{50}$ - 3200. S.O. - III. 


\subsection{Spirodiklofen}

Kontaktni akaricid. Ima dozvolu za suzbijanje pokretnih razvojnih oblika štetnih grinja s popratnim ovicidnim djelovanjem. Primjenjuje se rano u proljeće u vrijeme masovnog izlaska ličinki iz jaja i njihovog naseljavanja na listove. Moguće ga je upotrebljavati u punoj cvatnji jer je potpuno neškodljiv za pčele. Ne iskazuje unakrsnu rezistentnost s drugim akaricidima.

S.O - III. $\mathrm{LD}_{50}-2500$. T-1 jabuka, grožđe.

\subsection{Tebufenpirad}

Suzbija zimska i ljetna jajašca crvenog pauka. Ima kontaktno i dugo rezidualno djelovanje. $\mathrm{LD}_{50}$ - 3200. S.O. - III.

\subsection{Piriproksifen}

Aktivna tvar piriproksifen pripada grupi inhibitora presvlačenja koji inhibira rast insekata, spriječava embriogenezu odnosno inhibira procese, metamorfoze i reprodukcije. Posjeduje kontaktno i digestivno djelovanje i ovicidno djelovanje.

\subsection{Ciflumetofen}

Aktivna tvar ciflumetofen razvrstan je u IRAC grupu 25A. Inhibira prijenos elektrona kompleksa II u mitohondrijima, čime se zaustavlja proizvodnja ATP, što dovodi do paralize i smrti grinja. Ciflumetofen je visokoselektivan zbog svog načina djelovanja. Primjenjuje se od otvaranja prvog lista do zriobe.

$\mathrm{LD}_{50}>5000$.

\section{NEMATOCIDI}

Koriste se injektiranjem u tlo, zalijevanjem tla, inkorporacijom u tlo ili fumigacijom tla, no bez obzira na njihovu formulaciju, kada dospiju u tlo, svi djeluju kao fumiganti. Kod većine je određen rok koji mora proći između primjene i sjetve, odnosno sadnje. $\mathrm{K}$ - za dazomet za povrće je 42 dana, a za ukrasno bilje se određuje biološkim testom fitotoksičnosti.

Dazomet se u tlu pretvara u metilizotiocijanat (metifum). Dazomet je nematocid, insekticid, fungicid i herbicid.

$\mathrm{LD}_{50}$ - 520. S. O. - III. T - 0,05 voće i povrće; 0,2 kupusnjače.

\subsection{Dazomet}

Ne raditi na previsokim temperaturama jer je tada oslobađanje aktivnog plina prebrzo, a dezinfekcija nepotpuna. Optimalna temperatura tla za primjenu je 10-15o C. Tlo treba dobro usitniti nekoliko dana prije dezinfekcije. Nakon rasipanja sredstvo odmah unijeti u tlo na dubinu 
od 5-25 cm. Održavati vlažnost tla u narednih pet dana. Nakon dezinfekcije obavezno prozračiti tlo prije sjetve ili sadnje. Dozvoljena je jedna primjena svake 3 godine.

S.O. - III.

\subsection{Fostiazat}

Rezidualni sistemični insekto-nematocid. U krumpiru se koristi uz obaveznu inkorporaciju u tlo $(10-15 \mathrm{~cm})$.

$$
\mathrm{LD}_{50}-57 .
$$

\subsection{Oksamil}

Oksamil je nematocid i insekticid sa kontaktnim i sistemičnim djelovanjem, efikasan u suzbijanju nematoda i bijele leptiraste uši na usjevu paprike i krastavca u zaštićenom prostoru. Aktivna tvar oksamil je inhibitor kolinesteraze iz grupe karbamata. Kada se primjenjuje kroz sustav za navodnjavanje kap po kap, usvaja se korijenom i translocira kroz biljku.

$\mathrm{LD}_{50}$ - 37. S.O. = II. Uzgoj salate dozvoljen tek nakon 42 dana.

\subsection{Fluopiram}

Koristi se prvenstveno kao nematocid, a ima i fungicidni učinak na uzročnika pepelnice.

Više količine i dvije primjene preporučljivi su u uvjetima jačeg ili jakog napada nematoda. Primjena u sjemenskim usjevima nije dozvoljena.

\section{LIMACIDI}

Limacidi su pripravci namijenjeni suzbijanju puževa. Koriste se u obliku zatrovanih mamaca koji se rasipaju po tlu uz biljke.

\subsection{Metaldehid}

$$
\mathrm{LD}_{50} \text { - 380. S.O - III. }
$$

Karenca -21 dan lisnato povrće, mahunasto povrće, korijenasto povrće, voćnjaci, vinova loza, jagoda (Pužocid, Pužomor); 14 dana plodovito povrće, jagoda (Gardene). Na tretiranu površinu ne puštati perad 7 dana.

\section{2. Željezo (III) pirofosfat}

Željezo (III) pirofosfat pelete koriste se u ekološkoj poljoprivrednoj proizvodnji za suzbijanje štetnih vrsta puževa. Proizvod je neotrovan, te nije razvrstan u grupe otrova. Nakon hranidbe s peletama željeznog (III) pirofosfata puževi se prestaju hraniti i postupno dehidriraju. Pelete je uputno postaviti u posude kao mamce. Sadržaj u posudama nije u direktnom kontaktu s biljkom 
niti sa tlom, te nema negativnog djelovanja niti opasnosti za ptice i kućne ljubimce.

Uporaba pripravka prije početka razvoja kultura je moguća pomoću raspršivača gnojiva. Pripravak ne treba raspršivati direktno po biljkama. Pripravak ne šteti kišnim glistama, ježevima, domaćim životinjama te ostalim životinjama i kukcima.

\section{KORVIFUGI}

Korvifugi su pripravci namijenjeni za odbijanje napada ptica (vrane, golubovi, fazani). Koriste se nanošenjem na sjeme koga štite svojim, za ptice, odbijajućim karakterističnim neprijatnim mirisom i okusom.

\subsection{Metiokarb}

Pripravak namijenjen suzbijanju žičnjaka. Ima i repelentno djelovanje na ptice.

Pripravak: Mesurol FS 500.

\subsection{Ciram}

Repelent namijenjen odbijanju ptica od ishrane sjemenom kukuruza nakon sjetve.

\section{REGULATORI RASTA I FIZIOTROPI}

\subsection{Etefon}

Pod utjecajem biljnog soka oslobađa etilen. Sistemični fiziotrop/regulator rasta, kratke perzistentnosti. Koristi se za ubrzavanje zriobe i lakšu berbu plodova višnje i za ujednačavanje zriobe plodova rajčice.

$$
\mathrm{LD}_{50} \text { - 4229. S.O. - III. }
$$

\subsection{Klormekvat}

Djeluje kao inhibitor sinteze giberelina. Spriječava polijeganje žitarica i stimulira rast korijena. U ozimoj pšenici se primjenjuje od početka busanja do prije pojave drugog koljenca (fenofaza 21-31 po ZCK). Tijekom ovog perioda može se primijeniti i u dvije odvojene doze: 1,6 $+0,6$ l/ha. U ozimom ječmu se može primijeniti prije pojave 4 izdanka u proljeće ili u dozi 0,6 $1 /$ ha u jesen i 1,6 1/ha u proljeće prije pojave prvog koljenca. $U$ jaroj pšenici se primjenjuje $u$ fenofazama 21-29 ili od početka do kraja busanja. U ozimoj raži se primjenjuje od početka vlatanja do formiranja zastavice. 
U ozimoj i jaroj zobi primjenjuje se od početka vlatanja do pojave trećeg koljenca. U tritikali se primjenjuje u fazi od punog busanja do prije pojave prvog koljenca. U cvjećarstvu se rabi radi boljeg razvoja cvjetnih grančica.

LD $_{50}$ 807-966. S.O - III.

\subsection{Klorprofam}

Spriječava klijanje konzumnog krumpira u tijeku skladištenja. Djelatna tvar smanjuje intenzitet disanja gomolja te ih tako štiti od gubitka vlage i hranjivih tvari. Tek nakon provjetravanja može se $u$ isto skladište pohraniti sjemenski krumpir i druga sjemenska roba.

$\mathrm{LD}_{50}$ - 5000. S.O. - III.

\subsection{Maleinski hidrazid}

Upotrebljava se za spriječavanje rasta zaperaka duhana i sprečavanje klijanja luka.

Tretira se kada je većina biljaka u fenofazi pune cvatnje, dan nakon zakidanja zaperaka.

$\mathrm{LD}_{50}$ - 2340. S.O. - III. K - OVP za duhan.

\section{5. Proheksadion}

Rabi se za skraćivanje mladica jabuke kada iste dosegnu duljinu od 5-10 cm.

$\mathrm{LD}_{50}>$ 5000. S.O. - III. K - 55 dana. Karenca - OVP.

\section{6. Trineksapak}

Skraćuje vlati i spriječava polijeganje. Povećava masu korijena. Djeluje kao inhibitor sinteze giberelina. U pšenici od faze 31-37 po ZCK, jarom ječmu 33-37 po ZCK, ozimom ječmu i raži 31-37 po ZCK, ozimoj tritikali 32-37 po ZCK i zobi od 31-34 po ZCK.

LD $_{50}$ 4460. S.O. - III. K - OVP. (Moxa, Next).

\section{7. Indolilbutanska kiselina}

Stimulator rasta, koristi se za poticanje formiranja korijena kod reznica ukrasnog bilja.

\section{8. 1-dekanol}

Regulator rasta koji se koristi za sprječavanje rasta zaperaka na duhanu.

\section{9. 1-metilciklopropen}

Koristi se kao regulator rasta za očuvanje kakvoće plodova nakon berbe. 


\section{10. Giberelini}

Biljni hormoni koji se koriste za poticanje zametanja i razvoja plodova te poboljšanje kvalitete kožice ploda.

\section{11. Etilen}

Etilen djeluje kao biljni hormon te stimulira dozrijevanje plodova.

\section{12. Natrijevi nitrofenolati}

Regulatori rasta koji povećavaju kvalitetu i urod

\section{OSTALA SREDSTVA}

\subsection{Benzojeva kiselina}

Dezinficijens širokog spektra. Spriječava prijenos gljivica, virusa, bakterija i viroida. $\mathrm{LD}_{50}$ - 2000. S.O. - III.

\subsection{Vapno}

Dezinficijens širokog spektra. Spriječava prijenos gljivica, virusa, bakterija i viroida. $\mathrm{LD}_{50}$ - 2000. S.O. - III.

\section{OKVAŠIVAČI}

Okvašivači su sredstva koja se dodaju kod prskanja ili raspršivanja različitih pesticidnih pripravaka kontaktnog djelovanja u cilju smanjenja površinske napetosti, čime se postiže bolje vlaženje biljnih dijelova, kao i za povećanje sposobnosti prijanjanja pripravka za tretiranu biljku ili insekta. Koriste se prilikom suzbijanja pepelnice na jabuci, plamenjače luka, kod tretiranja kultura i insekata s naglašenom voštanom prevlakom (repe, kupusnjače i druge) i folijarnih herbicida. Uporabom ovih tvari može se smanjiti doza pripravku uz kojeg se koristi za 15-20\%.

\section{ATRAKTANTI}

Tvari koje se koriste za privlačenje štetnih kukaca zbog ometanja parenja ili ciljanog suzbijanja. 